\title{
O CONSENTIMENTO DO OFENDIDO À LUZ DA TEORIA DA IMPUTAÇÃO OBJETIVA
}

\author{
Heloizu Meroto de Luca”
}

\begin{abstract}
Resumo:
Este trabalho analisa o consentimento do ofendido em Direito Penal. sob a perspectiva da teoria da imputação objetiva. É dividido em quatro partes. A primeira compreende um estudo do consentimento, com destaque para as suas conseqüências penais (teorias monista e dualista). A segunda estuda a teoria da imputação objetiva através de seus principais autores: Roxin, Jescheck e Jakobs. Na terceira partc tumse um panorama de como o consentimento é tido por cada um deles, bem como pelo Direito Penal brasileiro. A última parte propõe uma nova visão do instituto, sugundo a teoria da imputação objetiva, com vistas à sua flexibilização e adequação à sociedade de risco atual.
\end{abstract}

Palavras-chave: Consentimento. Ofendido. Vitima. Imputação objetiva. Direito Penal.

\begin{abstract}
:
This work analyses the consent of offended in Criminal Law, concerning the objective imputation doctrins. It is divided into four parts. The first one is a study about consent, enhancing criminal consequences (monist and dualist doctrines). The second part is a study about the objective imputation doctrine, according most important scholars: Roxin, Jescheck and Jakobs. In the third part, a landscape of how consent is treated by each author and how this subject is treated in Brazilian Criminal law. The last part this work suggests a new vision for this doctrine. concerning the objective imputation theory, pointing out its flexibility and adjustment to the contemporaneous risk society.
\end{abstract}

Keywords: Consent. Offended. Victim. Objective Imputation Doctrine. Criminal Law.

\section{Introdução}

Em seus primórdios, a punição penal identificava-se à vingança privada, sendo a própria vítima ou seus familiares os responsáveis pela aplicação da pena. Mais tarde, com o desenvolvimento do Direito Penal, o crime foi entendido como a conduta que

Monografia desenvolvida sob orientação do professor titular Antònio Luis Chaves Camargo, ganhadora du prêmio de melhor "T cse de Láurea de 2004" do Departamento de Direito Penal. Medicina Forense e Criminologia.

*" Bacharel cm Direito, assessora da Procuradoria Regional da República da 3" Região. 
lesa não apenas a vítima. mas toda a sociedade, passando o Estado a monopolizar tanto o processo quanto esta forma de punição.

A tecnicização do Direito Penal retirou a importância da vítima, que passou a ocupar posição secundária na teoria do delito, atribuindo ao agente todas as atenções, scjam elas dogmáticas nos campos penal e processual penal - ou político-criminais. $\mathrm{O}$ próprio termo agente pressupõe a passividade da vitima, pois considera que enquanto o autor atua, ela permanece inerte, recebendo a ação do primeiro. Não há lugar para interação entre o autor $\iota \mathrm{o}$ ofendido.

Nos últimos anos, contudo, tem-se verificado uma redescobertal da vitima, que aos poucos sai da zona cinzenta para influir no Direito Penal. Esta redescoberta deuse quando uma parte da Criminologia dedicou-se a atribuir maior relevância à vítima, especialmente no tocante ao estabelecimento de novos mecanismos de reparação dos danos por ela sofridos. Tais estudos culminaram em uma nova ciência: a Vitimologia, que exerceu grande influência na dogmática penal, gerando a Vitimodogmática, ${ }^{2}$ responsável pelo estudo da responsabilidade recíproca que ocorre entre o agente e a vítima.

A Vitimodogmática apresenta-se ao Dircito Penal como um de scus ramos autônomos, embora conexa a este último, fundamentando-se na política criminal para defender a maior participação do ofendido, buscando na dogmática jurídica suas formas de atuação. Estuda a valoração da possivel incidência do comportamento da vítima na determinação da responsabilidade penal do autor, e parte do pressuposto de que ela não apresenta uma posição passiva frente ao crime, podendo até mesmo concorrer com o agente para a caracterização delitiva. Procura examinar sua influência ou a sua participação para caracterização típica, bem como para a atenuação da responsabilidade penal do agente. Trata-se de uma nova perspectiva na discussão doutrinária penal.

A Vitimodogmática é regida pelo princípio vitimológico, segundo o qual a tutela penal of erecida pelo Estado não é apropriada aos casos cm que a vítima não merece ou não necessita de proteção, devendo, portanto, ser eliminada. O fundamento do princípio é o de que o Direito Penal deve proteger os bens jurídicos de forma proporcional, e isso tanto em relação ao agente quanto ao ofendido. Para que o autor responda penalmente pela sua conduta, é necessário que exista uma correspondência entre a necessidade de sua punição e a necessidade de proteção da vítima. ${ }^{3}$

Com a Vitimodogmática, as próprias definiçōes de autor, vítima e até mesmo de delito perdem seu sentido clássico, pois é a vítima quem decide o qué é o que

1 CANCIO MEI IÁ, M. Reflexiones sobre la "victimodogmatica" en la teoria del delito. Revista Brasileira de Ciências Criminais. São Paulo. v. 7. n. 25. jan./mar. 1999. p. 24, fala em um redescubrimientu da vitima pelas ciências penais.

2 Id.. ibid., p. 24-25.

3 Id.. ibid.. p. 39-40. 
não é delito no caso concreto. Esta visão implica certa privatização ou desestatização dos meios de imputação e persecução penais, em uma intenção abolicionista do Direito Penal. ${ }^{4}$

O consentimento encontra-se inserido na ciência da Vitimodogmática, pois tem a ver com a participação do ofendido que, mediante a manifestação de sua vontade. permite a ingerência por terceiros em seus bens juridicamente relevantes, muitos dos quais penalmente protegidos. Se o ofendido autoriza esta ingerência por outrem, então a responsabilidade penal do último deve ser diminuída ao excluída, pois o primeiro incrementou seu próprio risco.

O estudo do consentimento é interessante ao Direito Penal, pois significa a análise da teoria do delito sob a perspectiva da atuação do ofendido, e parte do pressuposto de que autor e vítima se inter-relacionam, através de seu agir comunicativo, para a prática delitiva. Isso permite que a responsabilidade penal do agente possa ser diminuída ou até mesmo excluída, tudo dependendo do comportamento do ofendido. Mais que uma nova perspectiva dogmática ou uma necessidade político-criminal, a influência do consentimento à teoria do delito é uma questão constitucional, pois se baseia na dignidade da pessoa humana, presente no art. $1^{\circ}$ inciso III da Constituição Federal brasileira, fundamento mesmo do Estado Democrático de Direito.

A história do consentimento no Direito Penal remonta da passagem do Digesto de Ulpiano (D. 47. 10 de iniur. 1.1 \$) nulla iniuria est quae in volentem fiat "o que se faz com a vontade do lesado não constitui injusto" -, que ficou conhecida com o aforismo juridico volenti non fit iniuria. Este princípio significava que o consentimento era causa justificante para todos os tipos de iniuria. ou seja, para os delitos da personalidade, incluindo-se aí aqueles que atentavam contra a vida e a integridade física da pessoa, por se entender que tais bens apresentavam natureza individual. A máxima apresentava limites, sendo aplicada somente em relação aos direitos que se entendiam subjetivos, estando impedida nos delitos que atentavam contra a ordem comum. ${ }^{5}$

Atualmente, no Direito Penal brasileiro, a eficácia do consentimento é considerada apenas por alguns poucos autorss, que o colocam ora como elemento excludente do lipo, ora como elemento supralegal de justificação. A formação positivista dos doutrinadores brasileiros faz com que eles não atribuam a devida importância ao instituto, pois a matéria não se encontra normatizada, limitando sua eficácia a alguns poucos bens, em muito estreitando sua atuação sobre os diferentes tipos penais.

4 CANCIO MELIÁ, M. Reflexiones sobre la "victimodogmatica" en la teoria del delito. Revista Brasileira de Ciências Criminais, São Paulo, v. 7, n. 25. jan.ı mar. 1999. p. 35.

Cf. JESCHECH, H.-H. Tralado de derecho penal: parte general. Barcelona: Bosch, 1981. p. 515, e ROXIN,

C. Derecho penal: parte general. Madrid: Civitas, 2001. p. $511-512$. 
Daí a enorme relevância do estudo do consentimento do ofendido tanto no contexto penal mundial, que vem progressivamente se libertando da indisponibilidade dos buns penais e de seu estigma exclusivamente social, quanto no contexto do Direito Penal brasileiro, que, pela adoção de teorias e técnicas inadıquadas, não acompanha a evolução da sociedade moderna, fechando os olhos para as garantias constitucionalmente asseguradas, como a dignidade da pessoa humana.

O primeiro capítulo do presente trabalho estuda o instituto do consentimento do ofendido em seus vários aspectos. Seu item 2.1 conceitua o consentimento, fazendo a distinção entre o consentimento que exclui o tipo (consentimento-atipicidade), e o consentimento que exclui a antijuridicidade (consentimento-justificação), e apresentando suas primeiras implicações no Direito Penal. O item 2.2 determina a natureza do consentimento do ofendido, além de traçar seus requisitos de existìncia, validade e eficácia. O item 2.3 trata sobre o consentimento presumido. $\mathrm{O}$ item 2.4 aborda o consentimento ex post (outorgado somente após a prática da conduta do agente), diferenciando-o tanto do perdão do ofendido quanto do perdão judicial. Já o item 2.5 trata dos casos de revogação do consentimento pelo ofendido.

$O$ item 2.6 estuda as conseqüências penais do consentimento. Este item é dividido em três subitens. O primeiro (2.6.1) apresenta o paradigma dualista, que divide o consentimento em acordo (que exclui o tipo) e em consentimento (que exclui a antijuridicidade). Já o segundo (2.6.2) apresenta o paradigma monista, para o qual o consentimento implica sempre em exclusão da tipicidade. Ao final. são tecidas as principais críticas aos métodos apresentados, bem como a sua contribuição para a eficácia penal do consentimento.

O terceiro e último subitem (2.6.3), a partir das conclusões dos subitens anteriores, propõe um novo paradigma dualista, por se adequar melhor aos preceitos da teoria da imputação objutiva, com a divisão do consentimento em um consentimentoatipicidade (que exclui o tipo) e em um consentimento-justificação (que exclui a antijuridicidade), no qual o primeiro tem lugar nos tipos que asseguram a liherdade de disposição de bens pelo individuo, e o segundo tem lugar nos tipos que asseguram os bens em espécie.

Por fim, no item 2.7 há a análise da eficácia e do tratamento dogmático do consentimento do ofendido no Direito Penal brasileiro, através do estudo das teorias dos principais doutrinadores nacionais.

O segundo capítulo trata da teoria da imputação objetiva, bem como de sua importância ao consentimento. O estudo desta teoria é extremamente importante ao 
desenvolvimento do Direito Penal, sobrctudo do brasileiro, que reclama por novas formas de interpretação das normas penais.

A partir da década de 90 , o Brasil tem observado um crescente aumento em sua criminalidade, e isso devido a dois fatores principais, quais sejam: i) a origem e/ou o aumento de crimes que atentam contra bens difusos e coletivos, tais como os crimes relativos ao tráfico de entorpecentes (definidos na Lei n. 6.368/76), que afetam a saúde pública, os crimes ambientais (definidos na Lei n. 9605/98), que atentam contra o meio ambiente. e inúmeros outros; e b) a ineficácia das normas penais vigentes, que não conseguem reprimir a criminalidade contemporânea. Diante disso, a sociedade, imbuída em um forte sentimento de injustiça e impunidade, reclama providencias ao Estado, que responde através da elaboração de novas normas penais, caracterizadas pelo rigor das penas impostas, pela falta de técnica legislativa e principalmente pela afronta aos princípios básicos de Direito Penal.

Como as anteriores, estas novas leis não conseguem ser aplicadas frente à criminalidade moderna, acabando por colocar em risco não apenas a legitimidade do Direito Penal, mas também a de todo o Estado, na medida em que o primeiro tem por função manter o status quo e os valores da sociedade e, com isso, permitir a atuação do segundo. Por conseqüência, tem-se a formação do chamado Direito Penal simhólico, no qual os tipos penais têm por única função cessar os clamores sociais, como resposta à criminalidade complexa na sociedade de risco.

Esta ineficácia das normas penais brasileiras ocorre principalmente devido à impropriedade do método utilizado em sua interpretação. () tecnicismo jurídico de base positivista, atualmente vigente no Brasil, consigna um sistema penal fechado c axiológico, dedutível através do raciocínio lógico-formal, em estrita observância às normas juridicas positivadas, que postulam verdades absolutas e apriorísticas. É bem verdade que, nas últimas décadas, a doutrina brasileira adotou certa postura finalista, permitindo a discussão sobre a finalidade da conduta do agente e, na medida do possivel, sobre alguns elementos valorativos, quando da imputação penal. Entretanto, forte é a influência do positivismo juridico e do neokantismo, que buscam a resolução de conflitos através da interpretação restritiva da norma e da jurisprudência de interesses. ${ }^{\circ}$

A teoria da imputação objetiva é essencialmente relevante ao Direito Penal brasileiro, pois entende que toda conduta apresenta um significado no seio social, depreendido através do agir comunicativo de seus integrantes. Assim, a conduta só poderá ser atribuída ao agente se criar um desarranjo na sociedade, desestruturando-a. Este

6 CAMargo, A. L. Chaves. Imputaçâo Objetiva e Direito Penal Brasileiro. São Paulo: Cultural Paulista. 2001. p. 117-120. 
desarranjo ocorre quando ela cria um risco acima daquele socialmente permitido, ou seja, do risco previsível ou até mesmo quisto nas relações entre os atores sociais.

A análise do risco socialmente permitido como requisito de imputação permite o estudo dos casos em que o risco é incrementado pela própria vítima, com a sua conseqüente responsabilização c a diminuição ou extinção da responsabilidade penal do agente. A principal forma de autocolocação em perigo da vítima ocorre através do seu consentimento. Daí a necessidade de se estudar o consentimento do ofendido à luz da teoria da imputação objetiva, pois somente ela permite uma análise aprofundada deste instituto, alargando seu campo de eficácia para atingir tipos que não seriam possíveis pela doutrina positivista de influência neokantiana.

Por não se encontrar normatizado, o consentimento do ofendido tem sua eficácia restrita em nosso Direito Penal. Os doutrinadores brasileiros, por sua formação positivista, em muito limitam seu âmbito de eficácia, restringindo-o a uma pequena gama de bens que rotulam aprioristicamente como "disponíveis" Mesmo em relação a estes. o consentimento só é eficaz em alguns poucos casos pré-determinados. Há inclusive autores, como Nelson Hungria, ' que não atribuem qualquer efeito ao consentimento, por entenderem que o Direito Penal tutela tão somente bens de natureza social, indisponíveis.

Neste segundo capítulo se estuda a imputação objetiva, tendo-se em vista sua relevância ao Direito Penal brasileiro, em especial ao consentimento do ofendido. Seus itens 3.1 a 3.4 apresentam uma análise crítica das teorias de imputação que antecederam a teoria da imputação objctiva: o item 3.1 cuida do causalismo, o item 3.2 cuida da teoria da causalidade adequada, o item 3.3 cuida da teoria da relevância e o item 3.4 cuida da adequação social. A análise destas teorias é importante para que sejam tecidas as suas principais críticas e as inovações trazidas pela imputação objetiva ao Direito Penal.

O item 3.5 traça a evolução da teoria da imputação objetiva desde a sua criação até os dias de hoje. Já o item 3.6 apresenta as principais teorias da imputação objetiva: a teoria de Roxin (subitem 3.6.1), a teoria de Jescheck (subitem 3.6.2) e a teoria de Jakobs (subitem 3.6.3).

O quarto capítulo compreende o consentimento sob o enfoque da teoria da imputação objetiva. Começa por analisá-lo segundo cada um dos autores citados, que, juntos, são seus maiores expoentes: a teoria do consentimento segundo Roxin (item 4.1), segundo Jescheck (item 4.2) e segundo Jakobs (item 4.3). O item 4.4, a partir das conclusões obtidas durante todo o trabalho, lança uma nova visão do consentimento à luz

TOLEDO. F. A. Principios Básicos de Direito Penal. São Paulo: Saraiva, 2000. p. 172. 
da teoria da imputação objetiva, alargando seu âmbito de eficácia e amoldando-o aos valores vigentes na sociedade atual.

Por fim, no quinto capítulo, apresentam-se as principais conclusões ohtidas durante todo o trabalho.

\section{Consentimento do ofendido}

\subsection{Conceito}

O consentimento do ofendido é a autorização manifesta, pelo portador de bens jurídicos de elevada importância, para que outrem realize uma ingerência nestes bens, gerando efcitos no âmbito do Direito Penal. É a principal expressão da liberdade $e$ da autonomia individual e encontra-se fundamentado na dignidade da pessoa humana, que pode ser definida como a capacidade de autodeterminação da pessoa segundo a sua vontade. Por certo, a dignidade da pessoa humana constitui um dos fundamentos do Estado Democrático de Direito, motivo pelo qual se encontra na Constituição de inúmeros Estados, incluindo-se a brasileira, em seu art. $1^{\circ}$ inciso III. Daí a enorme relevância do consentimento, capaz de interferir até mesmo na esfera jurídico-penal, protetora de bens públicos por natureza.

Embora o consentimento esteja fundamentado na dignidade da pessoa humana e, conseqüentemente, na capacidade de autodeterminação da pessoa segundo a sua vontade, ele não pressupõc a vontade em si, mas antes a sua exteriorização. O Direito Penal requer sempre uma inter-relação entre os individuos, ou seja, entrc os agentes sociais, a qual se dá através da comunicação (verbal, escrita, comportamental, entre outras). Para que determinada vontade scja considerada pelo Direito Penal é necessário que ela faça parte deste "agir comunicativo", ou seja, que ela seja externada (implícita ou explicitamente, em momento anterior ou posterior à ação) aos agentes que se interrelacionam durante a ação delitiva. A mera vontade interna, sem qualquer forma de exteriorização no mundo fático, não pode ser tida como consentimento, pois é irrelevante ao Direito Penal.

Molina Arrubla fala em um consentimento do agente delitivo (ofensor), referindo-se a sua vontade de praticar a conduta, que, posteriormente, é reprovada pelo Direito Penal." Entretanto, a equiparação do consentimento à vontade do ofensor faz-se

8 "En efecto, si bien en un principio pudiera decirse que de alguna manera los numerosos expositores de las ramas jurídicas penales se han encargado y ocupado. asi sea de manera meramente tangencial, del consentimiento del sujeto activo de la infracción, en cuanto hace con su voluntaric dad de ánimo reterido a la conducta que ulteriormente le es reprochada de manera especifica por el aparato jurisdiccional del 
ainda mass imprópria do que a equiparação do consentimento à vontade da vítima. Isso porque, alím da impropriedade de assemelhar o consentimentu à vontade, tal designação contraria a natureza do consentimento penal, que é scmpre reservado à vítima, pois ela é a única que pode autorizar a ingerência de terceiros sobre seus bens jurídicos.

O consentimento envolve também a auto-responsabilidade da vítima. Ś a pessoa apresenta a capacidade de autodeterminar-se segundo sua vontade, cntão cla tem certa capacidade de escolher quais bens juridicos podem ser preservados e quais podem ser descartados, ou lesados. A vítima deve responsabilizar-se pelos eventuais danos ou prcjuizos advindos di condula do olensor. se eles decorrerem da expressão de sua autonomia.

Por outro lado, o consentimentu do ofendido implica a diminuição ou a cxclusão ${ }^{9}$ da responsabilidade penal do agunte delitivo. Sc a vítima permitiu a ingerência de outrem ao bem juridico relevante, então o Estado não poderá punir o agente com a mesma intensidade que o faria caso não houvesse consentimento. Disso decorre que a cficácia do consentimento acarreta, ao mesmo tempo, a auto-rcsponsahilidade da vítima e a não responsabilidade penal do agente.

O consentimento pode ser de dois tipos: i) consentimento-atipicidade; e ii) consentimento-justificação. O consentimento-atipicidade é o exercício, pelo ofendido, da liberdade de disposição de bens juridicamente relevantes. liberdade esta que se encuntra assegurada em determinados lipos penais. () consentimento-atipicidade só se manifesta nos tipos que assiguram esta liburdade de disposição de bens pelo individuo, sendo responsável por excluir a tipicidade da conduta.

Assim ocorre no lipo de furto (art. 155 do CP): se A doa para B determinado objeto que não utiliza, exercendo sua liberdade de disposição sobre a propricdade do hem, então sua conduta exclui a tipicidade, pois o tipo de furto tutela exatamente a liberdade de disposição da propriedade pelo portador do bem juridico. O mesmo ocorre no delito de estupro (art. 213 do CP): se C, mulher, deseja manter relações carnais com D, homem, então a conduta não será típica. pois C, através de seu

Estado, sobre la base del reproche genérico anticipadamente elaborado por el Legislador, pudiéndos: conjugar en tal categoria ontológica tanto al Legislador ordinario como al extraordinario, en tanto su actuar delictual es sometido a un riguroso análisis dentro de la 'Teoria de la Acción' en materia delictual. como que en ella se distínguen el acto humano y el acto del hombre, asi como en la 'Teoria di la Culpabilidad', cuando se distinguen si ese actuar fué intencional, mcramente culposo o puramentc ultraintencional; la verdad es que proporcionalmente poco se ha dicho en tratándose del consentimiento del sujeto pasivo de la infracción. vale decir, de la victima. con respecto a la comisión de la conducta antisucial, y la consecuente perpetración de un verdadero hecho punible." (grifos nossos) El consentimiento del sujuto pasivo de la infraccion a la ley penal, in Revista d. la Facultad de Dirciho y Ciincias Politicas da Universidad Pontificia Bolivariana, Medellin, 11. 75, p. 13-14, out./dez. 1986.

9 Cf. art. 59, caput, do Código Penal Brasileiro. 
consentimento, permitiu a ingerûncia de $\mathrm{D}$ em sua intimidade. Ressalte-se que o tipo protege a liberdade de disposição, pela mulher, de sua intimidade, ou, em outras palavras, sua liberdade sexual.

O consentimento-atipicidade ainda tem lugar no tipo de perigo de contágio de moléstia grave (art. 131 do $C P$ ): se $E$ pratica relações sexuais com $F$ sem o uso de preservativo, então a possivel transmissão de AIDS a um dos parceiros não será típica, vez que eles consentiram tacitamente sobre a ingerência em suas vida e saúde, tendo-se em vista que o tipo protege a liberdade sobre a disposição destes bens.

O consentimento-justificação, por sua vez, é a renúncia, enquanto vontade externada pelo ofendido, à proteção penal dos bens jurídicos oferccida pelo Estado, c se manifesta somente nos tipos que apresentam o dissenso entre ofensor c vítima como seu elemento integrante. O tipo de homicidio (art. 121, caput, do CP) prescreve: "Matar alguém" Sc E desfere um tiro em F mediante seu consentimento, sobrevindo sua morte, então E pode ou não ser imputado pela morte de F. tudo dependendo de fatores como o estado de conservação do bem. a finalidade da lesão, dentre outros, analisados no caso em concreto.

Se E desferiu o tiro para extinguir o sofrimento da vítima, causado por uma terrível doença que já vinha se prolongando há anos, então o consentimento será eficaz, excluindo a antijuridicidade da conduta. Todavia, se $\mathrm{E}$ desferiu o tiro porque $\mathrm{F}$ queria que seus herdeiros recebessem seu seguro de vida, então o consentimunto não será eficaz, não sendo hábil a excluir a antijuridicidade da conduta. A eficácia do consentimentojustificação deve ser analisada caso a caso pelo magistrado.

O mesmo ocorre no crime de lesão corporal gravissima (art. $129, \S 2^{\circ}$ do CP). Se $\mathrm{G}$ amputou a mão de $\mathrm{H}$ mediante seu consentimento porque o último apresentava uma grave moléstia no membro, então G não será imputado pela lesão corporal. Diverso será se $G$ amputou a mão de $\mathrm{H}$ mediante seu consentimento porque o último furtou $\mathrm{R} \$ 50$ (cinqüenta reais) do primeiro, pois a conduta lesiva não será justificada. e G será imputado pela lesão.

Portanto, o consentimento do ofendido pode ser conceituado como a autorização manifesta, pelo portador de bens jurídicos de clevada importância, para que outrem realize uma ingerência nestes bens, em efetiva consonância ao princípio da dignidade da pessoa humana, apresuntando por conseqüências a auto-responsabilidade da vítima e a diminuição ou exclusão da responsabilidade do agente delitivo, o que se dá mediante a exclusão da tipicidade ou da antijuridicidade penais. 


\subsection{Natureza. Requisitos de existência, validade e eficácia}

O consentimento do ofendido tem pontos comuns ao consentimento civil, mas sua natureza é eminentemente penal, com ele não se confundindo. $O$ consentimento penal constitui instituto autônomo. fundamentando-se primordialmente na capacidade de autorização. pela pessoa, sobre a ingerência de terceiros em seus bens, de forma a diminuir ou a excluir a responsabilidade penal do agente. A relação fundamental dá-se entre o ofendido e o Estado, e não entre o ofendido e o ofensur. Diverso ocorre no consentimento civil, que se encontra sempre vinculado a uma relação negocial. Ele se fundamenta primordialmente no poder de barganha entre duas ou mais partes sobre a disposição de bens. Seu infoque é a relação entre estas partes, e não aquela entre a pessoa e o Estado. ${ }^{10}$

Outra difurença refere-se a sua finalidade. $\mathrm{O}$ consentimento do ofendido busca a exclusão ou a diminuição da responsabilidade penal do agente delitivo. Já o consentimento civil prima pela composição entre as partes. Diversamente do consentimento civil, o consentimento do ofendido está imerso na teoria do tipo, sendo discutido nas esferas da tipicidade e da antijuridicidade, e apresentando limites próprios ao Direito Penal.

Para que o consentimento exista é necessária a presença do ofendido, do ofensor, da ingerência $\mathrm{cm}$ um bem juridicamente relevante pelo ofensor e da manifestação da aquiescência, pelo ofendido, sobre esta ingurência. $O$ ofendido $c$ a pessoa portadora de bens jurídicos relevantes que manifesta a vontade de ingerência em seus bens por terceiro. Já o ofensor é a pessoa (tcrceiro) que realiza esta ingerência nos bens juridicamente relevantes do ofendido, mediante a manifestação de sua vontade. Note-se que tanto o ofendido quanto o ofensor são pessoas, pois somente elas são passiveis de possuir bens juridicamente relevantes. bem como de praticar ações delitivas, sendo penalmente responsabilizadas e recebendo a respectiva sanção.

$\dot{E}$ inconteste que a pessoa física pode figurar tanto como ofendida quanto ofensora. Em relaçâo à pessoa jurídica. ela pode figurar como ofendida no limite dos bens

10 H.-H. Jescheck afirma que "El consentimiento tampoco constituye ninguna acción juridica, en el sentido del Derecho Civil, que pudiera tratarsc análogamente a la declaración de voluntad, pues en Derecho Penal no importa la protección del menor de edad ni la protección del tráfico juridico, sino únicamente la cuestión del merecimiento de pena de una acción a la que ha dado su consentimiento el lesionado. El consentimiento constituye una figura peculiar del Derecho Pinal, cuyos requisitos de eficacia deben determinarse según que la conformidad con la agresión al objeto de la acción protegido sea o no expresión de la libertad de decisión personal del titular del bien jurídico reconocida por el ordenamiento jurídico, pues sólo esto resulta decisivo para la justificación del hecho." (grifos do original). Id.. ibid.. p. 520-521. 
penais a ela atribuidos, tais como a honra, a propriedade, dentre outros. "A maior parte da doutrina sustenta que ela não pode figurar como ofensora, vez que não é passível de responsabilidade penal, mas há autores que entendem de forma contrária. ${ }^{12}$

A existência do consentimento depende ainda da manifestação de aquiescência pelo ofendido. Aquiescência é a vontade de sofrer a ingerência no bem jurídico, diminuindo ou excluindo a responsabilidade penal do agente. Quanto à forma de manifestação, há três teorias sobre o tema, quais sejam: i) a teoria da declaração da vontade; ii) a teoria da direção da vontade; e iii) a teoria intermediária.

A teoria da declaração da vontade coloca que o consentimento deve manifestar-se externamente como negócio jurídico, oriundo do Direito Civil. Já a teoria da direção da vontade coloca que basta a pura aquiescência interna do ofendido, não sendo necessária a sua exteriorização. Por fỉm, a teoria intermediária coloca que o consentimento deve ser reconhecido de algum modo pelo agente delitivo. ${ }^{13}$

Em adesão à teoria intermediária, tem-se que a manifestação do consentimento deve ser externa e perceptível ao agente delitivo. A exteriorização pode ocorrer de forma expressa ou tácita, especílica ou genérica. Será expressa se perceptível de pronto pelo ofensor, ocorrendo principalmente através das formas verbais de manifestação. Ex.: A diz para B: "Me dê um tapa na face." Será tácita se perceptivel através do comportamento do ofendido. Ex.: A entrega a B, seu inimigo capital, um revólver engatilhado, posicionando-se bem em frente ao cano da arma. Será específica se dirigida a uma ou mais pessoas determinadas. Ex.: Autorização de A para que B e C, especificamente, recebam e leiam suas correspondências. Será genérica se dirigida a uma coletividade. Ex.: Consentimento do proprietário que permite a qualquer pessoa colher as frutas produzidas em seu pomar. ${ }^{14}$

Com a manifestação do consentimento, a relação entre ofendido e ofensor ganha contornos especiais, passando o primciro a ocupar a posição de sujeito ativo ou consenciente, e o segundo, a de sujeito passivo ou consentido. Sujeito ativo ou consenciente é a pessoa portadora de bens relevantes que outorga o consentimento para a sua ingerência pelo ofensor. Já o sujeito passivo ou consentido é a pussoa que recebe o consentimento para realizar a ingerência nos bens juridicos do ofendido, ou consenciente.

Cf. PIERANGeli, J. H. O Consentimento do Ofendido na Teoria do Delito. São Paulo: Revista dos Tribunais, 200I. p. 135.

1. Dentre eles, S. S. SHECAIRA, A Responsabilidade Penal da Pessoa Juridica de Acordo com a Lei $n$. 9.605/98. São Paulo: Revista dos Tribunais, 1998.

13 Cf. JESCHECK. H.-H. Tratado de derecho penal. cit., p. 521.

14 Cf. PIERANGELI, J. H. O Consentimento do Ofendido, cit. p. 129-130. 
O primiro é o emissor do consentimento e receptor da ação delitiva, enquanto que o segundo é o receptor do consentimento e o emissor da ação.

Ressalte-se que a aquiescência sobre a ingerência em determinado bum que não se encontra protegido no âmbito do tipo penal não apresenta qualquer relevância ao Direito Penal. Ex.: Se A consente que B guarde as roupas do primeiro no armário do último, tal conscntimento não será penalmente relevante, ante a inexistência de um tipo que assegure o direito de $\mathrm{A}$ ter suas roupas guardadas em scu próprio armário.

A ingerência do consentido acarreta sempre na lesão de um bem jurídico relevante. Entretanto, o bem lesado nem sempre é o objeto de proteção do tipo penal. No consentimento-atipicidade, que, repita-se, ocorre somente nos tipos penais que protegem a liberdade de disposição de bens pelo indivíduo, o consentimento mantém intacto o bem objeto de tutela penal (liberdade de disposição), provocando a lesão de outros bens juridicamente relevantes, tais como a propriedade, a integridade física, dentre outros.

O delito de lesão corporal leve, presente no art. 129, caput, do CP. é um tipo que permite o consentimento-atipicidade, pois tutela a liberdade de disposição da integridade física pelo indivíduo. Se A pede a B que este último lhc dê três chicotadas. não haverá lesão ao bem tipicamente protegido, qual seja, a liberdade de disposição, por A, de sua integridade física, mas apenas à sua integridade fisica em si. A integridade física é um bem juridicamente e penalmente relevante, mas não é o objeto de proteção do tipo acima descrito.

Já o consentimento-justificação implica sempre a lesão a um bem tipicamente protegido, exceto nos crimes de perigo, em que a lesão pode ou não ocorrer. Veja-se o delito de homicídio, presente no art. 120, caput, do CP O consentimento do consenciente necessariamente gera a lesão ao bem penal vida, mesmo que o consentimento funcione como causa de justificação, excluindo o injusto. Isso porque o consentimento-justificação pressupõe tipos cujo objeto de proteção não é a capacidade de disposição de bens pelo indivíduo, mas os demais bens.

Para que o consentimento seja válido é necessário que o consenciente possua uma capacidade natural de discernimento para entender a renúncia do bem penalmente protegido. ${ }^{15}$ Também é necessário que sua vontade seja produzida e manifestada sem vícios - erro, coação e fraude.

A capacidade para a outorga do consentimento equivale à capacidade para a imputabilidade penal. Isso porque o discernimento necessário para a outorga do

is H.-H. Jescheck coloca a capacidade natural de entendimento e discemimento do consenciente como requisito de eficácia do consentimento. Melhor seria cnquadrá-la como requisito de validade, pois o consentimento outorgado sem esta capacidade não apresenta sequer reconhecimento como tal pelo ordenamento jurídico. Tratado de derecho penal cit., p. 521-522. 
consentimento está estritamente vinculado àquele necessário ao entendimento do caráter criminoso da conduta realizada pelo agente. Somunte podem dispor de bens penalmente relevantes aqueles que conseguem entender o caráter criminoso da ingerência não autorizada sobre os bens juridicos de outrem. ${ }^{10}$

$\mathrm{O}$ art. 26, c.c. o art. 28, ambos do CP, apresentam uma presunção absoluta de que são imputáveis as pessoas com discernimento mental completo e com idade igual ou superior a dezoito anos. Estas pessoas teriam sempre a capacidade para outorgar validamente o consentimento, dada a presunção inconteste de seu discernimento. Entretanto, tal presunção deve ser relativa, não absoluta. Se comprovado que, no caso concreto, o consenciente apresenta plena capacidade de entendimento e de discernimento, então o consentimento por ele outorgado será válido independentemente de sua idade. Se, todavia, comprovado que, embora apresentando dezoito anos completos ou mais, a pessoa não apresenta capacidade suficiente de entendimento e discernimento, então o consentimento por ela outorgado não será válido.

Segundo o art. 26, caput, do CP, as pessoas com doença ou desenvolvimento mental incompleto ou retardado inteiramente incapazes de entender o caráter delitivo da ação são inimputáveis. Não podem. assim. outorgar validamente o consentimento. Contudo, se esta doença ou má-formação mental gerar uma incapacidade relativa para entender o caráter delitivo do fáto, então o consentimento será parcialmente válido, podendo reduzir a pena do consentido de um a dois turços, em analogia ao art. 26, parágrafo único, do CP. O mesmo diga-se em relação à embriaguez provenicnte de caso fortuito ou força maior: se ela causar a incapacidade absoluta de disccrnimento do consenciente, então seu consentimento não será válido. Se, entretanto, ela causar uma incapacidade relativa, então a pena do consentido pode ser reduzida de um a dois terços, tudo em analogia ao art. 28, inciso 11 , do CP.

Portanto. no tocante à capacidade do consenciente. a outorga do consentimento será válida para os imputáveis, inválida para os inimputáveis e parcialmente válida para os sımi-imputáveis. Como conseqüência tem-se que a outorga válida exclui a responsabilidade penal do conscntido, a outorga inválida não a exclui e a outorga parcialmente válida pode reduzir a pena de um a dois terços.

A doutrina divide-se sobre a possibilidade de outorga do consentimento por representação. Tem-se, para nós, que este tipo de outorga não é possivel, pois a renúncia

16 J. H. Pierangeli ressalta que "Adquire, pois, o indivíduo a sua capacidade penal aos 18 anos. Mas não a adquire tão-somente o imputado, mas, também, o consenciente, porquanto seria inadmissivel que em um mesmo Código se estabelecesse duas idades para uma mesma capacidade penal, ou. por outras palavras, uma para a prática do fato e outra para consentir em fato que a justifica." O Consentimento do Ofendido cit. p. 138. 
dos bens penalmente relevantes é um direito personalíssimo de seu portador. Se a capacidade de outorga do consentimento está estritamente vinculada à imputabilidade penal. e se a responsabilidade penal é personalissima, então a capacidade para a outorga do consentimento também deve ser. ${ }^{17}$

Para a validade do consentimento é necessário não apenas que o consenciente seja capaz, mas também que sua vontade seja produzida e manifestada sem vícios. Os principais vícios da vontade são o erro, a coação e a fraude ${ }^{18} \mathrm{O}$ erro ocorre quando o consenciente equivoca-se sobre as circunstâncias ou elementos do fato, conhecendo-o de forma distinta, não correspondente à realidade, declarando uma vontade diferente da que teria caso a conhecesse. Este vício é causado por um processo manifestamente intrapsíquico, nisso diferenciando-se da fraude, provocada por artilicio empregado por outrem. $\mathrm{O}$ erro na outorga do consentimento não se confunde com aqueles descritos nos arts. 20 e 21 do CP, visto que o primeiro (erro na outorga) ocorre em relação ao consenciente, enquanto que os demais (erro de tipo e erro de proibição) ocorrem em relação ao ofensor, que pode ou não ser o consentido. ${ }^{19}$

Para que o erro do consenciente sobre os elementos ou circunstâncias do fato torne nulo o consentimento é necessário que ele ocorra por culpa do consentido. Neste caso, o consentido responderá apenas por crime culposo, vez que não há a intenção de ludibriar o consenciente. ${ }^{20}$ Se o erro originar-se por culpa do consenciente, então o consentimento será válido. Por fim, se o erro ocorrer por culpa de terceiro, então o consentimento continuará sendo válido em relação ao consentido, respondendo este terceiro pelo delito em sua modalidade culposa.

Ex.: A, a partir de sucessivos exames realizados pelo médico $B$, soube que sofria de uma grave doença em um de seus rins. submetendo-se, mediante consentimento, a uma complexa cirurgia para a retirada do órgão, cirurgia esta procedida pelo médico $\mathrm{B}$.

17 J. H. Pierangeli, coloca que o consentimento penal pode ser dado pelo representante civil, estando adstrito aos limites da representação. O Consentimento do Ofendido cit. p. 146-149. Na mesma csteira C. Roxin, quando afirma que a representação penal segue o direito de familia, sendo que o civilmente responsável também o será penalmente. Derecho penal cit.. p. 542-544. Tais posicionamentos não são apropriados. pois transfercm a representação. instituto típico do Direito Civil, ao consentimento do ofendido, instituto de natureza eminentemente penal, desconsiderando as peculiaridades do Direito Penal, principalmente no que se refere ao caráter personalissimu da pena. Na esfera civil, o representante legal tem poderes para outorgar o consentimento em nome do representado, pois também é responsável pela reparação das lesões de natureza civil causadas por este último. $\mathrm{Na}$ esfera penal, entretanto, o representante não apresenta poderes para outorgar o consentimento penal de seu representado, vez que não é responsável pelas lesões aos bens penais provocadas pelo último.

18 Autores como Jescheck e Jakobs utilizam o termo "engano" pra se referirem à fraude.

19 O crro do consentido é tratado como erro de tipo (art. 20 do CP) em relação ao consentimento-atipicidade, e como erro de proibição (art. 21 do CP) em relação ao consentimento-antijuridicidade.

20. A intenção de ludibriar o consunciente configura fraude. outro de vicio da vontade. vez que năo existe a figura do erro doloso. 
Posteriormente, comprova-se que A nunca apresentou qualquer moléstia no rim retirado, e que os exames detectaram a doença porque foram realizados com procedimentos inadequados, não-recomendados pelo corpo médico do hospital.

Neste caso, B deve ser responsabilizado por lesão corporal culposa, pois, embora a cirurgia tivesse sido realizada mediante o consentimento de $A$, este consentimento foi produzido mediante erro, pela conduta culposa de $\mathrm{B}$, motivo pelo qual se tornou nulo. Se, no mesmo exemplo, os exames tivessem sido realizados pelo médico $\mathrm{B}$ e a cirurgia procedida, a partir deles, pelo médico $C$, então $C$ não poderia ser responsabilizado por lesão corporal, vez que a cirurgia foi realizada mediante o consentimento de $\mathrm{A}$, e o erro em seu consentimento não foi causado por culpa de $\mathrm{C}$, mas de B. Neste caso, o consentimento de A seria válido, e B seria responsabilizado por lesão corporal culposa. Se, entretanto, comprovado que os resultados dos exames foram errôneos porque $A$, ao submeter-se a eles, ingeriu uma substância que sabia não poder ingerir, pois fatalmente causaria alteração no diagnóstico, então seu consentimento seria válido, e ninguém seria responsável pela lesão.

No exemplo a cima, a responsabilidade penal de A, B, e C está em consonância com a teoria da imputação objetiva, pois considera o aumento do risco que cada um proporcionou para a ocorrência do resultado lesivo, qual seja, a retirada do rim do paciente $\mathrm{A}$, resultado este previsto no tipo de lesão corporal de natureza gravíssima (art. 129, $\S 2^{\circ}$ inciso III).

Para retirar a validade do consentimento, o erro pode recair sobre qualquer elemento ou circunstância do fato, desde que este elemento ou circunstância seja determinante para sua outorga. ${ }^{21}$ Ex.: A não pode invocar a nulidade de seu consentimento porque errou sobre a extensão do procedimento cirúrgico ao qual foi submetido, e que the determinou uma lesão corporal de maior monta. A pensou que a incisão seria de $10 \mathrm{~cm}$, quando na verdade foi de $25 \mathrm{~cm}$, observadas, contudo, as devidas normas técnicas. A análise da relevância do erro deve ser verificada caso a caso pelo magistrado.

A fraude ocorre quando o consentido ou terceiro emprega, dolosamente, artificio ou ardil com vistas a deturpar o conhecimento do consenciente sobre os elementos ou as circunstâncias do fato, fazendo com que ele outorgue um consentimento que não existiria caso o consenciente conhecesse a realidade. Ao contrário do erro, na fraude a deturpação no conhecimento do sujeito ativo ocorre por estímulos eminentemente externos, não intrapsíquicos.

21 H.-H. Jescheck assevera que apenas o erro sobre a qualidade ou sobre a quantidade da lesão ao objeto da ação causa a ineficácia do consentimento. O mesmo diga-se em relação à fraude. Tratado de derecho penal cit., p. 522. 
Como o erro, a fraude também pode ser causada pelo consentido ou por terceiro. A diferença reside em que, ncla, o fraudador não atua culposamente, mas dolusamente. com vistas a ludibriar o consenciente para obter a manifustação de sua aquiescência. Disso decorre que a fraude promovida pelo consentido torna nulo o consentimento, respondendo ele por crime doloso. Se, entretanto, a fraude é promovida por terceiro, então o consentimento é válido em relação ao consentido. respondendo o tercciro por crime doloso. A fraude também pode recair sobre qualquer elemento ou circunstância fática, desde que relevante para a outorga do consentimento, devendo esta relevância ser analisada caso a caso pelo magistrado.

Por fim, tem-se a coação, que é o consentimento outorgado mediante violência física ou moral, exercida pelo consentido ou por terceiro. Não se trata, tal como no erro, de um conhecimento equivocado, nem tampouco, como na fraude, de um conhecimento deturpado. Na coação, o consenciente tem pleno conhecimento dos elementos e das circunstâncias fáticas que envolvem scu consentimento. A diferença é que a vontade por ele manifestada contraria frontalmente sua vontade interna, devido a uma contra-ação pelo coator.

No consentimento, a coação produz os mesmos efeitos da fraude. Se realizada pelo consentido, o consentimento será nulo, sendo o agente responsabilizado por crime doloso. Se realizada por terceiro, o consentimento será válido ao consentido, respondendo o terceiro por crime doloso. Como os outros vicios de vontade, a coação pode recair sobre qualquer elemento ou circunstância fática, desde que este elemento ou circunstância seja relevante para a outorga do consentimento.

Ao contrário do consentimento-justificação, o consentimento-atipicidade admite a existência de determinados vícios da vontade sem que isso gere a nulidade de sua outorga. Tudo depende da análise do correspondente tipo penal. Por exemplo: no delito de violação de domicílio (art. 150 do CP) qualquer vício da vontade por parte do consenciente gera a nulidade do consentimento, pois o tipo prevê "Entrar ou permanecer, clandestina ou astuciosamente, ou contra a vontade de quem de direito, em casa alhcia ou em suas dependências" Já no tipo de estupro (art. 213 do C.P) apenas a coação gera a nulidade do consentimento, pois o tipo prevê "Constranger mulher à conjunção carnal, mediante violéncia ou grave ameaça" O mesmo ocorre nos outros tipos que apresentam a violência ou a gravc ameaça como seu elemento estrutural.

Para que o consentimento seja eficaz é necessário que ele tenha por objeto a lesão a um bem jurídico passivel de disposição pela pessoa. Quanto à sua capacidade de disposição, os hens juridicos podem ser classificados em: i) bens totalmente renunciáveis: 
e ii) bens parcialmente renunciáveis. Os primeiros são sempre passíveis de disposição pela pessoa. Já os segundos são passiveis de disposição somente em alguns casos.

Esta capacidade de disposição é determinada pelo consenso social, dependendo primeiramente da importância social do bem tutelado e da gravidade da lesão, e secundariamente das demais circunstâncias que envolvem o fato, tais como o estado em que se encontra o bem, a finalidade da disposição, dentre outros.

Quanto à relevância social, os bens podem ser classificados em: i) bens individuais; b) bens sociais; c c) bens híbridos, ou scja, que ora são individuais e ora sociais, tudo de acordo com a gravidade da lesão. ${ }^{22}$ Os bens individuais, como a honra, são totalmente renunciáveis. Já bens sociais, como a vida, são parcialmente renunciáveis, dependendo sua renúncia das demais circunstâncias que envolvem o fato. Por fim os bens híbridos, como a integridade física, são individuais quando a lesão for de pequena monta e sociais quando a lesão for de grandes proporções, neste último caso também dependendo sua renúncia das demais circunstàncias que envolvem o fato.

Nenhum bem jurídico é totalmente irrenunciável, pois sempre depende da gravidade da lesão e das demais circunstâncias fáticas. Até mesmo a vida, bem jurídico de maior relevância ao Direito Penal. é passivel de disposição em alguns casos raros. tais como o suicídio e a eutanásia, por entender a sociedade que, neles, a manutenção da vida é mais danosa do que o seu término. Entender de forma diversa, rotulando determinados bens como indisponiveis ou irrenunciáveis, significa extinguir de início a discussão sobre a sua disponibilidade. Isso cria injustiças manifestas, principalmente considerando que os valores sociais estão em constante mudança, exigindo certa flexibilidade do Direito Penal.

O consentimento é eficaz quando outorgado sobre um bem totalmente renunciável, ou se, outorgado sobre um bem penal parcialmente renunciável, as circunstâncias do fato autorizem sua renúncia pelo consenciente. Caso contrário, ele não conseguirá excluir o incremento do risco causado pela ação delitiva do ofensor, apresentando existência e validade. mas não sendo capaz de gerar efeitos na eslera penal.

\subsection{Consentimento presumido}

Questão muito discutida é a eficácia do consentimento presumido. Consentimento presumido é aquele que se pressupõe diante das circunstâncias, ${ }^{23}$ ocorrendo nas situações em que o consentimento poderia ser emitido validamente, mas

\footnotetext{
22 Os bens individuais também apresentam rùlevância social e vice-versa, pois nāo é possível pensar em uma sem a outra. Esta classificaçāo foi adotada considerando-se a relevância (individual ou social) preponderante, com a finalidade de facilitar a compreensão.

23 Cf. J. H. PIERANGELI. O Consentimento do Ofendido, cit. p. 161.
} 
não $u$ é. pois o ofendido ${ }^{24}$ está impossibilitado de outorgá-lo. ${ }^{25}$ Neste caso, o agente realiza uma abstração, agindo como se o consentimento fosse por ele manifestado.

O consentimento presumido exige os mesmos requisitos do consentimento próprio e depende de três fatores: ${ }^{26}$

i) Ponderução de interesses do ofendido pelo ofensor. O consentimento presumido requer que dois ou mais interesses do ofendido encontrem-se em risco. cabendo ao ofensor escolher aquelc mais vantajoso ao primeiro. Note-se que ambos os interesses ponderados pelo ofensor pcrtencem ao ofendido, motivo pelo qual está incorreta a afirmação de que o consentimento presumido é uma espécie de estado de neccssidade justificante. pois neste último os interesses ponderados pertencem um(ns) ao ofendido e outro(s) ao ofensor;

ii) Decisão que o ofendido teria tomado se soubesse das circunstâncias. O ofensor deve agir conforme a vontade que o ofendido teria nas circunstâncias em que se encontra. Em todos os casos de consentimento presumido deve-se preservar a vontade do ofendido, mesmo yue ela seja irracional ou ilógica, pois este consentimento deve refletir a sua liberdade de disposição de bens;

iii) Risco permitido. O ofensor deve, sempre que possível, agir no âmbito do risco permitido. Há, contudo, casos em que o agente incrementa o risco do ofendido e mismo assim sua conduta não gera efeitos penais, quando comprovado que o ofendido consentiria sobre o risco provocado pelo agente. Ex. A sofreu um acidente de automóvel e encontra-se inconsciente em um hospital. $\mathrm{B}$, médico de plantão que socorre $\mathrm{A}$, sabe que se A não sofrer imediatamente uma cirurgia de alto risco ( $80 \%$ de risco de morte) certamente ficará tetraplégico. Se for submetido à cirurgia e resistir a ela, A não terá qualquer defíciência. Se comprovado que A. nas circunstâncias, optaria pela cirurgia, então B não poderá ser responsabilizado pela eventual morte de $\mathrm{A}$, embora tenha incrementado o risco de morte do paciente em nivel acima do permitido. ${ }^{27}$

Por ser inferido pelo ofensor através de um juizo de abstração, nem sempre correspondendo à real vontade do ofendido, o consentimento presumido deve ter limites

24 Utilizam-se aqui os termos ofendido e ofensor em substituição aos termos consenciente e consentido (item 2.2) pois no consentimento presumido não há manifestação do consentimento.

25 Cf. H.-H. Jescheck, o consentimento presumido "Tiene lugar cuando el consentimiento, que scgún la situación hubiera podido ser emitido vảlidamente, no concurre, ni tampoco puede ser recabado a tiempo. porquc إl lesionado o su representante legal no resultan localizables o no se hallan conscientes, pese a que una valoración objetiva de todas las circunstancias efectuada i $x$ ame muestra que la prestación del consentimiento hubiera sido esperable con seguridad (RG 61, 242 [256]; BGH 16, 309 [312])" Tratado de derecho penal cit., p. 524-525.

26 Id., ibid., p. 525-526.

27 Para Jescheck, o consentimento presumido requer que a conduta do agente esteja scmpre no âmbito do risco permitido. Ibid.. p. 526. 
bem restritos, ocorrendo somente para a proteção da vida ou da integridade física da pessoa, principalmente no tocante às intervenções cirúrgicas. Isso porque, na maioria dos casos que n envolvem, a ação lesiva é praticada com a finalidade de diminuir o risco do ofendido. Assim, a questão é resolvida pela teoria da imputação objetiva, com a conseqüente atipicidade da ação, o que torna irrelevante a análise do consentimento presumido.

Exemplificando: A sofre um acidente automobilístico e encontra-se inconsciente, sendo socorrido peio médico B. B submete A a uma cirurgia de baixo risco, mas que se não realizada provocará a morte do paciente. Intretanto, embora realizada de acordo com os procedimentos médicos recomendados, a cirurgia acarreta a morte de $\mathrm{A}$. Neste caso, a conduta de B não será sequer típica, e isso devido à teoria da imputação objetiva, vez que o agente diminuiu (e não incrementou) o risco do paciente. Assim, não é necessário que se discuta sobre a existência ou-não de consentimento presumido, pois a mera análise do incremento do risco já resolve a questão.

Portanto, a eficácia do consentimento presumido está restrita aos casos de proteção da vida ou da integridade física da pessoa, mormente quando das intervenções cirúrgicas, apresentando relevância somente quando a ação do ofensor incrementar o risco do ofendido.

\subsection{Consentimento ex post}

Outra questão pertinente refere-se à eficácia do consentimento outorgado durante ou após a execução do evento, este último também chamado de consentimento ex post. Tanto no primeiro quanto no segundo caso o consentimento será eficaz, pois o consentido não incrementou o risco do consenciente. É o próprio consenciente quem se autocoloca em risco. Como pela teoria da imputação objetiva a análise do incremento do risco antecede a análise da própria tipicidade, e conseqüentemente. do dolo que está a ela atrelado, então não há o que se falar em intenção do agente. pois a conduta não será sequer típica. Mesmo que se considere que inicialmente, ou seja, até a outorga do consentimento, houve um incremento do risco por parte do consentido, tal incremento foi absorvido pela autocolocação em perigo do consenciente.

Grande parte da doutrina defende que o consentimento outorgado após a realização do evento não apresenta eficácia penal, vez que assume natureza de perdão. ${ }^{28}$

28 Neste sentido. J. H. PIERANGEli, O Consentimento do Ofendido cit., p. 157, quando infere que o consentimento ex post. quando outorgado nos crimes de ação penal privada, é uma forma de "perdão tácito" Ressalva, todavia, que neste caso trata-se de Direito Processual Penal, e não em consentimento do ofendido. matéria de Direito Penal. 
Esta assertiva é imprópria. O CP brasilciro prevê duas formas de perdão: o perdão do ofendido, previsto em seu art. 107, inciso V, c o perdão judicial, previsto em seu art. 107, inciso IX. O primeiro ocorre no curso da ação penal privada, quando o querelante perdoa o querelado, extinguindo a punibilidade do delito. Já o segundo ocorre nos casos expressamente previstos em lei, sendo decretado pelo magistrado. Ambos causam a extinção da punibilidade. ${ }^{29}$

O consentimento ex post não apresenta natureza de perdão do ofendido, pois, diferentemente do segundo, não está restrito aos crimes de ação penal privada, estendendo-se a uma gama muito maior de crimes. Disso decorre que o consentimento não necessita ser dado durante a ação penal privada para que tenha eficácia, podendo ser outorgado antes mesmo da ação, e antes ou no decurso das ações penais públicas. Além disso, diversamente do perdão do ofendido, que é causa de extinção da punibilidade, o consentimento pode ser tanto causa de exclusão do tipo quanto da antijuridicidade da conduta.

Uma outra diferença que se pode apontar é que o consentimento não requer a aceitação do ofensor para que seja eficaz. O perdão judicial. ao contrário. só trará benefícios ao ofensor se ele o aceitar. Por fim, os institutos de Direito Processual Penal. como o direito de queixa, não podem ser confundidos com aqueles inerentes ao Direito Penal, como o é o consentimento.

O consentimento ex post também não apresenta natureza de perdão judicial. pois este último é concedido pelo magistrado indıpendentemente da vontade do ofendido ou do ofensor. Ele só pode ser concedido nos casos expressamente previstos em lei, tais como no art. $121, \S 5^{\circ} 129, \S 8^{\circ}$ e $180, \S 5^{\circ}$ todos do CP, bem como no art. 186. parágrafo único. do Decreto-lei n. 7.661/45 (Lei de Falências). Outra diferença é que o perdão judicial é sempre causa de exclusão da punibilidade. enquanto que $\circ$ consentimento pode excluir ora o tipo, ora a antijuridicidade penal. O perdão judicial não diz respeito à aquiescência do ofendido quanto à ingerência do ofensor em seus bens juridicos, mas à política-criminai do Estado, que cm determinados casos escolhe extinguir a punibilidade do agente.

Portanto, o consuntimento será eficaz antes, durante ou após a realização do evento. ${ }^{30}$ Ressalte-se que o consentimento após o evento será eficaz somente até o trânsito

29 Cf. PRADO. L. R. Curso de Direiro Penal Brusileiro. Sāo Paulo: Ruvista dos Tribunais, 2002. p.634-637.

30 J. H. Pierangeli, difendendo a teoria da renúncia da tutela jurídica, coloca que "O consentimento é válido e aptu à prudução de seu efcito justificante todas as vezes que preceder a realizaçào do evento." $O$ Consentimento do Ofendido cit., p. 157. Para ele. o consentimento será eficaz somente se outorgado antes da consumação do delito ou durante a sua execução, pois apenas nestes casos o ofendido poderá renunciar ao bem juridico. O consentimento posterior não será cficaz, pois a ratificaçào não produz yualquer efeito em relação ao consentimento. Sustenta ainda que se o crime for de ação penal privada, o ofendido pode deixar 
em julgado da sentença penal condenatória, podendo ocasionar a absolvição do réu ou a diminuição de sua pena pelo juiz.

\subsection{Revogação}

O último ponto diz respeito à eficácia da revogação do consentimento pelo consenciente. O consentimento é livremente revogável antes do início da execução do ¿vento, sendo sempre eficaz. nestes casos. Se ocorrer durante a execução, a revogação pode ou-não ser eficaz, tudo dependendo da possibilidade de interrupção do curso causal. Se a conduta puder ser interrompida, então a revogação será eficaz, não se responsabilizando o agente pelos efeitos obtidos antes de sua revogação.

Se, entretanto. a conduta não puder ser interrompida, então a revogação será ineficaz, pois o agente não pode interromper o curso causal. O excesso será sempre punivel. O mesmo diga-se em relação aos casos nos quais o agente, podendo interromper o curso causal através de uma contra-ação, não a réaliza, dcixando que o resultado se verifique.

\subsection{Conseqüências penais do consentimento}

2.6. I. O paradigma dualista

O paradigma dualista é marcado pela idéia de que o consentimento pode excluir tanto o tipo quanto a antijuridicidade penais. A maior parte desta doutrina segue o modelo de Geerds, distinguindo o consentimento do acordo penal.

No Direito Penal contemporâneo foi Geerds ${ }^{31}$ quem primeiro distinguiu o consentimento do acordo. Ambos são marcados pela aquiescência do portador de bens jurídicos. sendo que o acordo tem lugar toda vez que o dissenso for elemento integrante do tipo penal, e o consentimento toda vez que o dissenso não for seu elemento integrante. Disso decorre que, no acordo, a aquiescência exclui o próprio tipo, não havendo lesão ao bem juridico, enquanto que no consentimento a aquiescência não exclui a ação típica, ocorrendo a lesão ao bem.

Veja-se o delito de furto, previsto no art. 155 do Código Penal brasileiro: se A é proprietário de um bem móvel e consentc que B tomc a posse deste bem. não há furto,

de oferecer qucixa-crime como uma forma de perdão tácito. Tais argumentos podem ser válidos para a teoria finalista da açào. que considera primordialmente o dolo do igente. mas nảo para a teoria da imputação objetiva, que considera preliminarmente o incremento do risco.

31 Cf. ANDRADE, M. C. Consentimento e Acordo em Dircito Penal - Contributo para a Fundamentação de um Paradigma Dualisı Coimbra: Coimbra, 1991. p. 137-147. 
mas um mero empréstimo ou uma doação. O mesmo ocorre na violação de domicílio, na modalidade "entrar ou permanecer contra vontade expressa ou tácita de quem de direito" prevista no art. 150 do CP: sc A entra e permanece na casa de B, a seu convite, pratica uma ação irrelevante ao Direito Penal. Tal se verifica ainda nos delitos de constrangimento ilegal (art. 146 do (P), de seqüestro e cárcere privado (art. 148), de roubo (art. 157 do C.P) e em vários outros. Em todos estes exemplos a ação é atípica e até mesmo comum nas relações humanas. Trata-se de exemplos de acordo.

Diverso ocorre no delito de homicídio, previsto no art. 121 do CP Nele, a aquiescência do titular do bem jurídico-penalmente protegido (a vida) não exclui a ação típica, pois há lesão ao bem. O mesmo diga-se em relação ao delito de explosão. presente no art. 251 do CP: eventual aquiescência por parte do (s) ofendido (s) não retira a tipicidade da ação, uma vez que o bem (incolumidade pública) foi lesado. Assim também ocorre na lesão corporal (art. 129 do (P), no perigo de contágio de moléstia grave (art. 131 do $(\mathrm{P})$, e em inúmeros outros. Nestes tipos a aquiescência dá-se através do consentimento, não retirando o caráter típico da conduta do agente.

No acordo, a aquiescência do titular do bem juridico é discutida na esfera da tipicidade, enquanto que no consentimento a aquiescència é discutida na esfera da antijuridicidade, pois a conduta scrá sempre típica. ${ }^{32}$

Para Geerds, a distinção entre acordo e consentimento vai mais além: enquanto o acordo constitui um mero evento, um fato, o consentimento é tido como um instituto de natureza normativa, com características jurídicas. Daí a conclusão de que, ao contrário do consentimento, o acordo não apresenta requisitos de validade e eficácia. gerando efeitos mesmo quando outorgado com os vícios da vontade, tais como o erro, o dolo e a coação, bastando que ocorra nos tipos que o permitem.

Fsta concepção fática do acordo e normativa do consentimento mostra-se equivocada. Ambos, consentimento e acordo, apresentam fundamento jurídico, o que pressupõe uma base fática - sua presença no mundo real-, e uma base normativa - sua previsão na norma penal.

Outro autor relevante na manifestação do paradigma dualista foi Noll, ${ }^{33}$ segundo o qual o consentimento ocorre sempre que se verifique uma lesão ao bem jurídico justificada pela colisão de valores, enquanto que o acordo ocorre quando há uma queda do bem jurídico sem a colisão de valores, afastando-se o próprio bem jurídico protegido. Tanto o consentimento quanto o acordo são denominados por Noll de consentimento.

32 Neste sentido. JESCHECK, WELZEL e ZAFFARONI. Cf. J. H. PIERANGELI, O Consentimento do Ofendido cit., p. 95.

33 Id., ibid., p. 147-151. 
Para Noll, o consentimento excludente da antijuridicidade pressupõ sempre uma colisão entre a liberdade individual e os demais bens jurídicos penalmente tutelados, o que em última instância significa a colisão entre valores e interesses individuais e sociais. Nestes casos, como o tipo penal protege bens que não a liberdade individual, o consentimento não afasta a tipicidade da conduta, mas é capaz de justificá-la se o interesse individual prevalecer sobre o social.

A eficácia do consentimento como fator de justificação depende sempre de uma ponderação prévia de bens, deveres ou, em geral, valores, ${ }^{34}$ pressupondo a relação entre a valoração subjetiva do consenciente e a valoração objetiva da lei, através de sua ordem jurídica e da jurisprudência. Já o consentimento excludente da tipicidade pressupõe a proteção da liberdade individual pelo tipo penal. Neste caso, o consentimento válido afasta a lesão ao bem, afastando por conseqüência a tipicidade da ação.

O maior contributo de Noll foi erigir tanto o consentimento quanto o acordo em bases fáticas e jurídicas, nisso inovando a teoria de Geerds. O acordo deixou de ter aquela estrutura fática rígida para moldar-se aos diversos tipos penais. Entretanto, Noll se equivocou ao tentar conciliar o consentimento como expressão da autonomia individual com o sistema normativo das causas de justificação. Isso porque, enquanto que o primeiro implica um distanciamento da norma, resolvendo-se pela ponderação e prevalência de bens, o segundo implica sua aproximação, pois, tal como as demais causas de justificação, deve estar expressamente previsto na norma penal. Diante desta contradição, Noll preferiu enfatizar o caráter normativo das causas de justificação, em muito limitando, ou até mesmo suprimindo, a autonomia individual. ${ }^{35}$

As idéias de Noll assemelham-se muito àquelas propostas por Casas Barquero. ${ }^{36}$ Segundo ele, o consentimento pode ser dividido em dois tipos, quais sejam: i) o consentimento que exclui o tipo, transformando a conduta em um processo irrelevante. normal, ou socialmente positivo; e ii) o consentimento que exclui o injusto, que não é hábil a retirar a lesividade da conduta. O consentimento que exclui o tipo pressupõe duas categorias de tipos penais: i) tipos que protegem, junto à existência do bem jurídico, a liberdade de disposição pelo indivíduo; e ii) tipos em que própria liberdade de disposição

is Costa Andrade defende que, quando da aplicação das causas de justificação, a ponderação de interesses ć mais correta do que a ponderação de bens, vez que os primeiros são mais abrangentes e llexíveis que os segundos. Os interesses englobam não apenas os bens em colisão, mas também a imporlância que eles apresentam aos respectivos sujeitos portadores. Na ponderação de bens consideram-se apenas os bens segundo o seu valor abstrato. descito no tipo. Já na ponderação de interesses considera-se a situação concreta do caso, analisando-se todos os momentos que possam influenciar na dignidade da tutela. Isso gera maior Justiça quando da aplicação das causas de justificação. Ibid., p. 251-254.

35 Cf. ANDRADE, M. C. Consentimeno e Acordo cit., p. 151-160.

36 La importancia del consentimiento en la teoria general del delito. Doctrina Penal - teoria e práctica en las ciencias penales, Buenos Aires, v. 11, n. 42, p. 213-230, abr./jun. 1998. 
do individuo constitui o bem iurídico, ou seja, a liberdade da pessoa sem mais. Por protegerem a liberdade de disposição do individuo, estes tipos exigem sempre um dissenso entre a vítima e o ofunsor, motivo pelo qual, nestes casos, o consentimento não provoca qualquer tipo de lesão ao bem jurídico. Ao contrário, cle reflete a realização dos valores que o Direito Penal quer tutclar.

Já o consentimento que exclui o injusto pressupõ tipos que tutelam valores importantes à sociedade, incriminando condutas socialmente indesejáveis e reprováveis. Nestes casos, o consentimento não é hábil a afastar a lesividade da conduta, que permanece típica. envolvendo, pois, um conflito entre a liberdade de autodeterminação da pessoa e a integridade dos demais bens. Tal conflito deverá ser resolvido na esfera da antijuridicidade. através da ponderação de bens ou valores. Daí que a importância do consentimento como excludente de antijuridicidade depende sempre do valor que o ordenamento jurídico atribui ao individuo e à sociedade. ${ }^{37}$

Esta tensão ou conflito entrc a autonomia individual e os bens sociais, com a conseqüente resolução na esfera da antijuridicidade, atravís da ponderação de bens e valores, em muito se assemelha ao pensamento de Noll, motivo pelo qual Casas Barquero se deparou com a mesma contradição verificada na teoria do primeiro, ocorrida entre a naturcza normativa das causas de justificação e a axiologia que envolve a ponderação de bens e valores. E, tal como o primeiro, Casas Barquero enfatizou a natureza normativa. razăo pela yual sua teoria merece os mesmos comentários tecidos a Noll.

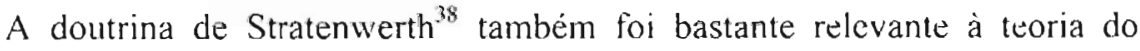
consentimento, pois privilegiou a autonomia pessoal ${ }^{39}$ como fator comum às causas de justificação. Em sua teoria, o autor sustenta que o atentado à autonomia pessoal constitui o próprio fundamento do ilícito penal. Afirma ainda que há duas classes de tipos penais, quais sejam: i) tipos que tutelam tão somente a autonomia individual; e ii) tipos nos quais a autonomia pessoal é apenas um dos objetos de tutela. Nos primeiros o conscntimento exclui a tipicidade, afastando o bem juridicamente protegido, enquanto que nos segundos

37 "Es preciso, por tanto. tener presente en el ámbito del régimen del consentimiento la frecuente y necesaria invocación de valores fundamentales reconocidos constitucionalmente en el marco proprio de un estado social y democrático de derecho. Implica. en definitiva. hacer referencia a la antinomia entre libenad dispositiva personal o de autodeterminacion y el esquema social prefijado por el legislador. Se ha de tratar. en todo caso, de armonizar en el ámbito penal las exigencias de conformar un individualismo que, sin lleg̣ar a ser extremo. pueda complementarse con aquellas otras derivadas del principio de solidaridad social." H. CASAS BARQUERO, ibid., p. 218-219.

38 Cf. ANDRADE, M. C. Consentimeno e acordo cit. p. $161-175$

39 "Na verdade (argumenta o autor), é o imperativo de respeito ao outro, como portador de direitos iguais. que constitui a norma fundamental da convivência humana. Um imperativo que reclama igualınente o reconhecimento do outro como ser autònomo, responsável no âmbito da sua esfera de acção. E que dimana a proibição da ingerência na esfera de interesses alhcios." Id.. ibid.. p. 162. 
exclui a antijuridicidade, permanecendo a lesão aos bens que não a autonomia pessoal. Neste caso, o conflito dá-se entre os interesses individuais e os interesses sociais.

A doutrina de Stratenwerth apresenta algumas incongruências internas, principalmente no que se refere ao conceito de lesão ao bem juridicamente protegido, mas foi relevante para a eleição da autonomia pessoal como fator comum a todas as causas de justificação, incluindo-se aí o consentimento do ofendido, com a conseqüente desvalorização do argumento de que ele seria um elemento estranho ao sistema das causas de justificação.

Costa Andrade, também defensor da teoria dualista, coloca que o paradigma originário de Geerds apresenta contrariedade latente, vez que contrapõe a natureza normativa do consentimento ao conteúdo meramente naturalístico do acordo. Como o consentimento, o acordo também tutela a liberdade individual e apresenta aspectos normativos, não devendo se reproduzir idêntico nos tipos que o prevêem, mas de forma plástica, variável. Isso sugere a necessidade de uma revisão do rígido sistema bipartido de Geerds. $^{40}$

Sustenta que esta revisão não pode ser tão profunda a ponto de suplantar. como querem os monistas, o dualismo consentimento-acordo, pois, apesar de, como o consentimento, o acordo assegurar a autonomia pessoal, ele o faz de forma distinta: não através da colisão entre interesses individuais e sociais, como ocorre no consentimento a nas demais causas de justificação, mas através da incorporação da autonomia individual como objeto mesmo da norma penal." Isso porque o consentimento, por ser uma causa de justificação, pressupõe sempre um conflito entre o interesse social, proveniente do bem juridico tutelado, e o interesse individual, proveniente da autonomia do indivíduo, direito constitucionalmente assegurado. Já o acordo pressupõe a autonomia individual como o próprio objeto de tutela do tipo penal.

4" "A neciessária superação do paradigma originário de Geerds não tem de se fazer pela via da parificação e homogeneização daquelas manifestações, todas reconduzidas à categoria da causa de exclusão da tipicidade. Tudo. pelo contrário, parece reforçar a plausibilidade dogmática da distinçâo e contraposição, em termos renovados, de um consentimento justilicantc e de um acordo que afasta a lipicidade." (grifos do texto). Id., ibid., p. 516.

") "Em vez do 'monopólio naturalístico', reproduzindo-se idêntico em cada tipo, o acordo surge como realidade normativamente confonnada, marcada pela plasticıdade. contingêncra $\mathrm{c}$ variabilidade. $U$ acordo mediatiza, se livre e esclarecido, aquela "comunicação ideal' que se identifica com o bem juridico prolegiclo: uma expressão da liberdade pessoal que só na intersuhjectividade encontra a forma autêntica de arualização. $\mathrm{O}$ acordo assegura a continuidade entre a autonomia pessoal e o bem juridico protegido e. reflexamente. a congruência entre a mesma autonomia c o programa sistémico-social de tutela penal. O que exclui, por definição, os coeficientes de conflitualidade proprios do consentimento. E retira todo o fundamento e pertinéncia a conceitos - como ofendido. réníncia. lesão, etc. - mucleares no discurso do consentimcnto." (grifos do texto) Id.. ibid., p. 517. 
Portanto, de forma geral, o paradigma dualista é marcado por um consentimento bipartido, sendo o primeiro capaz de excluir a tipicidade e o segundo a antijuridicidade da conduta. Ambos os tipos de consentimento fundamentam-se na liberdade ou autonomia individual, que se encontra constitucionalmente assegurada. $\mathrm{O}$ consentimento excludente do tipo não pressupõe a lesão ao bem jurídico, mas, ao contrário, sua realização, fazendo com que a conduta seja normal e até mesmo esperada nas relações humanas. Já o consentimento excludente da antijuridicidade requer a lesão ao bem juridicamente protegido, de relevância social, causando um conflito entre o interesse pessoal, com fundamento na autonomia do indivíduo, e o interesse social, com fundamento no valor público do bem tutelado, conflito este a ser resolvido na esfera da antijuridicidade.

A evolução do paradigma de Geerds resultou na necessidade de um modelo mais variável e flexível de acordo, assente não apenas em suportes fáticos, mas também jurídicos, vez que em última instância o acordo também é determinado pelo tipo penal, e valorativos, na medida em que o legislador escolhe quando e em que medida tutelar a autonomia do indivíduo. Nisso diferencia-se do consentimento, no qual a discussão valorativa ocorre quando da aplicação normativa, e não de sua elaboração.

\subsubsection{O paradigma monista}

O paradigma monista defende que o consentimento somente pode assumir a função de causa de exclusão da tipicidade. Sua origem encontra-se na teoria liberal, como expressão máxima da liberdade do indivíduo, de forma que nas relações entre o privado e o público, o individual e o social, o primciro sempre há de prevalecer sobre o segundo.

Costa Andrade ${ }^{42}$ afirma que a teoria monista apresenta dois fundamentos, quais sejam: a árca de tutela e o conceito de lesão. O primeiro defende que o consentimento coloca o bem jurídico fora da área de tutela penal, causando a renúncia à proteção estatal. Já o segundo apresenta duas correntes, quais sejam: i) a de que a competência para a disposição é um elemento constitutivo do próprio bem jurídico, sendo que o consentimento exclui a lesão do bem jurídico como tal; e ii) a de que a violação do bem jurídico é a violação da exigência de respeito proveniente de uma instituição, sendo o consentimento a expressão de uma lesão aparente ao bem penal.

Schmidhäuser ${ }^{43}$ foi adepto desta segunda corrente. Para ele, bem juridico é "a exigûncia de respeito (emergente dos bens individuais ou comunitários) a cuja violação

\footnotetext{
12 Id., ibid., p. 178-183.

43 Id., ibid., p. 185-188.
} 
não permitida os órgãos estaduais estão legitimados a reagir com conseqüências juridicas (jurídico-penais, de Direito Civil ou de Direito Público, em geral)" 44 Assim, a lesão ao bem jurídico é a lesão a esta exigência de respeito. Já a lesão aparente ao bcm jurídico ocorre quando a ação parece violar a exigência de respeito, mas não o fà̀.

Neste contexto, o consentimento é causa de lesão aparente ao bem jurídico. pois quando a pessoa consente, ela abandona os bens juridicos consentidos, fazendo com que caia a exigência de respeito. Schmidhäuser, mesmo filiado à teoria monista, diferencia o consentimento do acordo. Fnquanto no consentimento há uma lesão aparente ao bem jurídico, o que implica um desvalor aparente do resultado, no acordo não há qualquer tipo de lesão. Em outras palavras, não se cogita nenhuma lesão ao bem, não há sequer desvalor aparente do resultado. Na prática, ambos causam a exclusão da tipicidade, ante a inexistência de lesão ao bem jurídico.

Molina Arrubla ${ }^{45}$ não defende a área de tutela ou o conceito de lesão como fundamento do consentimento excludente da tipicidade. Diversamente dos demais autores monistas, ele coloca que o Direito Penal, por sua própria natureza, protege apenas bens de interesse público, pois sua ofensa abala toda a sociedade. Daí não ser possível que o particular derrogue ou renuncie a proteção penal de determinados bens.

Excluída a autonomia pessoal do consenciente, o máximo que o consentimento pode fazer é excluir a incidência dos tipos penais que se fundamentam no dissenso entre consenciente e consentido. Daí que a eficácia do consentimento dependerá única e exclusivamente da vontade do legislador, na medida em que tixar os tipos que admitem o acordo.

A doutrina de Molina Arrubla apresenta-se bastante contraditória, vez que, filiada à corrente monista, conhecida pela relevância que atribui à autonomia individual, ela se faz extremamente retrógrada no que tange à natureza dos bens protegidos pelo Direito Penal, bem como à capacidade de disposição de bens pelo indivíduo. Se, por um lado, a prevalência da liberdade individual sobre todos os outros interesses penalmente tutclados é equívoca. por outro, a mutilação desta liberdade, restrita aos casos de acordo e estritamente vinculada à atividade legislativa, é igualmente nociva. pois destoa não apenas das necessidades político-criminais, mas também da lógica dogmática.

Não é sensato que a vontade do ofendido tenha tamanha relevância nos casos de acordo e, ao mesmo tempo, scja completamente irrelevante nos casos de consentimento. Além disso, a tese ignora as hipóteses em que o legislador erige o

\footnotetext{
t4 SCHMIDHÄUSER (Eb.), Strafrechı. Allgemeiner Tíl. Tübingen, 1475, p. 37, apud ANDRADE. M. C. Consentimento e Acordo cit., p. 185.

ts Ihid., p. I|-38.
} 
consentimento como forma legal ou supralegal de justificação. A tese de Molina Arrubla apresenta-se inadequada não apenas ao sistema monista, mas também aos fundamentos do próprio Direito Penal.

Os adeptos da teoria monista defendem. além dos argumentos relativos à tipicidade, a idéia de que o consentimento não se coaduna ao sistema das causas de justificação. Maurach e Zipf ${ }^{46}$ defendem quc o consentimento é um corpo estranho às causas de justificação, pois nele não vige o principio da ponderação de bens. O principio da ponderação de bens é aquele comum às causas de justificação, e dá-se através da comparação do tipo, do valor e da importância do bem em concreto, verificado em uma situação real.

Assim ocorre na legítima defesa. na qual, dada uma determinada situação em concreto, a antijuridicidade da conduta é excluida, pois apurado que a integridade física do agressor é um bem menos relevante do que a vida daquele que se defende. Portanto, para que determinada causa de justificação seja eficaz, é necessária uma ponderação entre o bem lesado e o bem assegurado através da lesão, com a conseqüente verificação de que o bem lesado apresenta valor ou importância menor do que aquele assegurado.

Maurach e 'Lipf afirmam que no consentimento não há uma ponderação de bens em concreto. A única ponderação que o consentimento permite é aquela abstrata, pois depende da capacidade abstrata de disposição do individuo face à sociedade. Este lipo de ponderação não envolve bens diretamente tutelados por diferentes tipos penais, como a vida (protegida pelo tipo de homicídio, previsto no art. 121 do CP) versus a integridade física (protegida pelo tipo de lesão corporal, previsto no art. 129 do CP), mas a liberdade individual, constitucionalmente assegurada, ${ }^{4}$ versus um ou mais bens penalmente tutelados, tais como a vida, a honra, a propriedade, dentre outros. Já Lenckener e Roxin ${ }^{48}$ defendem que o consentimento não pode ser tido como causa de justificação, pois, ao contrário delas, cle não apresenta um conflito entre ofendido c ofinsor.

Molina Arrubla, ${ }^{49}$ invocando Jimenez de Asua, afirma que as tradicionais causas de justificação, tais como o estado de necessidade, a legítima defesa e o estrito cumprimento de um dever legal ou exercício regular de um direito já são genéricas e amplas o suficiente para abranger todos os casos de exclusão da ilicitude, não se fazendo

\footnotetext{
46 ANDRADE. M. C. Consentimento e Acordo cit., p. 188-190.

47 Cf. art $5^{\circ}$, caput. da CF brasileira.

A8 ANDRADE. M. C. Consentimento e Acordo cit.. p. 258.

49 Revista de la Facultad cit. p. 32.
} 
necessária a criação de uma nova causa de exclusão para a sua aplicação a um ou dois casos concretos.

Esta aferição apresenta-se equivocada, vez que, em primeiro lugar, os casos de consentimento no Direito Penal são bastante freqüentes e complexos, não se resumindo às intervenções cirúrgicas, transplante de órgãos e lesões decorrentes de práticas desportivas. como fa $\angle$ crer o autor. Em segundo lugar, a exclusão da antijuridicidade da conduta através das tradicionais causas de justificação não se apresenta adequada, pois elas "camuflam" o verdadeiro fundamento da exclusão, qual seja. o consentimento.

Na verdade, somente em alguns poucos casos a questão poderá ser resolvida pelas tradicionais causas de justificação: quando o consentido agir sob o consentimento c sob uma excludente tradicional, ambos com incidência simultânea. Ex.: Lim um desastre náutico, $\mathrm{A}$ consente que $\mathrm{B}$ o mate para que este último possa sobreviver. Considerando que a morte de $\mathrm{A}$ era o único meio para que $\mathrm{B}$ sohrevivesse, a ilicitude do homicídio por ele praticado pode ser excluída tanto pelo consentimento quanto pelo estado de necessidade justificante, vez que nele incidem ambas as excludentes.

Frente ao posicionamento de parte da teoria monista, que insiste em defender que o consentimento não se amolda ao sistema das causas de justificação, Costa Andrade, ${ }^{50} \mathrm{com}$ acerto, afirma que é sempre o sistema que deve se adequar às causas, e não o contrário. Para ele, o sistema das causas de justificação está entrando em crise, pois o seu discurso tum se inserido cada vez mais ao discurso de política criminal, transcendendo sua análise para além do Direito Positivo, enquanto alguns autores ainda as tratam como meros institutos dogmático-juridicos. ${ }^{51}$ As causas de justifícação devem ser resultado de um surgimento espontâneo, e não-produto de uma construção sistemática.

Afirma o autor que a sistematização das causas de justificação é imprópria, mas há alguns princípios comuns a todas elas, tais como a autonomia pessual, a solidariedade, a responsabilidade, a ponderação de interesses e a estabilização das normas. O consentimento é passível a todos estes princípios. Na verdade, o único aspecto peculiar do consentimento em relação às demais causas de justificação é que, nele, o conflito dá-se entre a autonomia pessoal e a heteronomia social, ou seja, entre o interesse do

so Consentimento e Acordo cit., p. 244-246.

51 "Compreende-se, assim, que a genuralidade dos autores propenda para um afrontamento directo da problemática suscitada pelas singulares causas de justificação, isoladamente consideradas, suspendendo não só a referência mediadora ao sistema, como pondo mesmo intre parênteses o problema do sistema. Um sistema, argumenta-se. de que pouco mais haveria de esperar do que uma homóloga sistematização dos tipos da Parte Especial poderia oferecer para a resposta aos problemas especificos suscitados por cada uma das incriminaçōes. Esta atitude é extensiva quer às chamadas doutrinas monistas - que aspiram a reconduzir lodas as causas de justificação a um único princípio de fundamentação e sistematizaçào quer is chamadas doutrinas pluralistas. que apelam privilegiadamente para hipóteses de sistematizaçăo diferenciada. integrando dois ou mais principios gerais de sistematizaçāo." (grifos do texto). Id.. ibid., p. 242-243. 
consenciente e o interesse da sociedade, e não entre o conflito de interesses de duas pessoas sem mais.

As teorias monistas foram muito importantes na crítica do paradigma dualista de Geerds, provocando seu desenvolvimento, sendo uma das principais inovações por elas trazidas a idéia de autonomia do individuo ou liberdade individual como fundamento do consentimento. Contudo, elas não foram suficientes para suplantar o modelo dualista, e isso porque a autonomia individual ou liberdade pessoal não são os únicos bens passíveis de proteção pelo Direito Penal. Como salienta Amelung, ${ }^{52}$ a liberdade de consentimento é apenas uma parcela da liberdade geral de ação.

\subsubsection{Um novo paradigma dualista}

Analisando ambos os paradigmas, tem-se que o paradigma dualista é mais adequado à teoria do consentimento tanto por razões político-criminais quanto por razões dogmáticas. No que tange à política-criminal, ela traduz-se na impossibilidade de o Direito Penal tutelar tão-somente a autonomia individual, pois se ele foi desvencilhado da vingança pessoal e corporificado na figura do Estado, a fim de promover a ordem social, então não há porque se sobrepor um interesse individual a todo e qualquer interesse social. Lembre-se que o Direito Penal é um Direito Público por excelência, e apresenta como função primordial a proteção de bens importantes à manutenção e ao desenvolvimento da sociedade.

Por outro lado, o Direito Penal também não deve tutelar apenas bens de natureza pública, como defende Molina Arrubla, pois a proteção da autonomia individual é demasiadamente importante para a manutenção da ordem social. Isso porque, sendo a sociedade composta por indivíduos, a segurança de sua liberdade é essencial para a sua inter-relação com os demais, bem como para o reconhecimento do Estado como instituição legítima para a proteção dos bens jurídicos. É a autonomia social que garante a realização da pessoa como tal e, conseqüentemente, sua realização em sociedade, tanto assim que a liberdade individual está expressamente prevista no art. $5^{\circ}$ caput, de nossa Constituição Federal. Portanto, o Direito Penal deve proteger tanto os bens de natureza pública como a autonomia individual, sendo esta última protegida apenas quando assegure a proteção aos bens de natureza pública, ou ao menos que não-obste a sua proteção.

A liberdade individual, expressão mesma da dignidade da pessoa humana, compreende a sua capacidade de autodeterminação, ou seja, o agir conforme sua vontade. Dentre as inúmeras vontades que determinada pessoa apresenta em relação a um bem

Id., ibid., p. 199. 
juridicamente relevante, a principal delas é a disposição deste bem, ou seja, a sua deterioração ou destruição, sem que disso advenha uma responsabilidade penal a ela ou a terceiro. A capacidade de disposição só é assegurada na medida em que, através de sua autonomia individual, a pessoa renuncie à proteção do bem jurídico sem que disso advenha uma responsabilidade penal.

Neste contexto, tem-se que o Direito Penal pode proteger tanto os bens tradicionais, denominados aqui de bens em espécie. como a autodeterminação da pessoa sobre a disponibilidade destes bens, chamada de liberdade de disposição. Por exemplo, o Estado pode proteger tanto a integridade física em si quanto a liberdade de disposição, pela pessoa, de sua integridade fisica. Entende-se aqui por bens em espécie todos aqueles bens que não a liberdade de disposição pela pessoa. São exemplos de bens em espécie a vida, a honra, a propriedade, a integridade física, o Erário Público, a administração da Justiça e outros, exceto a capacidade de disposição, pela pessoa, da vida, da honra, da propriedade, e destes outros.

Quando o Direito Penal tutela a capacidade de disposição de bens pelo indivíduo, o consentimento não importa em lesão ao bem penalmente protegido. Ao contrário, significa a própria expressão e realização deste bem. Aqui, o consentimento é analisado na esfera da tipicidade. como fator de exclusão da própria lesão ao bem penal. Já nos tipos em que o Direito Penal tutela não a capacidade de disposição de bens pelo indivíduo, mas os bens em espécie em si mesmos considerados, então o consentimento não exclui a lesão ao bem, devendo ser discutido na esfera da antijuridicidade, como seu fator de exclusão.

Dai a preferência pelo paradigma dualista, que melhor se ajusta aos valores prevalentes na sociedade. Tem-se um consentimento excludente do tipo, nos tipos em que o Direito Penal tutela a liberdade de disposição de bens pelo indivíduo, e um consentimento excludente da antijuridicidade, nos tipos em que o Direito Penal tutela os bens em espécie. Tal paradigma é mais apropriado, pois permite que o Direito Penal tutele ao mesmo tempo tanto a capacidade de disposição pela pessoa, que é a expressão máxima da autonomia individual e. conseqüentemente, da dignidade da pessoa humana, quanto os bens de natureza social, aqui chamados de bens em espécie, conforme a necessidade e conveniência da situação típica.

O paradigma dualista também é vantajoso porque, ao permitir a discussão do consentimento na esfera da antijuridicidade, possibilita a ponderação dos interesses individuais e sociais, estabelecendo limites claros e definidos para a sua eficácia. $O$ paradigma monista, por contar tâo-somente com a discussão do consentimento na esfera da tipicidade, é obrigado a criar mecanismos de escape que possibilitem este confronto 
entre os interesses individuais e sociais. Dentre tais mecanismos, o mais conhecido são os bons costumes de Roxin, ${ }^{53}$ que sc apresentam como limiles nebulosos e impróprios à eficácia do consentimento.

Por certo, o paradigma dualista é mais vantajoso que o monista pelos motivos acima elencados. No entanto, a clássica divisão entre acordo e consentimento é imprópria, não se fazendo adequada ao Direito Penal contemporâneo, vez que se apresenta muito rígida e inflexivel à nova mobilidade que a teoria da imputação objetiva atribui à matéria. Ao invés de um acordo e de um consentimento, melhor falar-se em um consuntimento-atipicidade e em um consentimento-justificação.

Ambos, consentimento-atipicidade e consentimento-justificação, são modalidades de um todo, do consentimento, pois significam a manilestação de vontade do consenciente sobre ingerência em seus bens juridicos por outrem. Além disso, apresentam a mesma definição e natureza, bem como os mesmos requisitos de existência, validade e eficácia, razão pela qual não devem ser divididos e classificados como instituições autônomas. É verdade que o consentimento apresenta funções diferentes, excluindo ora o tipo e ora a antijuricidade penal, mas esta diferença ocorre apenas com relaçãu a sua função, não havendo motivos para cindi-los em dois institutos distintos.

O consentimento-atipicidade não é igual ao acordo, e o consentimentojustificação não é igual ao consentimento. Diversamente do acordo, o consentimentoatipicidade pode ocorrur tanto nos tipos que apresentam o dissenso como scu elemento integrante quanto naqueles em que isso não-ocorre. O fator determinante será se o tipo tutela a liberdade de disposição de bens pelo indivíduo.

$\mathrm{O}$ acordo ocorre apenas nos tipos em que o dissenso entre autor e vitima constitui seu elemento integrante, pois presume que apenas eles tutelam a liberdade de disposição de bens pelo individuo. Esta presunção não pode ser feita, pois a liberdade de disposição de bens pode ainda abarcar os tipos que não apresentam o dissenso como elemento integrante, como nos lipos de perigo de contágio venéreo (art. 130 do CP), de perigo de contágio de moléstıa grave (art. 131 do CP), de lesão corporal leve (art. 129. caput, do CP), de difamação (art. 139 do CP), de injúria (art. 140 do C.P), de dano (art. 163 do $\mathrm{CP}$ ), dentrc inúmcros outros. Estes tipos tutelam não os bens em espécie, mas a liberdade de disposição destes bens pelo indivíduo.

Quem determina o tipo de bem tutelado (hens em espície ou liberdade de disposição de bens pelo individuo) é própria sociedade, através de seu agir comunicativo. Veja-se a perfuração do corpo para a colocação de piercings, algumas delas gerando lesões corporais considerávcis. Tal atitude é extremamente normal na sociedade brasileira.

Derecho penal cil., p. 520 e 529-530. 
e até mesmo incentivada pelos jovens e pela midia. Neste caso, o consentimento faz com que a lesão ao bem juridico integridade fisica não seja típica, pois o tipo de lesão corporal tutela a liberdade de disposição, pelo individuo, de sua integridade física, e não a integridade física em si considerada.

Da mısma forma, o consentimento-justificação não equivale ao consentimento. Diversamente do último, o primeiro tem lugar em todos os tipos que tutelam os bens em si considerados. Todos os tipos que não tutelam a capacidade de disposição de bens pelo individuo tutelam os bens em espécie e, portanto, são objetos do consentimento-justificação.

Com a divisão do consentimento em consentimento-atipicidade e em consentimento-justificação, o critério de análise sai do dissenso como elemento estrutural do tipo e recai no tipo de bem tutelado - liberdade de disposição de bens pelo indivíduo ou bens em espécie. Isso permite maior flexibilidade na divisão, pois a elcição do tipo d心 bem protegido pelo tipo penal será feita pela sociedade, através de seu agir comunicativo, ¿ não pela rígida estrutura normativa.

Diversamente do que defendem as teorias monistas, o consentimento não é estranho às causas de justificação tradicionais. Primeiro porque, como elas, envolve um conflito de bens ou interesses. A única diferença é que nas causas de justificação tradicionais o conflito dá-se no âmbito intra-sistêmico, entre ofendido e ofensor, enquanto que no consentimento o conflito dá-se no âmbito intersistêmico, entre o sujeito consenciente (ofendido) e a sociedade. Esta diferença, por si só, não é apta a retirar a natureza justificante do consentimento.

Além disso, não são as causas de justificação que devem se amoldar ao sistema. Ao contrário, este último deve ser erigido levando em conta as causas de justificação existentes. Considerando que o requisito primordial destas últimas é a exclusão da antijuridicidade da conduta típica, e que o consentimento, dependendo do bem ou do interesse protegido, apresenta esta propriedade, entào ele pode ser incluido no sistema das tradicionais causas de justificação.

\subsection{O consentimento no Dircito Penal brasileiro}

O Código Penal brasileiro não trata do consentimento do ofendido, deixando-o a cargo da doutrina. Esta, seguindo os moldes positivistas, apresenta-se bastante tímida ao tratar da matéria, entendendo-o, em geral, como causa de cxclusão do 
tipo ou como causa supralegal de justificação, ${ }^{54}$ estando a última restrita aos bens disponiveis e a casos específicos. Autores como Nelson Hungria ${ }^{55}$ chegam mesmo a negar a eficácia do consentimento sob qualquer hipótese, dada a natureza pública do Direito Penal e a incapacidade de o ofendido decidir sobre a ingerência em seus bens juridicamente relevantes por outrem.

Assis de Toledo, ${ }^{56}$ filiado à teoria dualista, afirma que o consentimento pode assumir várias funções na área penal, surgindo ora como elemento essencial do tipo, (ex.: rapto consensual - art. 220 do C.P). ora como excludente de tipicidade (ex.: apropriação indébita - art. 168 do CP), ora como causa de justificação (ex.: crime de dano art. 163). e ora como fator irrelevante ao Direito Penal. não apresentando qualquer eficácia (ex.: homicídio art. 121 do CP). O consentimento será causa de exclusão da tipicidade quando excluir o dissenso da vítima, se este constituir elcmento essencial do tipo. Será causa de justificação quando excluir a antijuridicidade da conduta, desde que o bem objeto do consentimento seja disponivel pela vítima.

$\mathrm{O}$ autor ressalva que o consentimento dado nas intervenções cirúrgicas. desde que realizadas de acordo conı os procedimentos médicos recomendados, não deve ser entendido como causa de justificação. Isso porque a conduta é naturalmente atípica, pois não se faz danosa, mas em beneficio de quem a aproveita. A questão é mais complexa e envolve casos de cirurgias de alto risco. feitas não para salvar a vida do paciente, mas para corrigir uma grave deficiência que, por si só, não põe a cobro a sua vida. Ex.: cirurgias em paraplégicos para a correção da deficiência. Daí a necessidade de análise da tipicidade, mas sob a ótica do risco permitido, não excluindo o estudo, no caso, da eficácia do consentimento.

Regis Prado, ${ }^{57}$ também adepto da teoria dualista, defende que 0 consentimento pode ser causa de atipicidade ou de justificação. O primeiro ocorre nos tipos delitivos que protegem, simultaneamente, um determinado bem juridico e a liberdade de disposição sobre este bem. Aqui. sua doutrina aproxima-se daquela de Stratenwerth. Regis Prado também afirma que o consentimento excludente de tipicidade

$\therefore$ TOLEDO. F. A. ibid. p. 171-172. "É que as causas de justificação. ou normas permissivas, não se restringem. numa estreita concepção positivista do direito, às hipóteses expressas en lei. Precisam igualmente estender-se àquelas hipóteses que, sem limitações legalisıs, derivam necessariamente do direito vigente e de suas fontes. Além disso, como não pode o legislador prever todas as mutações das condições materiais e dos valores ético-sociais. a criação de novas causas de justificação. ainda não traduzidas em lei, torna-se uma imperiosa necessidadc para a correta e justa aplicação da lei penal. Assim, por exemplo, como recusar efeito excludente da ilicitude ao consentimento expresso do ofendido. $\mathrm{cm}$ relação aos danos que atingem bens plenamente disponiveis?"

55 Id., ibid.. p. 172.

56 Id., ibid.. p. $214-215$.

57 Curso de' Dircito Penal cit. p. 332-335. 
exige como requisito do tipo que a conduta se realize contra a vontade do sujeito consenciente.

Já a consentimento como causa de justificação ocorre quando o sujeito consenciente renuncia a tutela do bem jurídico disponível nos tipos que não apresentam o dissenso da vítima como seu elemento integrante. $O$ consentimento justificante reside no princípio da ponderação de valores, que ocorre sempre a partir do confronto entre a liberdade de disposição individual e o desvalor da ação e do resultado típicos.

Pirangeli, ${ }^{58}$ igualmente dualista, defende que o consentimento pode ser causa de exclusão do tipo ou dá antijuridicidade. Será causa de exclusão nos tipos que apresentam o dissenso como seu elemento dircta ou indiretamente integrante. Havendo consentimento, o tipo não se configura, não ocorrendo o crime. O autor ressalta que em alguns tipos é o consenso, e não o dissenso, o elemento integrante do tipo. de forma que eles não se configuram se não verificado o consenso. O consenso será causa de justificação nos delitos que não prevêem o dissenso da vítima como seu elemento integrante.

$\mathrm{O}$ autor atïrma ainda que o consentimento do ofundido pode figurar como causa de exclusão de antijuridicidade apınas nos delitos em que o único titular do bem protegido é aquele que aquiesce. Tais delitos podem lesar quatro tipos de bens, quais sejam, os bens patrimoniais, a integridade física. a honra e a liberdade individual. $O$ consentimento será válido somente em relação aos bens patrimoniais, à integridade moral e à liberdade individual, vez que apenas estes são disponíveis pelo ofendido.

Por fìm, Chaves Camargo. ${ }^{59}$ também filiado à teoria dualista, aliando o consentimento à teoria da imputação objetiva, defende a existência de um acordo. com a conseqüente exclusão da tipicidade, e de um consentimento, com a exclusão da antijuridicidade. Ocorrerá acordo toda vez que o dissenso do ofendido for elemento integrante do tipo, e consentimento toda vez que o dissenso não for seu elemento integrante. Assim, "o consentimento tanto pode excluir o tipo, quando extcriorizado para a realização típica, como a antijuridicidade, quando o ofendido admite o dano ao bem juridico, de forma clara e expressa" 60

Chaves Camargo introduz a idéia do agir comunicativo entre ofensor e ofendido, bem como a da autocolocação em risco da vítima. Esta última ocorre quando o incremento do risco é causado pela própria vítima. e serve de fundamento para a diminuição ou exclusão da responsabilidade penal do agente quando do consentimento do

\footnotetext{
58 O consentimento do Ofendido cit., p. 96-103.

Imputação Objeriva cit., p. 180-184.

60 CAMARGO, A. L. Chaves, ibid., p. 182.
} 
ofendido. A autocolocação em risco deve ser estabelecida em termos claros e objetivos, vez que não há um interesse em descubrir o aspecto subjetivo dos partícipes do agir comunicativo, mas em analisar a exteriorização do fato concreto. Fstas novas idéias são provenientes da teoria da imputação objetiva adotada pelo autor.

De forma geral, a doutrina brasileira, de base positivista, limita-se a diferenciar o consentimento excludente da tipicidade daquele excludente da antijuridicidade, sendo o último estritamente reservado aos bens totalmente disponiveis pelo sujeito consenciente. Isso retira grande parte da eficácia do consentimunto como causa de justificação, vez que somente alguns poucos bens, tais como a propriedade, a integridade moral e a liberdade individual, são entendidos como passiveis de disposição pelo indivíduo.

A teoria da imputação objetiva, com a inserção do agir comunicativo, da teoria do risco e da auto-responsabilidade da vítima, pode ser um grande contributo para a extensão da eficácia do consentimento a um número muito maior de situações, preservando a capacidade de disposição de bens do individuo, evitando injustiças e adequando-se melhor à teoria do delito.

\section{Imputação objetiva}

3.1. O causalismo e a necessidade de uma nova teoria da imputação

Por se configurarem apenas com a existência do resultado lesivo, os crimes de resultado apresentam uma peculiaridade em relação aos demais, pois só podem ser atribuidos ao agente se entre a sua conduta e o resultado houver um nexo causal. Esta tarefa é bastante árdua em determinados casos. gerando inúmeros debates sobre a seguinte indagação: qual a melhor forma de atribuição de um resultado lesivo a determinada pessoa?

A primeira rusposta surgiu com as teorias da causalidade, mais precisamente com a teoria da equivalência das condições. ${ }^{61}$ Desenvolvida pelo processualista austríaco (ilaser em $1858,{ }^{62}$ ela considera causa toda condição sem a qual não se produz o resultado lesivo, sendo equivalentes todas as condições aptas a produzirem o resultado, daí derivando a denominação "equivalência das condições" Utiliza o método analítico-sintético, que limita toda a investigação à observação empírica

\footnotetext{
6) Id., ibid., p. 55-60.

62 Id. ibid., p. 47.
} 
e ao raciocinio lógico-formal, não havendo valoração da conduta. mas apenas o estabelecimento do nexo causal entre ela e o resultado.

Para saber se determinada conduta foi causa do resultado lesivo, a tcoria da equivalência das condições traz a fórmula da supressão mental, também conhucida como conditio sine qua non, utilizada pela primeira vez por BURI ${ }^{63}$ e que consistc no scguinte: se suprimindo a condição suprime-se o resultado, então esta condição também é causa do evento. Exemplificando: em um acidente automobilistico, se suprimindo a ação do motorista o acidente continuar existindo, então sua conduta não é a causa do acidente. Se, entretanto, suprimindo a sua conduta o acidente tambím desaparece, então ela é causa do evento.

Embora fosse e ainda seja extremamente importante para o reconhecimento do nexo causal, a tenria da equivalência das condições apresenta várias vicissitudes. A primeira delas refere-se à causalidade hipotética, como no clássico exemplo do fuzilamento: aplicando-se a fórmula da equivalência das condições, pode-se afirmar (erroneamente) que a conduta de cada um dos participantes não foi a causa do resultado morte, vez que suprimindo a sua conduta o resultado continua ocorrendo. Ėsta afirmação é totalmente equívoca, pois i certo que a conduta cle cada um dos fuzileiros loi causa do fuzilamento. Não o admitir significa afirmar que a morte do fuzilado ocorreu sèm causa.

O mesmo diga-se em relação à causalidade alternativa, ilustrada no exemplo em que duas pessoas. $A$ e $B$, concomitantemente e sem saber. ministram doses de vencno à determinada vítima $\mathrm{C}$, que vem a morrer. Sabendo-se que cada uma das doses tinha a potencialidade de matar $C$, então o caso também não pode ser resolvido pela fórmula da equivalência das condições, pois suprimindo-se a ação de $\mathrm{A}$ ou de $\mathrm{B}$ o resultado morte continua existindo. Contudo. é evidente que o resultado foi causado pela conduta dos agentes.

Outro problema refere-se à causalidade nos cursos causais salvadores, ou seja, nos casos em que determinada pessoa interrompe o salvamento de outra, posta em risco por fatores alheios. Segundo a teoria da equivalência das condições, suprimindo-se a ação daquele que interrompe o salvamento. como no caso do afogamento em que $A$ impede que $B$ se dirija com o barco para o salvamento de $C$, o risultado lesivo pode ounão ocorrer, pois B poderia não conseguir salvar A. Entretanto, é evidente que a conduta de A também foi causa do resultado morte, tanto que a doutrina considera o crime como consumado. desde que o curso causal salvador se mostre eficiente para o salvamento.

63 Cf. ROXIN, C. Derecho penal cit., p. 349. 
A maior crítica qui se faz ${ }^{64}$ sobre a țoria da equivalência das condições diz respeito ao regresso ao infinito. Por exemplo, no homicídio cometido por $\mathrm{B}$ em relação a A. a causa do resultado morte não foi apenas o tiro que o primeiro desferiu no segundo, mas também a pessoa que fabricou a arma, aquele que a vendeu a $\mathrm{B}$, os pais de $\mathrm{B}$, por o terem gerado etc. Todas estas condições, se suprimidas mentalmente, fazem com que a morte de A desapareça. Contudo, a punição de todas as pessoas que contribuíram para o evento é, além de impossivel, absurda, pois contraria importantes fundamentus do Direito Penal, tal como o da individualização da pena.

A questão do regresso ao infinito foi parcialmente resolvida por Frank. "segundo o qual somente deveriam ser levados em conta os fatores concretos para a determinação do resultado" " ${ }^{\circ 5}$ A teoria da equivalência das condições apresentou enormes óbices, tais como a dificuldade quanto ao estabelecimento dos limites à causalidade e a aplicação restrita da fórmula da supressão mental, que não era, pois, absoluta.

A doutrina ${ }^{66}$ acabou por perceber que a teoria da equivalência das condições era necessária, mas não suficiente. para o estabelecimento do nexo causal. Esta insuficiência deve-se principalınente à natureza empírica e lógico-formal da fórmula conditio qua non, que não conseguiu estabelecer limites à identificação das causas. Diante disso, surgiu uma nova teoria para resolver a questão da causalidade: a teoria da causalidade adequada, ou teoria da adequação.

\subsection{A teoria da causalidade adequada}

A teoria da causalidade adequada ou da adequação ${ }^{67}$ foi proposta inicialmente por Bar, em 1871, e posteriormente por Kries, em 1886 e 1888, apresentando significativos efeitos na esfera penal. Para ela, "causa é somente aquela que. de acordo com as regras gerais da vida e experiência geral seja, como condição, adequada para a produção de determinado resultado" "68 A teoria da causalidade adequada negava a

CAMARGO. A.L. Chaves. Imputaçăo Ubjetiva cit., p. 54.

Id. Ibid., p. 54.

66 Com exceção de C. ROXIN. Derecho penal cit., p. 350, segundo o qual a teoria da equivalência das condições não apenas é inútil, como também pode levar a erros, cumo nos casos de causalidade alternativa e hipotética. Tem-se, todavia, que a teoria da equivalência das condições é a teoria da causalidade que melhor reconhece o nexo causal, sendo inclusive muito importante à teoria da imputação objetiva, que necessita sempre de um pressuposto causal para ser aplicada.

67 CAMARGO. A.L. CHAVES. Imputação Objeriva cit., p. 55-57.

68 Id., ibid., p. 54. C. ROXIN, em sua obra derecho penul cit., p. 360. coloca que, "una condición es adecuada (o sea, adaptada al resultado) si la misma ha aumentado la posibilidad del resultado de modo no irrelevante. si no es sencillamente inverosimil que la conducta dé lugar a un resultado asi." 
causalidade das condições que antes do evento não ofereciam perigo em relação ao resultado típico.

O juizo de adequação era feito a partir de um prognóstico objetivoposterior: o juiz, posteriormente à ocorrência do fato, colocava-se na posição de um terceiro (homem médio) e fazia uma análise como se o fato ainda não houvessc ocorrido, verificando se a ação era ou não adequada naquelas circunstâncias. A teoria da adequação era benéfica por três motivos: i) excluía as condições nas quais o autor havia produzido o resultado de forma imprevisível e sem culpa; ii) eliminava os nexos causais totalmente não usuais, evitando assim o regresso ao infinito e; iii) permitia a exclusão dos cursos causais extravagantes (aventureiros). ${ }^{69}$

A teoria da adequação não era propriamente uma teoria causal, mas uma teoria da imputação. Fla procurava não a causa do resultado. mas se ele era juridicamente relevante. Além disso, como a adequação da causa relacionava-se diretamente à adequação da ação, a teoria confundia causalidade com culpabilidade, aproximando-se muito mais de uma imputação valorativa do que de uma relação de causalidade.

Mesmo em se tratando de uma teoria da imputação, a causalidade adequada não apresentou critérios claros de exclusão da responsabilidade, pois algumas condutas que envolviam certos cursos causais hipotéticos ou regresso ao infinito, apesar de socialmente adequadas, não podiam ser imputadas. Isso levou à necessidade de uma nova teoria da imputação.

\subsection{A teoria da relevância}

A teoria da relevância ${ }^{70}$ surgiu no início do século $\mathrm{XX}$ e foi influenciada pelo positivismo jurídico, desenvolvido pela Escola Suocidental Alemã. Proposta por Mezger em 1921, ela defendia que a responsabilidade não era composta apenas pela causalidade, propondo uma análise valorativa do tipo penal. Afirmava também que o nexo causal, por si só, não conduzia à responsabilidade juridico-penal, pois não significava a equivalência juridica. Daí a necessidade de as condições serem analisadas em relação ao tipo penal. para que se averiguassem quais as relevantes ao Direito Penal. A teoria da relevância mostrou-se contraditória pois introduziu uma nova concepção valorativa do tipo, mas manteve a essência do sistema clássico.

\footnotetext{
69 ROXIN. C. Derecho penal cit., p. 359-300.

70 CAMARGO, A. L. Chaves. Imputução Objetiva cit., p. 58-60.
} 


\subsection{A teoria da adequação social}

Também o finalismo ${ }^{71}$ se insurgiu contra as teorias causais, e isso devido à sua concepção de conduta típica. Para a doutrina finalista, toda ação é impulsionada pela vontade do agenle que pretende, a partir dela, atingir determinado resultado, não se podendo falar em ação quando a conduta não se dirige à produção do resultado efetivamente alcançado. Como todo resultado produzido sem vontade não é ação, ele não pode ser imputado ao agente, o que gera a desnecessidade da utilização das teorias causalistas. Ressaltc-se que a concepção finalista prima pelo desvalor da ação, não do resultado.

A teoria finalista é bastante adequada aos delitos dolosos, mas apresenta certa dificuldade em fundamentar a responsabilidade nos delitos culposos, pois estes últimos são produzidos sem a vontade do agente. É verdade que o finalismo fundamenta o crime culposo não na vontade de produção do resultado. mas na inobservância do dever de cuidado, procurando assim manter a idéia de desvalor da ação. Mesmo assim, ela continua sendo falha, pois permite a responsabilização do agente nas situações em que o resultado seria produzido mesmo com a observância do dever de cuidado.

Por exemplo: um molorista está dirigindo em uma rodovia em velocidade acima da permitida quando atropela um suicida, que acaba por morrer. Se comprovado que mesmo dirigindo na velocidade permitida o suicida morreria ao atirar-se no carro, então a responsabilização do condutor do veiculo é injusta, mas devida, pois ele infringiu um dever de cuidado, causando um resultado lesivo.

Tentando corrigir estas imperfeições, Welzel, em 1939, apresentou a teoria da adequação social:

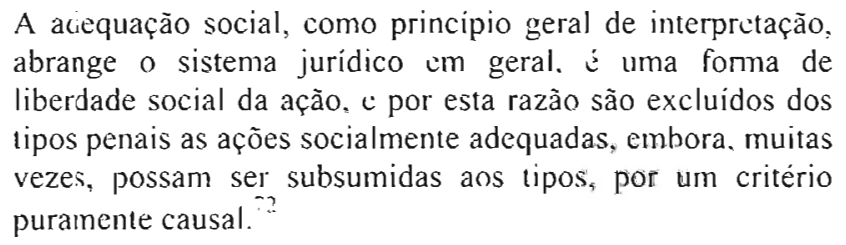

De acordo com esta teoria, só podem ser atribuidas ao agente as ações socialmente inadequadas, ou seja, aquelas que ultrapassam os limites da liberdade de ação, estabelecidos pela socicdade.

Tal como as dumais, a teoria da adequação social apresenta algumas vicissiludes. Uma delas refere-se à dificuldade $\mathrm{cm}$ se estabelecer o que é socialmente

\footnotetext{
71 Id.. ibid.. p. 64-66.

72 Id., ibid. p. 67-69.
} 
adequado. Outra se refere à sua inabilidade em resolver alguns problemas de atribuição do resultado, como no célebre caso do sobrinho que leva o tio a um bosque constantemente atingido por raios, com a finalidade de matar o último, que acaba morrendo em decorrência da descarga elétrica. Neste caso, Welzel tenta afastar a atribuição típica pela ausência de dolo, ao afïrmar não haver a vontade com o poder de influenciar que o dolo exige. ${ }^{3}$ Sua fundamentação parce incorreta, pois é evidente a intenção do sobrinho em matar o tio. O problema é muito mais de causalidade do que de dolo, e mostra que o último não consegue exercer todos os limites exigidos pelo Direito Penal.

Schünenmann afirma que a teoria da adequação social é capaz de resolver somente os casos socialmente adequados, excluindo aqueles em que o resultado é tardio, como na Aids ou na morte ocorrida alyum tempo após a provocação do acidente. As ações com resultado tardio são socialmente adequadas, porque o agente não apresenta influência sobre o tempo que decorre desde a ação inicial até o resultado lesivo.

As incongruências das teorias apresentadas fizeram com que a doutrina procurasse uma nova teoria da imputação, proporcionando o surgimento da teoria da imputação objetiva.

\subsection{A evolução da teoria da imputação objetiva}

Foi I arenz. em 1927, quem primeiro desenvolveu a teoria da imputação objetiva, cuja aplicação era voltada ao Direito Civil, estabelecendo limites entre os fatos próprios e os elementos acidentais. Sua teoria fundamenta-se na vontade do ser racional que, prevendo as conseqüências de suas ações, direciona o seu comportamento. Assim, "se não há imputação do fato ao sujeito, este não pode ser considerado como uma causação de resultado, e, portanto, não existe a própria ação, pois tudo é produto de um acidente" 74

Fm 1930, Honig ${ }^{75}$ propôs a teoria da imputação objetiva ao Dircito Penal, excluindo a responsabilização de base exclusivamente causal e estabelecendo um juízo de imputação autônomo, de base teleológica, no qual o resultado é sempre determinado pela finalidade da conduta do agente. Para ele, a conduta humana será relevante ao Direito Penal somente se. além de causalidade, ela apresentar uma linalidade específica acrescida a esta última. O desvalor encontra-se no resultado, não na ação.

ROXIN, C. Strafrecht cit., p. 362.

C.AMARGO, A. L. Chaves. Imputaçào Objetiva cit., p. 62.

Id., ibid., p. 63-64. 
Nos anos 70, Roxin, ${ }^{76}$ a partir da teoria de Honig. deu um passo decisivo para a teoria da imputação objetiva, ao afirmar que o resultado lesivo somente pode ser imputado ao agente quando produzido através de uma ação finalisticamente orientada a criar um risco juridicamente desaprovado, refletido no resultado típico. Roxin elegeu o risco juridicamente desaprovado como um importante critério de imputação, seguido e desenvolvido por inúmeros outros estudiosos. Além de Roxin. vários outros doutrinadores adeptos da teoria da imputação objetiva destacam-se atualmente, tais como Jakobs e Jeschıck, por apresentarem novos critérios de imputação ou desenvolverem aqueles então existentes.

Tem-se que a imputação objetiva í a forma mais completa c flexivel de atribuição do resultado lesivo ao agente. Completa porque pressupõe a relação de causalidade, mas aí não se esgota, envolvendo critérios normativo-valorativos de atribuição, tal como o incremento do risco. Também completa porque resolve problemas de atribuição que nenhuma outra teoria, seja ela causalista ou de imputação, consegue resolver, como os cursos causais hipotéticos ou alternativos, a interrupção dos cursos causais salvadores, o regresso ao infinito, os cursos causais que apresentam um grande intervalo entre a conduta e o resultado lesivo, dentre inúmeros outros.

Flexivel porque não-fundamentada em uma visão empírica, lógico-formal. naturalística, mas normativo-valorativa, argumentativa. Isso permite que a atribuição do resultado lesivo saia da esfera restrita da causalidade para alcançar os valores socialmente relevantes, depreendidos através do agir comunicativo entre os atores sociais e traduzidos nos respectivos tipos penais. Em última instância, a imputação objetiva permite que o resultado seja atribuído segundo os próprios fins do Direito Penal. Dai seu caráter teleológico.

Por não estar vinculada a uma análise meramente empírica e lógico-formal. a teoria da imputação objetiva é tão flexivel que permite a discussão do próprio critério de imputação. O critério do incremento do risco, proposto por Roxin, tem se mostrado adequado aos fins perseguidos pelo Direito Penal contemporâneo, bem como suficiente para resolver os problemas de imputação até então surgidos, apresentando-se como o principal critério de imputação. Contudo, nada obsta que, verificada a sua incompatibilidade com o Direito Penal no futuro, ele venha ser modificado ou substituído por outro.

76 Id., ibid., p. 72-80. 
3.6. Teorias da imputação objetiva

\subsubsection{A teoria de Roxin}

Para Roxin, ${ }^{77}$ a imputação objetiva compreende très estágios: i) a existência de um nexo causal entre a conduta do agente e o resultado lesivo; ii) o incremento de um risco socialmente não permitido; e iii) a abrangência deste risco pelo âmbito de proteção da norma penal.

A primeira etapa para que determinado resultado seja objetivamente imputado ao agente é a existência do nexo causal entre a sua conduta e o resultado lesivo descrito na norma típica. Esta relação causal é verificada através da teoria da equivalência das condições, pela aplicação da formula da conditio sine qua non.

Fm seguida, tem-se a análise do incremento do risco, que constitui o elemento mais importante da teoria. apresentando-se como o principal critério de imputação. Em linhas gerais, há incremento do risco quando o agente realiza uma conduta juridicamente relevante, superando as expectativas de risco socialmente aceitas em grau tão elevado que passa a ser proibida pelo sistema penal.

Roxin define o risco permitido como:

(...) una conducta que crea un riesgo juridicamente relevante, pero que de modo general (independientemente del caso concreto) está permitida y por ello, a diferencia de las causas de justificación, excluye ya la imputación al tipo objetivo. ${ }^{78}$

Toda ação humana pressupõe determinado risco. Ao rcalizar uma corrida, qualquer pessoa pode ter uma parada cardíaca e morrer. Ao utilizar uma faca, a pessoa pode se machucar. Da mesma forma, ao fazer uma escalada, ela pode sofrer graves lesões, vindo mesmo a perder sua vida. Todas estas ações estão dentro do risco permitido pela sociedade, ou seja, todas elas pressupõem um risco que a sociedade aceita e em algumas vezes até estimula. As condutas que geram um risco socialmente não-quisto são tipificadas, sendo repelidas pelo Direito Penal.

Para que haja imputação é necessário que a conduta do agente gere um risco acima daquele tolerado pela sociedade, e que o resultado lesivo seja provocado por este incremento do risco. Assim, a morte de A só poderá ser imputada a B se este, através de sua conduta (aplicação de golpes de faca em A), gerar um risco socialmente reprovado (aumento do risco de morte fora dos casos permitidos), provocando o resultado morte.

77 ROXIN, C. Derecho Penal cit., p. 362-380

'y Id., ibid., p. 371. 
Nos delitos culposos o risco é criado pela inobservância do dever de cuidado. Excmplificando: a cunduta de dirigir um carro é comum nas relações sociais. Mas dirigir um carro em desrespeito às normas de trânsito, especialmente àquelas que proibem a passagem no farol vermelho ou o excesso de velocidade, em muito aumenta o risco de um acidente automobilístico, podendo ocasionar lesões corporais ou a morte. Condutas como esta produzem um risco fora daqucle comum ao tráfego de veículos, sendo proibidas pelas normas penais e gerando a exigência de responsabilização do agente.

Há alguns casos em que as normas de cuidado não são capazes de evitar a produção do resultado. Isso faz com que ele não possa sur imputado ao agente. mesmo que o último não as tenha observado, pois elas não cumpriram o seu fim de proteção, que é a limitação do risco a níveis permitidos. Por exemplo: O diretor de uma fábrica de pincéis deixou de esterilizar os pêlos de cabra utilizados para a sua fabricação. contrariando as normas técnicas de procedimento. Alguns funcionários morreram em decorrência da infecção causada pelos bacilos presentes nos pêlos, os quais a esterilização pretendia extinguir. Se comprovado que a infecção pelos funcionários ocorreria mesmo após da esterilização, pois os bacilos eram desconhecidos no país, então o diretor da fábrica não poderia ser imputado pela morte dos funcionários, pois neste caso a norma de cuidado (esterilização dos pêlos de cabras) não cumpriria sua função de limitação do risco. ${ }^{-9}$

As normas de cuidado, desenvolvidas para os delitos culposos, também podem ser utilizadas nos delitos dolosos. No caso acima. se o diretor tivesse a intenção de matar seus funcionárius, ele responderia apenas por homicídio tentado. vez que o resultado morte não foi gerado pelo incremento do risco que ele provocou. ${ }^{80}$

Id), ibid.. p. 375-378. M. MARTINEZ ESCAMILLA não concorda com tal solução. Para ela, nos casos dos pêlos de cabra, o dirctor da fábrica deveria ser imputado, pois a norma de cuidado pretendia exatamente evitar o ocorrido, qual seja, a morte dos funcionários pela infeç̧ão de bacilos, mesmo que o procedimento não fosse suficiente para tanto. Para ela, "la necesidad de un nexo no conlleva de manera inexorable la relevancia del compontamiento alternativo. Podrá afirmarse que el resultado es la realización de la lesión del deber de diligencia a pesar de que en el caso concreto el comportamiento imprudente creó. Lo contrario también es posible: puede excluirse la imputación objetiva a pesar de la constatación de la evitabilidad o del aumento del riesgo. Lo decisivo será si el resultado es de aquellos cuya producción la norma de cuidado tenia por misión evitar o reducir." Argumenta que o diretor deveria ser imputado porque a teoria da imputaçãu objetiva não considera os cursos causais alternativos, não podendo, portanto, fazer a abstração de que os funcionários morreriam mesmo após a esterilização. La imputación objetiva del resultado - una primera aproximación. in Revista de la Facullad de Derecho de México, México. v.44. n. 193i194, ene/abr. 1994, p. 90-93.

$\therefore$ Id., ibid.. p. 382. Diversamente do que afirma o autor, quando o resultado quisto pelo agente ocorre por motivos alheios à inobservincia do dever de cuidado, a conduta será atípica, e não punida como tentátiva. Isso porque o dolo deve ser analisado somente apos a verificação da imputação do resultado ao agente, não tendo o condão de alterá-la. Se determinada conduta culposa nào é imputável, entâo a mesma conduta, se 
A análise do risco é feita através de uma prognose objetivo-posterior. O juiz, analisando o caso concreto (fato ocorrido), coloca-se na posição de observador e verifica se, no momento da ação, houve um incremento do risco, bem como se o incremento era permitido. O resultado será imputado ao agente se verificado o incremento do risco a um nivel socialmente insuportável.

Roxin coloca que "decidir qué es un peligro jurídicamente relevante no es una cuestón de lógica o de ciencias naturales, sino de valoración políticocriminal, pero ésta conduce a las diferenciaciones expuestas" ${ }^{81}$ Daí a importância da teoria da imputação objetiva, pois ela permite que a atribuição do resultado ao agente siga os valores vigentes na sociedade, depreendidos através do agir comunicativo dos atores sociais.

Mas não-basta apenas a verificação do nexo de causalidade e do incremento do risco para que o resultado lesivo seja imputado ao agente. Roxin defende que a teoria da imputação objetiva exige, como terceiro requisito, que o resultado produzido esteja no âmbito de proteção da norma penal. Os principais casos em que tal não ocorre, apresentando-se como limites à imputação nos delitos dolosos, são: i) a cooperação em uma autocolocação em perigo dolosa; ii) a autocolocação em risco de um terceiro consentida por ele; e iii) a imputação de um resultado a um âmbito de responsabilidade alheio.

A primeira ocorre quando determinada pessoa ajuda outra a praticar condutas muito mais perigosas que o normal, tal como no exemplo em que o traficante fornece grande quantidade de heroína ao dependente, vindo o último a morrer de overdose. Já a segunda ocorre quando uma pessoa se deixa colocar em perigo por outra, sendo ambas conscientes do perigo. Assim ocorre quando o passageiro determina ao motorista que ele dirija a uma velocidade excessiva para que o primeiro possa chegar a tempo em seu compromisso, acabando por morrer devido ao acidente causado pelo excesso de velocidade. Já a terceira ocorre quando a prevenção do resultado lesivo é de responsabilidade de outro, tal como no caso da professora que, por sua conduta culposa, deixa um de seus alunos cair no rio, provocando a morte do bombciro que salvou a criança.

Em todos estes excmplos não haverá imputação pelo resultado morte, pois eles estão fora do âmbito de proteção do tipo de homicídio por involverem a autocolocação em perigo da vítima. $O$ incremento do risco pela vítima pode diminuir ou

dolosa, também não o será. No exemplo apresentado, o resultado lesivo não foi produzido pelo incrementu do risco provocado pelo agente, mas por um risco alheio à sua conduta. Além disso. houve lesão efutiva ao bem jurídico vida. Assim, não há o que se falar em tentativa, mas sim em não imputação.

81 Id., Ibid., p. 370. 
até mesmo excluir a responsabilidade do agente. Alguns autores chegam mesmo a cogitar uma sanção penal à vitima pela sua participação. ${ }^{82}$

A doutrina de Roxin é especialmente importante ao desenvolvimento da tcoria da imputação objctiva, pois introduz a análise do incremento do risco como critério suplementar à relação causal, fazendo com que a imputação ocorra de acordo com os valores sociais então vigentes.

\subsubsection{A teoria de Jescheck}

A doutrina de Jescheck ${ }^{83}$ é importante por apresentar o conceito social de ação, ${ }^{84}$ corrente de pensamento que influencia muitos doutrinadores brasileiros. Para ela, não se pode deduzir um sistema de Direito Penal a partir de alguns poucos principios fundamentais, através de uma dedução lógica. É necessário que o Direito Penal apresente um suporte lógico-formal de base normativa, que coloque as normas a serem obedecidas. e um sistema lógico-matcrial, do qual se depreendem os valores socialmente protegidos, de forma que o último sirva de base para a interpretação do primeiro, e, conseqüentemente. para a elaboração de novas proposições jurídicas.

Para Jescheck, de acordo com a teoria da imputação objetiva:

(...) sólo es objetivamente imputable un resultado causado por una acción humana (en el sentido de la teoria de la condición), cuando dicha acción ha creado un peligro juridicamente desaprobado que se ha realizado en el resultado tipico. ${ }^{85}$

O primciro requisito da imputação objetiva é a existência de um nexo causal entre o resultado lesivo e a conduta do agente. $\mathrm{O}$ autor assevera que há alguns poucos casos nos quais a imputação se verifica mesmo ante a ausência do nexo de causalidade, como nos delitos de omissão imprópria ou nos cursos causais salvadores, mas na grande maioria dos casos a imputação objetiva pressupõe a relação de causalidade.

O segundo requisito de imputação é a ocorrência do incremento do risco em grau socialmente desaprovado, ou seja, acima do risco permitido. Todas as ações

82 Sobre uma breve discussão da aplicação de sançōes punais às vitımas, ver M. CANCIO MELIȦ, ibid.. p.3638.

83 JESCHECK, H.-H. Tratado de derecho penal cit, p. 376-391 e p. 552-558.

84 CAMARGO, A. L. Chaves. Impuração Objetiva cit., p. 33. conceitua o conceito social de ação como: "(...) um comportamento socialmente relevante que se refere à relação do individuo com o mundo que o rodeia $\mathrm{e}$ o afeta por suas conseqüências. Ele abrange todas as formas de comportamento humano que podem ser levadas em conta num juizo de imputação penal. A via negativa, por outro lado, determina a irrelevância de alguns comportamentos para esta mesma imputação juridico-penal"

85 JESCHECK, H.-H. Tratado de derecho penal cit., p. 389. 
pressupõem certo risco, colocando em perigo bens protegidos pelo Direito Penal. Entretanto, algumas delas trazem um beneficio muito grande à sociedade, não devendo ser proibidas, mas antes estimuladas. Fxemplo disso é o tráfego de veículos: mesmo aumentando o risco de lesão da integridade física e até de morte de motoristas e passageiros, o transporte rodoviário é importantíssimo à sociedade, fazendo com que o Estado promova a construção de estradas, a produção de veículos, dentre outros.

Ações perigosas deste tipo são solucionadas em parte pela teoria da adequação social ${ }^{86}$ e em parte pelo risco permitido. De acordo com a teoria da adequação social, por serem estas atividades socialmente úteis, o Estado deve as autorizar e até mesmo estimular, lançando, todavia, normas de cuidado para que o risco não seja incrementado a ponto de criar um resultado lesivo. É por isso que estas atividades necessitam da autorização expressa do Estado para que possam ser exercidas: para que ele fiscalize se as normas de cuidado impostas estão sendo efetivamente cumpridas. Diverso ocorre no caso do risco permitido. Se o individuo gerar um resultado típico através do incremento do risco acima do socialmente permitido, então a ação será típica, pois a conduta perigosa trará mais malefícios que benefícios na ordem social. ${ }^{87}$

De acordo com o autor, são casos de risco permitido: i) as ações arriscadas de salvamento; e ii) as ações que colocam em perigo bens juridicos no interesse geral, do autor ou do ofendido. As primeiras ocorrem, por exemplo, quando o piloto de um helicóptero de salvamento empreende um resgate realizando manobra que, embora necessária, coloca em perigo a própria vida dos acidentados. Já as segundas exigem os seguintes requisitos para que aconteçam: a) a conduta deve ser o único meio para a obtenção da tinalidade legítima; b) o autor deve atuar com a intenção de proteger o interesse; e c) a conduta deve ser o meio adequado para a proteção da finalidade legítima.

Não há imputação nos casos de diminuição do risco, ou seja, quando o risco foi incrementado para que não se realizasse outro maior, como no caso em que A empurra B, causando-lhe lesões leves, para evitar que um objeto caia em sua cabeça. A imputação subsiste no caso dos cursos causais hipotéticos, como naquele em que um terrorista explode um avião que já se encontrava com uma falha mecânica, vindo a cair a qualquer momento. Isso porque ao Direito Penal não é permitido fazer abstrações de possiveis cursos causais, atendo-se à análise do caso em concreto.

86 Segundo H.-H. JESCHECK. "La teoria de la adecuación social constituye um instrumento teorético que permite sustraer del tipo de los preceptos penales correspondientes (en especial relativos a homicidio y lesiones dolosas e imprudentes) acciones que, aunque implican peligro para bienes jurídicos protegidos, resultan imprescindibles para la comunidad". (grifos do texto) lbid., p. 553.

87 Ainda segundo o autor, "Caso de realizarse el peligro inherente al hecho, se cumplirá el lipo de la acción punible y sólo cabrá preguntar si, atendido al legitimo interés perseguido por el autor, resulta permitido excepcionalmente la lesión de interesses ajenos". Ibid., p. 554. 
O terceiro requisito de imputação é o enquadramento do risco juridicamente desaprovado no âmbito de proteção da norma que o agente transgride através de sua ação. Se a vitima de uma tentativa de homicídio, ao permanecer no local do crime, é atingida por um raio e vem a morrer, enlão a morte não pode sur imputada àquele que praticou a tentativa de homicídio, pois não é âmbito de proteção do tipo evitar que pessoas morram em decorrência de raios. Diverso ocorre se a vítima morrer por uma infecção causada pelo estado débil em que se encontrava, devido às feridas provocadas pela tentativa de homicídio. Neste caso, o resultado morte deve ser imputado ao agente.

Não há imputação nas hipóteses de lesão da vítima por um terceiro mediante consentimento, pois neste caso a atuação do agente está fora do âmbito de proteção da norma penal. O mesmo ocorre na autolesão da vítima, exceto se ela ocorrer como conseqüência das ações perigosas de salvamento em que o risco da pissoa a ser salva foi incrementado pela ação de outrem. Neste último caso, a pessoa que incrementou o risco daquela a ser salva deverá ser imputada pelo eventual resultado lesivo sofrido pelo salvador.

Por exemplo: Uma professora deixa culposamente um de seus alunos cair no rio, correndo risco de vida. Apesar de conseguir salvá-lo, o bombeiro acaba morrendo em conseqüência do salvamento. Neste caso, a professora deve ser imputada pela morte do bombeiro, pois foi ela quem incrementou o risco de seu aluno, provocando o salvamento, e, conseqüentemente, o resultado lesivo. ${ }^{8 .}$

Quanto aos delitos culposos, não há imputação quando, inobservada uma norma de cuidado, o resultado teria ocorrido mesmo com a sua observância, pois neste caso a criação do risco foge ao âmbito du proteção da norma penal. ${ }^{89}$ Diversamente, a imputação objetiva deve ocorrer nos casos $\mathrm{cm}$ que o resultado lesivo deu-se exclusivamente pela constituição anormal da vitima, vez que o âmbito de proteção normativa se estende a estes casos.

A doutrina de Jescheck seguiu praticamente os mesmos passos daquela proposta por Roxin, divergindo do autor somente em alguns poucos aspectos. sendo importante no desenvolvimento e disseminação da teoria da imputação objetiva.

\footnotetext{
88 Id., ibid., p. 391. Diversamente, ROXIN sustenta que mesmo neste caso nāo há imputação do resultado, pois o terceiro que incrementnu o risco da pessoa a ser salva não pode influir no salvamento. não podendo evitar o resultado danoso (morte du bombeiro). Derecho penal cil.. p. 399-400.

89 Tal assertiva é contraditória à idèia co autor de que há imputação nos casos de cursos causais hipotéticos.
} 


\subsubsection{A teoria de Jakobs}

Para Jakobs, ${ }^{90}$ todo feito punível apresenta um significado, uma base comunicativa, uma expressão de sentido. A conduta criminosa significa um novo paradigma. um novo estágio de evolução social. Significa também a fragilidade da configuração normativa proposta pela sociedade, que se apresenta como mero acessório dispensável, vez que pode ser livremente burlada. Em contrapartida, a aplicação da pena demonstra que a sociedade não aceita este novo paradigma, pois a conduta punida não integra e nunca integrou a sua configuração, por alterar sua forma além do esperado e do suportável.

Neste contexto. a ação criminosa não-implica uma frustração social ou uma desorientação psicossocial, mas tão somente o desrespeito à norma, desrespeito este que deve ser olvidado com a pena respectiva, a fim de que se mantenha a configuração social vigente. A função do Direito Penal é a garantia da existência da norma através da punição da conduta que a afronta. Em outras palavras, a função do Direito Penal é a garantia da atual configuração da sociedade. Ele deve sempre garantir uma configuração social determinada e pré-existente. Um Direito Penal implantado exclusivamente através de preceitos normativos, sem qualquer harmonia com um substrato material, pode até musmo dar origem a normas revolucionárias, pois se converte em um ordenamento coercitivo extremo.

Para Jakobs, as normas são divididas em dois grupos, quais sejam, as normas do entorno e as normas sociais. As primeiras pertencem ao mundo do ser, motivo pelo qual não podem ser desobedecidas. São as regras da lógica, da matemática e aquelas percebidas através das ciências naturais. A pessoa que não as observa sofre uma conseqüência natural, logicamente perceptível, e apenas a ela dirigida (conseqüência individual).

Como exemplo, cite-se a regra do entorno de que os seres humanos não vivem sem ar. Se uma pessoa impede outra de respirar, a última fatalmente irá morrer. Esta conseqüência foi depreendida através de um raciocínio lógico-formal, e com certeza ocorrerá se a causa (impedir um ser humano de respirar) for verificada.

Já as segundas pertencem ao mundo do dever ser. podendo ser desobedecidas. Ao contrário das primeiras, são regras valorativas e argumentativas, que compõem o universo jurídico. Atingem toda a sociedade, e não apenas o indivíduo, pois necessitam de valoração social para que existam e sejam eficazes. Requerem uma garantia social, não-natural.

90 JAKOBS, G.; STRUENSEE. E. Problemas capirales del derecho penal modirno. Buenos Aires. Hanmurabi, 1998. p. 33-55. 
Por exemplo: a norma juridica que proíbe $\mathrm{A}$ de lesionar $\mathrm{B}$ é uma norma social, vez. que a proibição não se encontra no mundo fático, mas no mundo valorativo, da interpretação. Tanto i assim que se A lesiona B porque deseja que este último sofra, então ele receberá uma punição. Entretanto, se A lesiona B porque necessita defendur-se do ataque deste último, então não haverá punição. Tal alternância de resultado não ė possivel nas normas do entorno.

As normas do entorno não podem ser desobedecidas. Já as normas sociais não devem ser desobedecidas. A resposta contra as primeiras é a impossibilidade, o absurdo. Ex. Não é possível que uma pessoa viva sem respirar. Já a resposta contra as segundas é a aplicação da pena. Ex. É perfeitamente possível que uma pessoa mate a outra por sufocação. ('ontudo, esta atitude é recriminada pelas normas penais, por sur a conduta contrária aos valores que a sociedade quer assegurar. É por isso que a conduta é recriminada com a aplicação da respectiva sanção.

As normas do entorno são utilizadas para que a sociedade conheça o meio onde vive, estabelecendo limites nas esferas externas de seus membros. Já as normas sociais apresentam como função a manutenção da atual configuração da sociedade, prevenindo condutas que a coloquem em risco. As soluções contra as normas do entorno não são típicas, mas apenas imagináveis. Já as soluções contra as normas sociais são sempre típicas. Em determinadas condutas o erro sobre o entorno coloca em risco as próprias relações sociais. Assim ocorre quando uma pessoa conduz seu veículo e, por desatenção, não-perccbe que um pedestre está atravessando a rua, atropelando-o. Neste caso, o crro sobre as normas do entomo gerou uma responsabilidade penal, imposta pelas normas sociais.

Para o autor, a incorrência no tipo por culpa deve ser punida com a mesma gravidade daquela ocorrida por dolo, pois a culpa é apenas um déficit psíquico, e nada mais. O desconhecimento dos elementos do tipo só poderá ser punido com pena mais branda por erro de tipo. ${ }^{y /}$ Tem-se para nós que esta solução não é a mais acertada, pois uma conduta típica produzida mediante a vontade do agente é muito mais reprovável do que aquela produzida sem a sua vontade. Entender de forma diversa significa excluir do tipo a análise do elemento subjetivo, gerando graves injustiças quando da aplicação da pena.

Este posicionamento do autor ocorre em virtude da função que ele atribui ao Dircito Penal, qual seja, a de preservação da configuração social. Sob esta ótica, tanto a conduta culposa quanto a dolosa procura a sua desestruturação. Contudo, deve-se ter em

Id., ibid., p. 39. 
vista que a conduta culposa causa uma agressão menor à configuração social do que a conduta dolosa, pois a primeira é mais esperada e suportável do que a segunda.

Jakobs afirma que tanto o naturalismo quanto o finalismo se pautam no causalismo, ou seja, nas normas do entorno, para procederem à imputação, considerando o significado social da conduta apenas na esfera da antijuridicidade. Entrctanto, o importante para a imputação é o significado que a conduta apresenta no contexto social, não-natural. ${ }^{92}$ Dai a relevância da tcoria da imputação objetiva: "Esta interpretación de la conducta en el contexto social, junto a sus consecuencias causales o incluso a las causales anticipadas, se lleva a cabo, en la dogmática moderna, bajo el nombre de "imputación objetiva"" 93

Há três explicações possiveis para o curso danoso: conduta incorreta de terceiro, conduta incorreta da própria vítima ou infortúnio. Todas elas podem, inclusive concomitantemente, dar causa ao dano. Por isso, é impróprio se pautar a imputação somente na relação de causalidade, sendo também necessária a análise da significação social da conduta, depréendida pelas regras de linguagem que só a imputação objetiva é capaz de fornecer.

A imputação objetiva apresenta como hipótese-base a informação de que a conduta delitiva não pode ser tida analisando-se unicamente o comportamento do individuo, mas interpretando-o no seio social. Esta hipótese-base desdobra-se em três proposições:

a) Igualdade entre as pessoas. Ante a liberdade de ação, qualquer pessoa pode pretender o mesmo que pretendem as outras. Isso fundamenta o risco permitido e também a conduta criminosa, que significa um incremento do risco acima do permitido;

b) Responsabilidade das pessoas. As pessoas são responsáveis. O mundo em que se dá o comportamento é um mundo responsável, devendo-se confiar em sua correta configuração (principio da confiança). Se o destinatário da confiança for a própria vítima, então fala-se em um atuar a próprio risco;

c) A comunidade com outro é sempre uma comunidade limitada. A punição só pode ser estendida a outro quando a sociedade entender que a sua conduta também não é correta. Daí o principio da proibição de regresso.

Para Jakobs, a imputação objetiva requer a análisc da conduta segundo a ocorrência do incremento do risco acima do socialmente permitido, do principio da

\footnotetext{
92 "Al igual que la garantia de la vigencia de la norma, asi también su perturbación no ocurre mediante la naturalcza, sino mediante el sentido. Por ello, los sucesos naturales. como los cursos causales o los hechos psiquicos, no sun per se integrantes de la conducta delictiva, sino en sú carácter de portadores de un simbolo." Id., ibid., p. 55.

93 Id., ibid.. p. $41-42$.
} 
confiança, ${ }^{94}$ do princípio da proibição de regresso e do âmbito de competência da vítima. A teoria do incremento do risco e o princípio da proibição de regresso já são conhecidos. O âmbito de competência da vítima, por sua vez, será abordado adiante, quando do estudo sobre o consentimento do ofendido (ponto 4.3). Quanto ao princípio da confiança, ele ocorre quando uma ou mais pessoas são garantes da não ocorrência do resultado lesivo e suas ações dependem da conduta de outras pessoas. () princípio coloca que os atores sociais não devem desconfiar da conduta de seus colaboradores, sob pena de não conseguirem realizar as suas próprias.

A confiança é a base das relações sociais: as pessoas devem agir mediante o pressuposto de que cada um realizará devidamente sua conduta. Aquele que é garante da não-ocorrência do resultado lesivo e coloca em risco o bem jurídico penalmente protegido, produzindo o resultado, será responsabilizado, pois defraudou a relação de confiança. Como exemplo tem-se a operação médica em que o anestesista, contrariando as normas técnicas, ministra uma dose excessiva da substância anestésica, acabando por provocar a morte do paciente. Neste caso, o responsável pela morte será o anestesista. e não os médicos cirurgiões, pois o incremento do risco partiu do primeiro, e não cabia aos últimos fiscalizar a dosc da subsiância anestésica ministrada.

Para o autor, o princípio da confiança apresenta três limites, quais sejam: a) a incapacidade da pessoa para ser responsável pela conduta; b) a investidura de um dos agentes na função de corrigir as falhas do outro; e c) a realização, por um dos agentes, da conduta que frustra as expectativas de confiança.

$\mathrm{Na}$ imputação objetiva há um fenômeno idêntico ao da posição de garante nos delitos de omissão, vez que em ambos a competência é estabelecida por organização. Os delitos de omissão não podem ser determinados pelo nexo causal, vez que neles o resultado lesivo ocorre mesmo sem a atuação do agente. Tais casos são resolvidos de forma normativa, através da determinação da posição de garante, que vincula determinada pessoa à prevenção do resultado. Inicialmente restrita aos delitos omissivos, esta relação passou também a ser utilizada. através da imputação objetiva, nos delitos de comissão, pois nem sempre os resultados por eles produzidos conseguem ser imputados ao agente exclusivamente pela relação de causalidade.

A partir do Iluminismo, a ação humana passou a ser entendida como um sucesso da natureza, não podendo ser valorada como boa ou má. A evitabilidade (dolo de tipo) e a imprudência do tipo se converteram em pressupostos óbvios de imputação para

\footnotetext{
94 O autor discomc sobri o principio da confiança em sua obra Estudios de dercho penal, Madrid. Civitas. 1997. p. $218-220$.
} 
um mundo desmistificado. Assim surgiu a imputação de base unicamente subjetiva. que levava em consideração somente a intenção do individuo.

Fsta passividade e esta ausência de valoração frente aos mecanismos da natureza geraram a necessidade de valorar a conduta humana de acordo com a linguagem social. inserindo a parte (conduta individual) no todo (socicdade). Uma imputação subjetiva cuida apenas da obediência da norma pelo indivíduo. Já a imputação objetiva cuida da vigência do status quo social através da repressão das condutas socialmente desestruturantes, o que é feito pela imposição de pına quando da desobediência às normas penais.

As condutas subjetivamente psíquicas só adquirem um significado quando separadas da consciência individual e entendidas como parte de um processo comunicativo, pois alguém só é pessoa enquanto inserida em sociedade. A pessoa deve sempre respeitar as demais, sendo este respeito o pressuposto mesmo de sua individualidade, razão pela qual é assegurado pelas normas jurídicas, principalmente por aquelas de natureza penal. O desrespeito a uma norma penal significa o desrespeito da sociedade e da própria pessoa enquanto tal.

O autor afirma que a atuação de um incapaz que produz um resultado lesivo não-participa da produção de um sentido comum por não frustrar a expectativa normativa, apresentando-se como um mero processo natural, carente de sentido. Contudo, ć melhor discutir a capacidade na esfera da culpabilidade, sob pena de se transferir a análise de todos os elementos do crime ao momento da imputação. sobrecarregando-a e causando um retrocesso na doutrina penal. Outra má conseqüência de considerar-se a conduta do incapaz carente de significação é a aceitação de que os incapazes são apenas natureza, não pessoas que praticam ações.

Para Jakobs. a culpabilidade não representa uma subjetivização, mas antes uma personalização especial. A conduta será mais ou menos reprovável dependendo das circunstâncias. Ex.: O furto de objetos de uma pessoa desmaiada é mais reprovável do que aquele comctido contra uma pessoa descuidada, que larga seus objetos para olhar as vitrines de uma loja. O que fundamenta a desigualdade da punição não é a subjetividade do autor, mas antes a necessidade social de satisfazer a legítima exigência da vítima desamparada, como no primeiro caso, ou a renúncia de sua autoproteção, como no segundo caso. Tudo depende da legitimação da conduta do agente perante a sociedade.

A teoria normativo-funcional de Jakobs, ao entender que a ação criminosa apresenta um significado apenas quando imersa em determinado contexto social, foi extremamente importante à teoria da imputação objetiva, pois introduziu o elemento da significação social da conduta como critério de imputação: 
$O$ ato punivel, nessa teoria, tem um significado de exteriorização comunicativa e que expressa um sentido determinado. Não se trata de uma ação exclusiva no mundo material, no sentido causalista. muito menos a pretensão finalista de causalidade antecipada na consciência. A conduta tem um significado somente no contexto social, o que determina a análisc não só do comportamento do agente, mas também da vitima e de terceiras pessoas, num conjunto global, que se denomina, na atualidade, de imputação objetiva.

\section{Consentimento do ofendido e imputação objetiva}

\subsection{A teoria de Roxin}

Para Roxin, ${ }^{96}$ ferrenho defensor da teoria monista, o consentimento exclui sempre o tipo penal. pois é fundamentado na teoria liberal do bem jurídico ligado ao indivíduo, por ele mesmo desenvolvida. Segundo ela, a principal função dos bens juridicos é o livre desenvolvimento do indivíduo. de forma que sua livre disposição pelo portador não implica a lesão destes bens. mas antes a sua expressão. Entendimento contrário confunde o objeto da ação com o próprio bem jurídico. Se uma pessoa pede a outra que destrua sua bicicleta, a lesão scrá o objeto da conduta, mas não se confunde com o bem jurídico, que é exatamente a sua capacidade de disposição da bicicleta pelo seu dono.

O consentimento como exclusão do tipo funda-se na liberdade de ação constitucionalmente garantida, ${ }^{97}$ objeto de proteção de todos os tipos penais:

(...) la libertad de movimiento presupone la voluntad (al menos latente) de quien quiere moverse; por si mesmo el cuerpo es objeto de protección no como conglomerado de carne y huesos, sino sólo en conjunción con el espiritu que en il domina. Acertadamente formula Rudolphi: 'Bien juridico y poder de disposición sobre el bien juridico forman no solo una unidad, sino que objeto de disposición y facultad de disposición son. en sua relación mutua, de por si, el bien juridico protegido en el tipo ${ }^{98}$

\footnotetext{
95 CAMARGO, A. L. Chaves. Impulação Objetiva cil., p. 86 (grifos do texto).

96 ROXIN, C. Derecho penal cit., p. $511-532$.

97 Na Constituição Federal brasileira a liberdade de ação encontra-se garantida implicitamente em seu art. $1^{\circ}$, inciso Ill, que assegura a dignidade da pessoa humana. e explicitamente em seu art. $5^{\circ}$. caput.

98 ROXIN, C. Derecho penal cit., p. 518, apud H.-J. RUDOLPHI, ZSTW 86 (1974), 87.
} 
O consentimento deve sempre excluir o tipo, pois o bem penal protegido em todos os tipos é a liberdade individual, e não os bens jurídicos em si mesmos considerados. Como o consentimento gera a exclusão do tipo penal, não há desvalor do resultado c, conseqüentemente, também não há desvalor da ação.

Roxin admite que em algumas situações, mesmo quando consentido, o dano pode colidir com o bem-estar do portador do bem jurídico. Nestes casos, a eficácia do consentimento é excluida pelos vícios da vontade ou por seus próprios limites, tal como o da contrariedade aos bons costumes. Entretanto, este limite é por demais indefinido e contraditório, em muito cerceando a liberdade individual. Além disso, deve-se ter em vista os casos em que o consentimento colide com o bem-estar social, e não apenas com o bemestar individual. Não se pode esquecer que o indivíduo é a expressão mesma da sociedade da qual pertence, sociedade esta cuja ordem precisa ser mantida.

Para o autor, o consentimento não pode ser tido como excludente da antijuridicidade, pois representaria um corpo estranho às causas de justificação. Todas as causas de justificação se fundamentam nos princípios da Ponderação de Interesses e da Necessidade. Ao contrário, o consentimento não compartilha destes princípios, pois nele não há um conflito de interesses entre consenciente e o consentido, tampouco a necessidade do feito.

Roxin coloca que Noll tentou estabelecer um conflito para o consentimento ao afirmar que nele há um confronto entre a liberdade individual e o interesse da sociedade na conservação de bens jurídicos. Afirma também que tal conflito não é decisivo, vez que não se materializa em uma situação concreta, apresentando-se apenas como uma restrição geral do legislador à faculdade de disposição de bens pelo indivíduo.

Tem-se, para nós, que o argumento apresenta-se equivocado. $O$ consentimento geralmente envolve um conflito entre o interesse individual, fundamentado na liberdade de disposição do indivíduo, e o interesse social, que tem por base a manutenção de bens jurídicos relevantes. Ao contrário do que afirma Roxin, este conflito materializa-se na situação concreta, tanto que não é possível fixar de antemão quais bens são renunciáveis e quais são irrenunciáveis pelo indivíduo, tudo dependendo de fatores como a relevância social do bem, a gravidade da lesão, a finalidade do consentimento, o estado de conservação do bem, dentre outros. De acordo com a teoria da imputação objetiva, não é o legislador. mas a sociedade, através de seu agir comunicativo, quem deve fixar os casos de eficácia do consentimento, indicando quais interesses devem ser protegidos.

O autor apresenta mais um argumento para a fundamentação de seu paradigma monista: a impossibilidade de uma clara delimitação dos casos de acurdo. Por 
exemplo: no crime de cárcere privado (art. 148 do C.P) pode-se dizer que a prisão mediante o consentimento da vítima está apenas justificada. pois o consentimento não elimina a sua prisãu. Por outro lado, o consentimento também pode configurar um caso de acordo, pois o tipo prescreve "privar alguém de sua liberdade", o que não ocorre no caso em questão. Assim, a teoria monista seria melhor que a dualista, pois. ao contrário da segunda, ela não separa o bem juridico da liberdade de disposição de seu portador. renunciando a distinção entre acordo e consentimento.

Também este argumento é equivocado. O tipo de seqüestro e cárcere privado prevê a conduta de "privar alguém de sua libcrdade, mediante seqüestro ou cárcere privado" O núcleo do tipo é a privação da liberdade lato senso, e não a prisão, que é a privação da liberdade ispecífica de locomoção. Se determinada pessoa deseja permanecer trancada na casa de outrem o tipo não se configura, pois sua liburdade não foi extinta. mas antes manifestada. Trata-se, portanto, de um evidente caso de acordo.

Não há óbice à classificação dualista consentimento c acordo. Tudo depende da estrutura do tipo penal: se o dissenso for elemento integrante do tipo, então haverá acordo, e se o dissenso não for seu elemento integrante, então haverá consentimento. O problema desta classificação não é a caracterização dos institutos (consıntimento e acordo), mas antes a sua rigidez. É necessário que ela seja flexibilizada, de modo que o consentimento que exclui o tipo (acordo) possa ser estendido a tipos que não prevêem o dissenso como seu elemento integrante, mas que protejam, sobretudo, a capacidade de disposição de bens pelo indivíduo.

Aqui há certa proximidade com a teoria de Roxin, ao defender-se que alguns tipos protegem a capacidade de disposição de bens pelo indivíduo, e não os bens em si considerados (bem em espécie). Tais tipos não necessariamente precisam conter o dissenso como elemento integrante. Por exemplo, no delito de perigo de contágio venéreo (art. 130 do $\mathrm{CP}$ ), se a pessoa pratica relações sexuais sem o uso de preservativo, consentindo sobre um possível contágio de moléstia, então o resultado lusivo (transmissão da doença) não poderá ser imputado ao consentido, pois neste caso o tipo protege não a periclitação da vida e da saúde. mas antes a sua liberdade de disposição, motivo pelo qual a conduta é atípica.

A tutela da liberdade de disposição de bens pelo indivíduo é limitada, não estando presente em todos os tipos penais. Há também tipos que tutelam os bens em espécie (bens em si considerados), em virtude da relevância sucial que eles apresentam. como os tipos que tutelam a vida (homicídio, infanticidio, dentre outros). Nestes casos, o consentimento pode assumir força justificante, não sendo hábil a excluir a tipicidade. Dai a incongruência com a teoria de Roxin, ao defender que todos os tipos protegem a 
liberdade de disposição do indivíduo sem mais. É a sociedade, através de seu agir comunicativo, quem determina quais tipos protegem a liberdade de disposição pelo indivíduo e quais protegem os bens em espécie. Estes valores devem ser depreendidos e aplicados pelo juiz no caso concreto.

O autor afirma que o consentimento não pode recair sobre bens cuja lesão se dirija à sociedade, pois eles não estão à disposição daquele que consente, não podendo ser objeto do consentimento. Por exemplo, o consentimento não pode recair sobre os crimes de falso testemunho (art. 342 do CP), de falsidade documental (arts. 296 a 305 do C'P) e até mesmo de adultério (art. 240 do CP).

Para Roxin, há duas teorias que tratam sobre a eficácia do consentimento nos tipos que protegem interesses particulares e sociais: a teoria da alternatividade e a teoria da cumulatividade. A primcira coloca que se deve escolher qual dos interesses (particular ou social) está sendo protegido no caso em questão. Protegido o interesse particular, então o consentimento é eficaz. Já a segunda defende que ambos os interesses são tutelados de forma simultânea, razão pela qual o consentimento não é efícaz.

Ele assevera que o consentimento sobre o bem jurídico individual vida humana é totalmente ineficaz, não podendo extinguir a punibilidade do feito, mas apenas atenuá-la. Primeiro porque "un consentimiento precipitado o influido por altcraciones psíquicas desconocidas puede causar daños irreparables, de modo que la víctima debe ser protegida también de sí misma" Segundo porque "la creación de tabúes respecto de cualquier muerte de un tercero no justificada por legítima defensa consolida el respecto por la vida humana y sin duda alguna contribuye con ello a la protección de este supremo bien jurídico". 99 Tem-se, para nós, que não se pode ser tão inflexível sobre a impossibilidade de renúncia da vida pelo consenciente, pois há casos, como na eutanásia, cm que a sua disposição é não só possivel, mas também necessária.

Os argumentos apresentados por Roxin são facilmente rebatidos. Quanto ao primeiro, diga-se que a certeza sobre a vontade do consenciente, bem como a sua plena capacidade de entendimento e discernimento, são requisitos de validade em relação a todos os bens jurídicos, e não apenas à vida. Se comprovado que no caso concreto o consenciente outorgou o consentimento de forma precipitada ou sob influência de alguma interação psiquica incomum, então ele não será válido, não provocando efeitos na esfera penal.

Quanto ao segundo, ressalte-se que, tal como a legítima defesa, o consentimento também sè apresenta como causa supralegal de justificação. Já existe um tabu sobre a morte provocada por terceiro, excluindo-se aquelas provocadas por uma

99 Id.. ibid., p. 529. 
causa de justificação, dentru elas o consentimento da vítima. Aliás, nos casos de eutanásia. o consenso social prima pela morte da vitima, e isso não quebra o tabu da morte provocada por tercciro.

Um dos principais limites propostos pelo autor à eficácia do consentimento é a contrariedade aos bons costumes. Uma conduta só poderá sur contrária aos bons costumes quando: i) contrariar princípios íticos cuja lesão cause dano social; e ii) ser reprovada pelo ordenamento juridico:

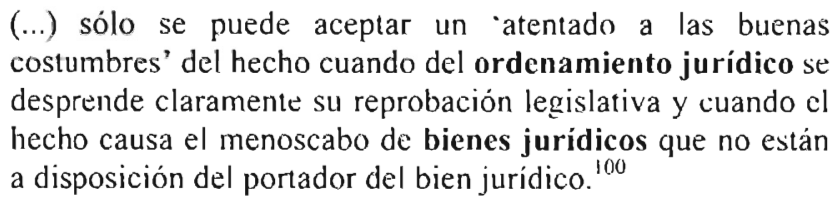

Não há como estabelecer um limite de natureza moral para a eficácia do consentimento pois, como assevera o próprio autor. ${ }^{101}$ o Direito Penal deve sempre estar fundamentado em bases constitucionais. Por outro lado, estabelecê-lo em base exclusivamente normativa é igualmente impróprio, pois não considera a análise das circunstâncias do fato. Aí reside a indefinição e o equívoco do limite da contrariedade aos bons costumes, que apresenta natureza moral, mas é determinado conforme o ordenamento juridico.

Na verdade, o paradigma monista em muito prejudica o estabelecimento de limites ao consentimento. Isso porque, ao propor que todos os tipos penais tutelam a autonomia individual, fazendo com que o consentimento recaia unicamente na esfera típica, ela não abre espaço para a conflitualidade latente que existe entre os interesses individuais e sociais, transformando o Direito Penal em um mecanismo de proteção exclusivamente individual.

É certo que o autor procurou diminuir este individualismo extremo colocando a afronta aos bons costumes como limite à eficácia do consentimento, mas não logrou êxito, ante a falta de fundamentação, em sua teoria, da importância dos interesses sociais. Frise-se ainda a indefinição e o equivoco do limitc da contrariedade aos bons costumes, conforme acima discuido.

Como defensor do paradigma monista, o maior contributo de Roxin foi a idéia de que o tipo penal pode proteger a capacidade de disposição de bens pelo seu portador, como expressão mesma de sua liberdade individual, mesmo apresentando

100 Id., ibid., p. 530 (grifos do texto).

101 Id., ibid., p. 530. "Adcmás, el Derecho penal es, por motivos de proporcionalidad, sólo el medio más extremo de reacción estatal y por ello no dehe trazar una frontera en cualquier caso en que no sca suficiente la garantia constilucional" 
grandes dificuldades ao tentar estabelecer os limites do consentimento ante a esfera social, pois o paradigma monista não permite o conflito de interesses.

\subsection{A teoria de Jescheck}

Diversamente de Roxin, Jescheck ${ }^{102}$ é defensor do paradigma dualista, diferenciando o acordo do consentimento. Para ele, há alguns tipos que prevêcm a aquiescência do individuo como elemento estrutural, enquanto outros pressupõem a sua não aquiescência. Nestes últimos tem lugar o acordo, que exclui a tipicidade da conduta e ocorre nos casos de furto, rapto, invasão de domicílio, dentre outros.

Existem ainda tipos em que a lesão do bem agride toda a sociedade, motivo pelo qual sua disposição pelo indivíduo não constitui um processo social normal. Neles, a aquiescência do ofendido dá lugar ao consentimento, que atua somente como causa de justificação, pois a liberdade de disposição do indivíduo encontra-se limitada. $O$ consentimento dá-se. por exemplo, no caso daquele que se deixa trancar para realizar uma experiência científica, sendo impedido de ter contato com o mundo exterior.

Alguns defensores da clássica divisão acordo-consentimento entendem que o acordo aprescnta natureza puramente fática, sendo eficaz. mesmo se prestado mediante os vícios da vontade, exceto sï, nos lipos que prevêem violência ou grave ameaça, prestado mediante coação. Também defendem que no acordo o ofendido não necessita manifestar sua aquiescência, nem tampouco conhecer o valor do bem jurídico agredido, e o agente não necessita ter conhecimento da manifestação do ofendido. Jescheck discorda de tal posicionamento, colocando que nem sempre o acordo apresenta natureza fática. dependendo ela do sentido e da finalidade do tipo.

No delito de violação de domicílio (art. 150 do CP), qualquer vício quanto à manifestação da vontade da vítima pode gerar a nulidade do acordo. Já no delito de estupro (art. 157 do CP), somente a aquiescência do ofendido mediante coação gera a incficácia do acordo, pois o tipo prevê a violência ou a grave ameaça como seu elemento estruturante. Isso significa que uma relação sexual na qual um dos parceiros atue mediante erro ou fraude não caracteriza o tipo de estupro, não sendo tais vícios hábeis a provocar sua nulidade.

A doutrina muito discute sobre a função do consentimento ${ }^{103}$ na teoria do delito, questionando se ele assume a posição de excludente do tipo ou da antijuridicidade. $\mathrm{O}$ autor defende que o correto é entendê-lo como uma causa de justificação. Isso porque

102 JESCHECK, H.-H. Tratado de derecho penal cit., p. 510-535.

${ }^{103}$ Do início ao fim do subitem 4.2, com exceção de seu último parágrafo, o vocábulo consentimento ¿ entendido em sua forma estrita, como aquele que se contrapòe ao acordo. 
bens como a vida, a integridade física, a honra, o patrimônio, e a esfera íntima são relevantes a toda sociedade, não podendo, nestes casos, a aquiescência do ofendido ser aceita sem mais. ${ }^{104}$

Tım-se para nós que a sociedade, através de seu agir comunicativo, entende que bens como a honra e o patrimônio são relevantes apenas ao indivíduo. Nestes casos, a manifestação da aquiescência é fator de exclusão da própria tipicidade, sendo sempre eficar, pois recai sobre os tipos que tutelam a liberdade de disposição de bens pelo indivíduo.

Já bens como a integridade fisica, a esfera íntima, e outros apresentam relevância ora social, nos tipos que asseguram os bens em espécie em si considerados, e ora individual, nos tipos que asseguram a liberdade de disposição de bens pelo indivíduo. A aquiescência sobre estes bens pode tanto figurar uma causa de justificação como uma causa de atipicidade. Isso the atribui maior mobilidade, permitindo à sociedade escolher quais bens são a ela relevantes e quais são relevantes ao indivíduo. Mesmo quando outorgada sobre um bem social, nos tipos que asseguram os bens em espécie (bens em si considerados), a aquiescência pode ser eficaz como causa de justificação, se na ponderação de interesses o interesse individual prevalecer sobre o social.

Para Jescheck, o consentimento será eficaz se levar em conta não apenas o interesse do indivíduo, mas também o da sociedade da qual fa7 parte, pois não é razoável que se sacrifique o interesse de uma sociedade inteira para que se realize determinado interesse individual. O consentimento será eficaz. somente em relação aos bens individuais e apenas se aquele que consente for o titular do bem jurídico protegido. É por isso que ele é ineficaz na insligação ao suicídio, bem como nas demais formas de autocolocação em risco da vida. Quanto às lesões corporais, será eficaz somente se outorgado conforme os bons costumes. ${ }^{105}$

Diversamente, entende-se que o consentimento pode ser eficaz mesmo se outorgado sobre um bem social. como a vida. Dada sua relevância social, o tipo penal de homicidio (art. 121 do CP) tutela não a capacidade de disposição da vida por seu portador, mas a vida em si considerada. Neste caso, o consentimento pode ser eficaz como causa de justificação, desde que fatores como a gravidade da lesão, o estado em que se encontrava o bem, a finalidade do consentimento e outros autorizem a lesão.

$O$ autor afirma que a única exceção à ineficácia do consentimento outorgado sobre bens sociais é aquele manifestado pelos órgãos encarregados da proteção da Constituição sobre ações típicas que coloquem em risco o Direito Penal político, pois

104 Id., ibid., p. 513-514.

105 Id. Ibid.. p. 516-519. 
neste caso não se trata de particulares, mas de autoridades estatais com poderes representativos. $^{100}$ Esta afirmação também é equivocada. $O$ consentimento não pode ser outorgado por representantes, quanto mais por órgãos ou agentes públicos, dado o seu caráter personalíssimo.

Outro requisito proposto pelo autor para a validade do consentimento é a sua não contrariedade aos bons costumes. Ele mesmo reconhece que tal limite deve ser imposto somente em relação às grandes lesões, sob pena de promover-se uma moralização extrema do Direito Penal. Assinale-se aqui a mesma critica tecida à contrariedade aos buns costumes proposta por Roxin como limite ao consentimento.

Seguidor do paradigma dualista, Jescheck diferenciou-se por sua extrema rigidez quanto à efícácia do consentimento ${ }^{107}$ em relação aos bens de natureza híbrida e social, limitando demasiadamente o seu âmbito de atuação, não permitindo a mobilidade de valores que a teoria da imputação objetiva é capaz de atribuir aos tipos penais.

\subsection{A teoria de Jakobs}

Jakobs $^{108}$ defende que, ao longo dos anos, tem-se observado uma modificação quanto à função do Estado, que passou de intervencionista a mero gestor, causando um estreitamento da vida pública e um alargamento da iniciativa privada. Isso fez com que condutas como a autolesão, a heterolesão mediante o consentimento da vítima e a sua participação na autocolocação em risco não constituam injustos, pois nestes casos o agente não prejudica o âmbito de organização da vítima, mas ao contrário o estimula, provocando apenas uma lesão aparente ao bem jurídico pessoal.

O âmbito de competência da vítima constitui um dos elementos de análise da teoria da imputação objetiva. ${ }^{109}$ Seu principal fundamento reside não na sua vontade interna, mas no alargamento do dever de autoproteção que a manifestação desta vontade ocasiona. O caso mais discutido da competência da vítima por uma atuação precedente é o do consentimento, mas antes é necessário que se discorra sobre alguns outros pontos - tais como a autolesão e da heterolesão - pois, para o autor, o consuntimento deve sempre ser analisado em conjunto com eles.

Há um tabu scgundo o qual quem atua em último lugar é quem irremediavelmente toma a decisão definitiva sobre a realização do feito. Jakobs sustenta

\footnotetext{
106 Id., ibid., p. 520.

107 Aqui, o vucábulo "consentimento" é entendido em seu sentido lato, abrangendo tanto o consentimento quanto o acordo.

108 JAKOBS, G. Estudios de derecho penal. Madrid: Civitas, 1997. p. 395-412.

109 Contorme mencionado no ponto 3.5.3. p. 51.
} 
que tal afirmação não é correta porque, nos delitos a pedido da vítima, quem executa a ação lesiva é um terceiro, mas quem apresenta o domínio do fato é a própria vítima, pois ela deve manter sua posição até o final para que a conduta ocorra

Assim, o atuur ${ }^{\text {lJ }}$ por último não deve ser entendido em sua forma puramente naturalista, mas no sentido de que aquele que atua em último lugar é o garante da não ocorrência do resultado, ou seja, é o responsável para que o resultado não se verifique. Disso decorre que o resultado produzido pelo agente só poderá ser a ele imputado se ele for o garante de sua não ocorrência. Ex. o médico é responsável pela morte de determinado paciente se desligar o aparelho através do qual o último está respirando, pois neste caso o médico é garante da vida do enfermo. Por sua vez, se a faxineira do hospital desligar o aparelho, ela não pode ser imputada, vez que não é garante da vida do paciente.

A autolesão não pode ser definida como a lesão que é determinada e sofrida pela mesma pessoa, pois se deve ter em conta os casos de autolesão praticada por terceiro a pedido da vítima. Alguns autores rechaçam a idéia de autolesão a pedido da vítima, pois colocam que, se permitida, ela será a regra, não a exceção. Jakobs refuta esta hipótese. Para ele, a vítima só poderá se autolesionar quando a sua conduta for devidamente justificada, como na eutanásia, por exemplo. ${ }^{111}$

A assunção da conduta perigosa pela vitima pode ocorrer mesmo sem um dado subjetivo, ou seja, sım a manifestação de sua vontade, pela simples atuação a próprio risco. A atuação a próprio risco ocorre quando a vítima é incitada por terceiro a realizar uma conduta danosa a determinado bem jurídico dela sem uma forte razão que fundamente esta conduta, como por exemplo, o do amigo que empresta seu automóvel para que outro (devidamente habilitado) realize um "racha". acabando por se matar em um acidente. Neste caso, o amigo que emprestou o carro não pode ser imputado pela morte do outro, pois o agente não apresenta a obrigação de proteger os bens jurídicos da vitima de forma mais cuidadosa que ela mesma.

O autor afirma que toda pessoa apresenta uma obrigação de autoproteção, obrigação esta que possui natureza institucional, independe da realização anterior de organização, e por isso está presente não apenas quando a pessoa incrementa seu próprio risco, mas também quando ele é incrementado por terceiros. A pessoa que sem querer toma um veneno ministrado dolosamente por outra, tem a obrigação de se dirigir até um hospital, tomar um antidoto ou fazer o que estiver a seu alcance para que o

110 O vocábulo ahuar compreende tanto a ação quanto a omissão do agente.

111 "En una suciedad que ya no ve ningún sentido en el dolor, y que considera que siempre tiene sentido evitarlo, no puede definirse al homicidio de modo gencral como medio inadecuado y, en cambio, considerar la muerte "natural' como una salvación". Id., ibid., p. 398. 
envenenamento cesse. Se assim não procede, a responsabilidade do agente pode ser diminuída ou até mesmo extinta. A obrigação de autoproteção é determinada pelas regras da competência de organização da vítima.

Quando a vítima è meramente um instrumento mediato do agente, fala-se em heterolesão, pois ele atua em último lugar, sendo competente para evitar o resultado, e. conseqüentemente, responsável pela sua ocorrência. Para que a atuação mediata ocorra é necessário que o agente crie um risco não permitido através de uma fraude ou da inconsciência da vítima. Por exemplo: em uma relação sexual sem o uso de preservativo, se $A$ desconhece que B possui AIDS, mas sabe que ele é do grupo de risco, então B não pode ser imputado pela contaminação de A. Entretanto, se B, conhecendo sobre sua doença e não participando do grupo de risco, convence A a confiar nele, então nestc caso há autoria mediata. ${ }^{12}$

Tem-se que este exemplo não é o mais acertado, pois atualmente a idéia de "grupo de risco" já foi superada e qualquer pessoa pode ser portadora do vírus HIV. Muitas delas nem sabem que o são. Ao realizar relações sexuais sem o uso de preservativo, a vítima sabe que está incrementando um risco a si mesma, e isso independentemente do fato de seu companheiro saber sobre a doença ou incitá-la a confiar nele. Todos estes casos tratam de uma autolesão através de um atuar a próprio risco, não havendo lugar para a ocorrência da heterolesão mediata.

Jakobs também fala sobre a quasejustificação, que ocorre quando, na autoria mediata, a vítima sacrifica determinados interesses para manter outros incólumes, em uma atuação com base no estado de necessidade justificante. ${ }^{113}$ Ao contrário dele, na quasejustificação, a vítima está autorizada a sacrificar bens de maior importância que o protegido, desde que isso seja racional nas circunstâncias. A quasejustificação também se diferencia do estado de necessidade exculpante, vez que não é orientada pela necessidade de manutenção do estado de conservação da vítima, mas antes porque sua autoconservação já não é a melhor solução.

Exemplo de uma quasejustificação é a pessoa que pede para ser morta por terceiro a fim de evitar as dores da tortura à qual será submetida. Neste caso, tanto aquela que pediu para ser morta como aquela que provocou a morte não pode ser responsabilizada, pois a conduta encontra-se quasejustificada.

Tal posicionamento, contudo, é equivocado. Não há necessidade de se falar em quasejustificação, pois a ponderação de interesses que ela proporciona pode ser

$11 ?$ Id., ibid., p. 404-405.

113 " $Y$ es que 'cuasijustificación' significa lo seguiente: el sujeito que se autolesiona tienc una buena razón para hacerlo; al menos, la purturbación social devienc soportable gracias a esa razón. Si eso es así, es imposible fundamentar que la victima deba ejecutar el hecho de propia mano." Id., ibid.. p. 408. 
realizada em sede do consentimento-justificação, sendo o consentimınto eficaz. somente se o interesse da vitima for maior que o interesse da sociedade. Frize-se aqui o interesse, e não necessariamente o bem juridico, pois o bem individual pode ser menor quc o social c mesmo assim o consentimento continuar sendo eficaz se, em seu conjunto, o interesse do individuo for maior que o da sociedade.

Jakobs também coloca que no consentimento e na autocolocação em risco a própria vítima atua de maneira imputável em sua auto-organização, desestruturando-a e impedindo que outro o desestruture. Desta forma. não há injusto, pois a organização da vítima não é desestruturada por outrem, mas antes por ela mesma.

Adepto da corrente dualista, ele diferencia o acordo do consentimento. conceituando o último "como inducción o complicidad psiquica en el hecho; en la mayoría de los casos, estará acompañado por otros comportamientos de participación" 114 É indiferente que alguém se autolesione ou consinta em sua heterolesão, pois em ambos os casos não há privação de direitos, pois o consenciente as utiliza para configurar sua existência. Neste contexto, o conscntimento é expressão mesma da auto-afirmação individual.

O consentimento pode recair apenas sobre os bens intercambiáveis, ${ }^{115}$ ou seja. disponíveis, que se modificam para o desenvolvimento da personalidade. Em relação aos bens que participam da constituição da pessoa, sendo a base deste desenvolvimento, tais como a vida e a saúde, o consentimento não apresenta eficácia, exceto se outorgado por boas razões, especialmente para evitar a ocorrência de um dano ainda maior.

Jakobs sustenta que "el consuntimiento de la lesón solo es una modalidad de fundamentación de la competencia de la víctima respecto de su lesión" 116 devendo ser analisado em conjunto com as demais modalidades, tais como a autolesão, a heterolesão, a quasejustificação c outros, para saber se é ou não eficaz.

Jakobs foi importante ao diferenciar a autolesão da heterolesão, afirmando que o consentimento é indistintamente eficaz a ambos. Também foi importante ao colocar que o consentimento pode ser eficaz mesmo em relação aos bens intercambiáveis, quando sua finalidade for a de evitar um dano ainda maior, pois desta forma pode-se melhor aliar o consentimento à flexibilidade que a tcoria da imputação objetiva lhe permite atribuir.

\footnotetext{
114 Id., ibid., p. 410.

115 Conforme denominaçào atribuída pelo próprio autor. CAMARGO, A. L. CHA VES. Imputação Objetiva cit., p. 181 .

116 Id. ibid.. p. 411 .
} 
4.4. Nova visão do consentimento à luz da teoria da imputação objetiva

A teoria da imputação objetiva é extremamente relevante ao Direito Penal. mormente ao brasileiro, por inserir a significação social da conduta do agente como um novo elemento de impulação. Tal significação é objetivamente analisada através de três requisitos. quais sejam: i) a verificação de certo nexo causal entre a conduta do agente e o resultado; ii) a criação de um risco não permitido, socialmente desaprovado; e iii) a presença da conduta no âmbito de proteção da norma penal. Se a conduta não preencher estes três requisitos não há imputação, mısmo que verificada a relação causal entre ela e o resultado.

A relação causal, traduzida pcla fórmula da conditio sine qua nom, e utilizada desde os primórdios do Direito Penal como único instrumento de atribuição do resultado lesivo à determinada pessoa, passa a ser necessária, mas não suficiente, à imputação, ante problemas como o regresso ao infinito, os cursos causais hipotéticos ou salvadores, os delitos por omissão, dentre outros. Daí a necessidade da descoberta do significado social da conduta para que o resultado por ela produzido possa ser atribuído à pessoa, imputando-a como agente do resultado.

Por proporcionar uma análise menos naturalista, fundamentada no raciocínio lógico-formal, e mais social, fundada no raciocínio argumentativo, a teoria da imputação objetiva é bastante eficaz. como resposta aos problemas da criminalidade moderna, marcada pela lesão a bens e interesses difusos, na qual atuam não agentes isolados, mas organizados, em que um comanda os demais. Livre da relação causal como único fator de imputação, é possivel que se impute não apenas aquele que executa a ação com suas próprias mãos, dando causa ao resultado, mas também aquele que articula o grupo de agentes e atribui ordens. pois todos aumentam o risco social acima daquele permitido, gerando a conduta lesiva.

Mas não só: a teoria da imputação objetiva também é importante pois considera que o incremento do risco pela própria vítima pode gerar a diminuição ou até mesmo a exclusão da responsabilidade penal do agente. Todas as pessoas apresentam um dever de autoproteção. Se ele não é cumprido, não cabe ao Estado evitar o resultado lesivo, exceto se causar males à sociedade.

Assim ocorre no consentimento, em que a vítima permite a ingerência de outrem sobre bens juridicamente relevantes: dependendo da natureza do bem, esta ingerência pode ser até mesmo alípica, excluindo por completo a responsabilidade penal do agente. Mesmo em se tratando de uma ação típica, dependendo da gravidade da lesão e da finalidade do consentimento, a antijuridicidade da conduta pode ser diminuída ou excluída, refletindo na responsabilidade penal do agente. 
A imputação objetiva ainda é relevante pois permite que não o legislador, mas a sociedade, através de seu agir comunicativo, cleja quais tipos de bens o Dircito Penal deve tutelar. Estes bens, depois de escolhidos pela sociedade, devem ser codificados nos respectivos tipos penais, mas nada impede que, com o progressivo desenvolvimento social, eles sejam esquecidos ou substituídos por outros, sem que necessariamente sc alterem os tipos penais então existentes.

A sociedade brasileira passou, ao longo do século $\mathrm{XX}$, por uma série de transformações. elegendo determinados bens jurídicos como penalmente relevantes e excluindo outros da orla de proteção penal. Entretanto, o Código Penal brasileiro data de 1940, e muitos dos seus tipos não acompanharam o desenvolvimento que a sociedade presenciou até nossos dias. Fxemplos são os tipos de sedução (art. 217 do $C P$ ), de corrupção de menores (art. 218 do CP), de casa de prostituição (art. 229 do CP), de adultério (art. 240 do CP), e de inúmeros outros. As condutas descritas nestes tipos geram um risco socialmente tolerável e até mesmo comum às relações sociais, motivo pelo qual não são sequer típicas.

Outros tipos foram mantidos no sistema penal, mas os bens por eles protegidos foram substituídos. Isso ocorre nos tipos de lesão corporal leve (art. 129, caput, do $\mathrm{CP}$ ), de perigo de contágio venéreo (art. 130 do CP), de perigo de contágio de moléstia grave (art. 131 do CP), de omissão de socorro (art. 135 do CP), de dano (art. 163 do CP) e de vários outros, pois eles não mais tutelam a integridade física, a periclitação da vida e da saúde, o patrimônio e outros, mas a liberdade de disposição destes bens pelo indivíduo.

Este fenômeno ocorreu devido à transformação dos valores que a sociedade brasileira sofreu, transformação esta refletida no próprio Estado. que passou de interventor a mero gestor do âmbito privado. Ao longo dos anos, o âmbito social foi perdendo espaço para o âmbito privado, sendo uma das principais garantias que se encontra em voga a dignidade da pessoa humana, presente no art. $1^{\circ}$, inciso II, de nossa Constituição Federal e fundamento mesmo do Estado Democrático de Direito. Tendo-se em vista que a dignidade humana é a autodeterminação da pessoa segundo sua vontade, então a liberdade de autodeterminação deve encontrar cada vez mais espaço no âmbito do Direito Penal, devendo ser protegida pelos seus respectivos tipos.

Dentre os inúmeros direitos que envolvern a autodeterminação, o principal deles í a liberdade de disposição dos hens jurídicos, pois se à pessoa é fucultada a capacidade de dispor. então todas as demais capacidades estão aí incluídas. Daí a relevância jurídico-penal do consentimento do ofendido, que se encontra como expressão latente da dignidade da pessoa humana. 
O consentimento é definido como a autorização manifesta, pelo portador de bens jurídicos de elevada importância, para que outrem realize uma ingcrência nestes bens, gerando efeitos no âmbito do Direito Penal. Esta ingerência pode ocorrer de dois tipos, quais sejam, através da afïrmação do bem penalmente protegido uu através da sua lesão por outrem. No primeiro caso fala-se em um consentimento-atipicidade, e no segundo em um consentimento-justificação.

O consentimento-atipicidade tem lugar nos tipos que tutelam a liberdade de disposição de bens juridicamente relevantes pelo indivíduo. Já o consentimuntojustificação ocorre nos tipos que não tutelam a liberdade de disposição de bens pelo indivíduo, mas os bens em espécie em si mesmos considerados. $O$ consentimuntoatipicidade não equivale ao acordo, pois o segundo ocorre apenas nos tipos em que o dissenso entre a vítima e o agente é elemento estrutural do tipo, enquanto que o primeiro pode ocorrer tanto nestes quanto naqueles em que o elemento estrutural não é o dissenso entre a vítima e o agente. Tudo depende dos valores eleitos pela sociedade, a serem protegidos nos respectivos tipos penais.

O consentimento outorgado em uma lesão corporal leve é uma forma de consentimento-atipicidade, mas não de acordo. pois o tipo não apresenta o dissenso como elemento estrutural. Trata-se de um consentimento-atipicidade, pois. ao contrário dos doutrinadores dualistas, entende-se que o tipo prolege a liberdade de disposição da integridade pelo indivíduo, e não a integridade fïsica em si considerada.

O consentimento-justificação também não equivale ao conscntimento, pois o primeiro ocorre nos tipos que protegem os bens em si considerados, ou seja, os bens em espécie, enquanto que os segundos ocorrem em todos os tipos que não apresentam o dissenso como elemento estrutural. Sendo diferentes os critérios de classificação, estes institutos não podem ser igualados.

A divisão do consentimento em um consentimento-atipicidade e num consentimentu-justificação traz a necessidade de classificação dos tipos penais em tipos que protegem os bens em espécie e tipos que protegem a liberdade de disposição de bens pelo indivíduo. Quem indica qual bem deve ser tutelado por cada tipo penal é a sociedade, através do seu agir comunicativo, ou seja, de suas relações sociais, que em seu conjunto formam um consenso, um topos comum. É o magistrado, através da análise do topos social, que depreende qual destas duas classes de bens o tipo penal está protegendo. aplicando-o ao caso concreto.

Daí a relevância da teoria da imputação objetiva. Ao permitir a análisc do agir comunicativo dos atores sociais no momento da imputação, através do significado social da conduta do agente, ela permite a interpretação do tipo penal de acordo com 0 
bem eleito pela sociedade para ser protcgido, e não de acordo com o que o legislador escolhe para ser objeto de tutela penal, sem qualquer reflexo com os valores sociais então vigentes.

A imposição de um Direito Penal exclusivamente formal, atravís da elaboração de normas com a finalidade de alterar os valores socialmente vigentes, prática tão comum ao Direito Penal brasileiro, retira a legitimidade de todo o sistema penal, pois exclui o equilíbrio entre o socialmente e o penalmente aceito e entre o socialmente e o penalmente reprovado. Nas palavras de Jakobs:

Ciertamente no se debe entender la secuencia de hecho y pena. en el sentido de que se pueda añadir un derecho penal cualquiera a una sociedad a su vez cualquiera, y de que la configuración de esta sociedad esté garantizada solo en tanto le siga una pena a todo lo que, jurídicopenalmente, signifique un quebrantamiento de la norma. No se trata de la identidad de un derecho penal que permanece fiel a si mismo, sino de la identidad de la sociedad que ha diferenciado el derecho penal como sistema parcial. Por ello, la expectativa contra cuya defraudación se reacciona tiene que ser, ya con independencia del derecho penal, una expectativa social, pues, de otro modo, sociedad y derecho penal no armonizarán. (...) En un derecho penal de esa indole, la configuración exterior, que en un derecho penal adecuado es solo simbolo en el marco de una comunicación, se convierte en la esencia: se convierte en un ordenamiento coercitivo abstracto externo (al que ya no se le corresponde una sociedad). ${ }^{117}$

Portanto, a teoria da imputação objetiva permite maior mobilidade quanto à interpretação da classe de bens que o tipo penal pretende tutelar. podendo assegurar tanto os bens em si considerados quanto a liberdade de disposição de bens pelo individuo, tudo dependendo da eleição de uma ou de outra classe de bens pela sociedade. o que é feito através de seu agir comunicativo, pela elaboração de topos.

O que se busca aqui é uma forma de paradigma dualista com elementos tipicamente monistas. Como no dualismo, o consentimento i dividido em um consentimento que retira a tipicidade da conduta (consentimento-atipicidade) e $\mathrm{cm}$ um consentimento que retira a sua justificação (consentimento-justificação). Contudo, aproxima-se dos monistas an afirmar que o consentimento-atipicidade ocorre nos tipos que tutclam a liberdade de disposição de bens pelo indivíduo, e que esta liberdade de

117 Id., Problemas capitales cit., p. 34-35. 
disposição não ocorre apenas nos lipos que apresentam o dissenso entre a vítima e o agente como elemento estrutural, mas também nos tipos que não o apresentam.

O consentimento-atipicidade não implica uma lesão ao hem tipicamente protegido, mas antes a sua afirmação, vez que o bem tutelado é a liberdade de disposição de bens pelo individuo. Isso não significa que no consentimento-atipicidade não há qualquer lesão. Há uma lesão que recai sobre um bem jurídico não tutelado penalmente.

Ex.: a sociedade, através de seu agir comunicativo, entende que o tipo de dano (art. 163 do CP) tutela não o patrimônio em si considerado, mas antes a liberdade de dispusição do patrimônio pelo seu proprietário. Se A destrói o carro de B sob o consentimento do último, neste caso há lesão ao bem jurídico patrimônio privado, mas não ao bem penalmente tutelado, pois o tipo de dano tutela justamente sua liberdade de disposição do carro pelo proprietário, e não a propriedade do carro em si.

Já o consentimento-justificação implica lesão ao bem penalmente tutelado, vez que o tipo protege os bens em espécie, ou seja, os bens em si considerados, tais como a vida, a integridade física, o patrimônio, dentre outros. Neste caso, embora a responsabilidade penal do agente também possa ser excluída, ela o será na esfera da antijuridicidade, como causa supralcgal de justificação. e não na esfera da tipicidade, como excludente do tipo penal. Enquanto no consentimento-atipicidade a exclusão da responsabilidade penal do agente é uma certeza, no consentimento-justificação ela é uma incógnita que dependerá da prevalência do interesse individual sobre o social.

O consentimento-justificação sempre envolve um conflito entre os interesses individuais e os sociais. Geralmente, quanto maior a relevância social do bem. maior o interesse da socicdade e, portanto, menor a eficácia do consentimento. Todavia, há casos nos quais mesmo em se tratando de bens jurídicos de natureza social, com grande relevância à sociedade, o interesse individual pode fazer com que o consentimentojustificação seja eficaz. Tal ocorre, por exemplo, na eutanásia, quando a manutenção dá vida causar grande sofrimento à pessoa e a seus familiares. Em casos como este, o consentimento-justificação é eficaz a ponto de excluir a responsabilidade penal do agente.

Os principais pontos de análise sobre a eficácia do consentimentojustificação são, primeiramente, a relevância social do bem e. secundariamente, a gravidade da lesão e o motivo do consentimento. Mesmo que recaia sobre um bem social, o consentimento-justificação pode ser eficaz, desde que a análise dos pontos secundários permita a eficácia. Isso ocorre pois nenhum bem é totalmente irrenunciável.

O consentimento é melhor ajustado ao Direito Penal, principalmente ao brasileiro, se analisado sob a sistemática da teoria da imputação objutiva, pois ela permite maior flexibilidade dos bens tipicamente tutelados, fazendo com que o consentimento ora 
se manifeste como consentimento-atipicidade e ora como consentimento-justificação, tudo conforme os valores socialmente eleitos e refletidos no tipo penal, aplicados ao caso em concreto pelo magistrado. Isso faz com que o consentimento tenha um âmbito de eficácia muito maior, ampliando a própria legitimidade do Direito Penal, pois permite que ele acompanhe o desenvolvimento da sociedade, captando seus valores vigentes.

\section{Conclusões}

1. O consentimento do ofendido é a autorização manifesta, pelo portador de bens jurídicos de elevada importância, para que outrem realize uma ingerência nestes bens, em efetiva consonância com o princípio da dignidade da pessoa humana, apresentando por conseqüências a auto-responsabilidade da vítima e a diminuição ou exclusão da responsabilidade penal do agente. Divide-se em consentimentoatipicidade, que é o exercício, pelo ofendido, da liberdade de disposição de bens juridicamente relevantes; e em consentimento-justificação, que é a renúncia, enquanto vontade por ele externada, à proteção penal dos bens juridicos oferecida pelo Estado. O primeiro ocorre nos tipos que tutelam a liberdade de disposição de bens pelo indivíduo e tem como conseqüência a exclusão da responsabilidade penal do agente. enquanto que o segundo ocorre nos tipos que tutelam os bens em espécie, e pode acarretar na diminuição ou na exclusão de sua responsabilidade, tudo dependendo do confronto entre o interesse individual e o social:

2. O consentimento do ofendido apresenta natureza eminentemente penal, constituindo instituto autônomo ao Direito Civil. Suus requisitos de existência são: i) o ofendido; ii) o ofensor; iii) a ingerência do ofensor a um bem juridicamente relevante; e iv) a manifestação de aquiescência, pelo ofendido, sobre esta ingerência. Com a manifestação do consentimento, a relação entre ofendido e ofensor ganha contornos especiais. passando o primeiro a ocupar a posição de sujeito ativo ou consenciente. e o segundo, a de sujeito passivo ou consentido. Os requisitos de validade do consentimento são: i) a capacidade penal do consenciente; e ii) a ausência de vícios (erro, coação e fraude) na produção e manifestação da sua vontade. Seu requisito de eficácia é a capacidade de disposição, pela pessoa, do bem objeto do consentimento. Quanto à sua capacidade de disposição, os bens podem ser classificados em: i) bens totalmente renunciáveis; e ii) bens parcialmentc renunciáveis. Já quanto à sua relevância social, eles são classificados como: i) bens individuais; ii) bens sociais; e iii) bens hibridos; 
3. O consentimento presumido é aquele que se pressupõe diante das circunstâncias. Exige os mesmos requisitos do consentimento próprio e depende de três fatores: i) ponderação de interesses do ofendido pelo ofensor; ii) decisão que o ofendido teria tomado se soubesse das circunstâncias; e iii) atuação do agente no âmbito do risco permitido. Por ser inferido pelo ofensor através de um juízo de abstração, sua eficácia está restrita aos casos de proteção da vida ou da integridade física, principalmente em relação às intervenções cirúrgicas, e mesmo nestes casos apenas quando a ação do ofensor incrementar o risco do ofendido, pois do contrário a questão será resolvida pela imputação objetiva;

4. O consentimento ex post é aquele outorgado durante ou após a execução do evento delitivo. Năo se confunde com a figura do perdão do ofendido (art. 107, inciso V, do $\mathrm{CP}$ ), nem tampouco com a do perdão judicial (art. 107. inciso [X, do CP). O consentimento ex post é sempre eficaz até o trânsito em julgado da sentença penal condenatória, pois o incremento do risco pelo consentido é absorvido pela autocolocação em risco do consenciente. Quanto à revogação, o consentimento é livremente revogável antes do início da execução do evento. Durante a execução, a revogação será eficaz apenas se a conduta puder ser interrompida, não se responsabilizando o agente pelos efeitos até então obtidos;

5. Há dois paradigmas contrapostos que tratam das conseqüências penais do consentimento: o dualista e o monista. O paradigma dualista defende que o consentimento pode excluir tanto o tipo quanto a antijuridicidade penais, dividindoo em acordo e em consentimento. O acordo ocorre nos tipos que apresentam o dissenso entre o ofendido e o ofensor como elemento estrutural, e implica a exclusão típica. Já o consentimento ocorre nos tipos que não apresentam o dissenso como elemento estrutural. e pode acarretar na exclusão da antijuridicidade, tudo dependendo se. no caso concreto. o interesse individual prevalece sobre o social. O precursor do paradigma dualista foi Geerds, acompanhado por Noll. Casas Barquero, Stratenwerth, Costa Andrade, Jescheck e Jakobs, dentre outros. Por sua vez, o paradigma monista defende que o consentimento pode excluir somente o tipo penal, vez que o objeto de proteção de todos os tipos é a liberdade de disposição de bens pelo individuo. Seus principais fundamentos são a área de tutela e o conceito de lesão. Para os monistas, o consentimento é um instituto estranho às causas de justificação, pois nele não vige o princípio da ponderação de bens. Im dos maiores defensores deste paradigma foi Roxin, em companhia de Schimidhäuser, Maurach e Zipf e outros; 
6. O paradigma dualista é mais adequado à teoria do consentimento tanto por razões politico-criminais yuanto por razões dugmáticas. Ao invés de se falar em acordo e em consentimento, como querem us dualistas, melhor falar-se em um consentimento-atipicidade. e em um consentimento-antijuridicidade. Esta nova divisão considera não o dissunso entru ofendido c ofensor como elemento integrante do tipo, mas o tipo de bem por cle tutelado. ou seja, se a liberdade de disposição de bens pelo individuo ou su os bens em espécie. Isso permite que a sociedade, atravis de seu agir comunicativo, eleja qual o bem protegido no tipo, fazendo com que o consentimento exclua a tipicidade ou a antijuridicidade;

7. De forma geral, a doutrina brasileira, de base positivista, limita-se a diferenciar o consentimento excludente da tipicidade daquele excludente da antijuridicidade, reservando o último estritamente aos bens totalmente disponíveis pelo sujeito consenciente. Isso retira grande parte da eficácia do consentimento como causa de justificação, pois somente alguns poucos bens, como a propriedade, a integridade moral e a liberdade individual, são entendidos como passíveis de disposição pelo indivíduo. Há inclusive alguns autores pátrios que não atribuem qualquer relevância ao consentimento, dada a natureza pública do Direito Penal e a incapacidade de o ofendido decidir sobre a ingerência, por outrem, em seus bens juridicamente relevantes;

8. As teorias causalistas propuseram as primeiras formas de imputação do resultado lesivo ao agente. A mais importante delas é a teoria da equivalência das coundiçõe’', que considera causa toda a condição sem a qual não se produz o resultado lesivo, sendo equivalentes todas as condições aptas a produzirem o resultado. Utiliza a fórmula da supressão mental, também conhecida como conditio sine qua non: se suprimindo a ação suprime-se o resultado, então a condição também é causa do evento. A teoria da equivalência das condições é utilizada pelos doutrinadores positivistas como forma exclusiva de imputação. Já a teoria da causalidade adequada considerava como causa somente aquela que, de acordo com as regras da vida e com a experiência geral, era, como condição, adequada a produzir determinado resultado lesivo, negando a causalidade das condições que antes do evento não ofereciam perigo em relação ao resultado típico. O juizo de adequação era feito a partir de um prognóstico objetivo-posterior. Fsta teoria não era simplesmente causal. mas de imputação. pois procurava primordialmente a relevância jurídica do fato:

9. A teoria du relevância, influenciada pelo positivismo jurídico, defendia que a responsabilidade não era composta apenas pcla causalidade, propondo uma análise 
valorativa do tipo penal. O nexo causal, por si só, não conduzia à responsabilidade jurídico-penal, pois não-significava a equivalência jurídica, devendo as condições serem analisadas em relação ao tipo penal para que se averiguassem quais as relevantes ao Direito Penal. A teoria da adequação social, por sua vez, desenvolvida pela escola finalista, afirma que só podem ser atribuidas ao agente as ações socialmente inadequadas, ou seja, aquelas que ultrapassam os limiles da liberdade de ação estabelecidos pela sociedade. Nenhuma destas teorias foi capaz de resolver antigos problemas de imputação, tais como os cursos causais hipotéticos ou alternativos, o regresso ao infinito, a interrupção de cursos causais salvadores e a causalidade no crime culposo, dentre outros;

10. A teoria da imputação objetiva foi proposta por Larenz, em 1927, voltada ao Direito Civil, e aplicada ao Direito Penal por Ilonig, em 1930. Na década de 70, Ruxin, a partir da teoria de Honig, deu um passo decisivo para o seu desenvolvimento ao elaborar a teoria du risco. Para ele, a imputação objetiva compreende três estágios: i) existência de um nexo cuusal entre a conduta do agente e o resultado lesivo; ii) incremento de um risco socialmente não permitido e iii) abrangência do risco no âmbito de proteção da norma penal. $\mathrm{O}$ incremento do risco constitui o elemento mais importante da teoria, e ocorre quando o agente realiza uma conduta juridicamente relevante, superando as expectativas de risco socialmente accitas em grau tão elevado que passa a ser proibida pelo sistema penal. Sua doutrina é especialmente importante à imputação objetiva, pois introduz a análise do risco como elemento suplementar à relação causal, fazendo com que a imputação ocorra de acordo com os valores sociais então vigentes:

11. Jescheck também foi bastante importante ao desenvolvimento da teoria da imputação objetiva ao apresentar o conceito social de ução, segundo a qual não se pode deduzir um sistema de Direito Penal a partir de alguns poucos princípios fundamentais, através de uma dedução lógica. É necessário que o Direito Penal apresente um suporte lógico-formal de base normativa, que coloque as normas a screm obedecidas, e um sistema lógico-material, do qual se depreendem os valores socialmente protegidos, de forma que o último sirva de base para a interpretação do primeiro, e, conseqüentemente, para a elaboração de novas proposições jurídicas. Para ele, os requisitos de imputação objetiva são os mesmos daqueles propostos por Roxin: i) nexo causal entre a conduta e o resultado; ii) incremento do risco a um nivel socialmente intolerável; e iii) enquadramento da conduta no âmbito de proteção da norma penal; 
12. A teoria normativo-funcional de Jakobs, ao entender que a ação criminosa apresenta um significado apenas quando imersa em um determinado contexto social, também foi extremamente importante à teoria da imputação objetiva, pois introduziu o elemento da significação social da conduta como critério de imputação. Para ele, as normas são divididas em dois grupos: i) normas do entorno; e ii) normas sociais. As primeiras pertencem ao mundo do ser, não podem ser desobedecidas e são utilizadas para que a sociedade conheça os limites impostos pelo meio onde vive. Já as segundas pertencem ao mundo do dever ser, podem ser desobedecidas, e são utilizadas para a manutenção da atual configuração da sociedade, prevenindo condutas que a coloquem em risco. Jakobs defende que a função do Direito Penal, como última medida jurídico-coercitiva, é exatamente esta: a manutenção da atual contiguração da sociedade. Para o autor, a imputação objetiva requer a análise da conduta segundo quatro enfoques distintos: i) segundo a ocorrência do incremento do risco acima do socialmente permitido; ii) segundo o princípio da confiança; iii) segundo o principio da proibição de regresso; e iii) segundo o âmbito de competência da vitima;

13. Roxin, ferrenho defensor da teoria monista, coloca que o consentimento exclui sempre o tipo penal, pois ss encontra fundamentado na teoria liberal do bem juridico ligado ao individuo. Segundo ela, a principal função dos bens juridicos é o livre desenvolvimento do indivíduo, de forma que sua livre disposição pelo portador não implica a lesão destes bens. mas antes a sua expressão. O consentimento deve sempre excluir a tipicidade, pois o bem penal protegido é a liberdade individual, e não os bens jurídicos em si mesmos considerados. Além disso, o consentimento não pode ser tido como excludente de antijuridicidade, pois é um corpo estranho às causas de justificação. Para o autor, os principais limites à eficácia do consentimento são os vícios da vontade e a contrariedade aos bons costumes. A teoria de Roxin foi importante ao consentimento, pois introduziu a idéia de que o tipo penal pode ter como objeto de tutela a liberdade de disposição de bens pelo seu portador, mas apresentou grandes dificuldades ao estabelecer seus limites ante a esfera social, pois o paradigma monista não permite o conflito de interesses:

14. Jescheck, defensor do paradigma dualista, faz a diferenciação entre acordo (que exclui o tipo) e consentimento (que exclui a antijuridicidade). Os limites ao consentimento propostos pelo autor são: i) incidência sobre os bens individuais; ii) titularidade, pelo consenciente, do bem juridico protegido; e iii) não contrariedade aos bons costumes. Jescheck diterenciou-se dos demais dualistas por sua extrema rigidez quanto à eficácia do consentimento em relação aos bens de natureza híbrida e 
social, limitando demasiadamente seu âmbito de atuação e não permitindo a mobilidade de valores que a teoria da imputação objetiva é capaz de atribuir aos tipos penais. Jakobs, tal como o primeiro, também filiado à corrente dualista, diferencia consentimento de acordo. Para ele, o consentimento pode recair apenas sobre os bens intercambiáveis, disponíveis, que se modificam para o desenvolvimento da personalidade. Em relação aos bens que participam da constituição da pessoa, o consentimento não apresenta eficácia, exceto se outorgado por boas razões, especialmente para evitar a ocorrência de um dano ainda maior. Ao permitir a eficácia do consentimento mesmo em relação aos bens não intercambiáveis, quando em situações especiais. Jakobs em muito contribuiu para aliar o consentimento à flexibilidade que a teoria da imputação objetiva Ihe permite atribuir;

15. O consentimento é melhor ajustado ao Direito Penal, principalmente ao brasileiro, se analisado sob a sistemática da teoria da imputação objetiva, pois apenas ela introduz temas como o incremento do risco, a auto-responsabilidade da vítima e a significação social da conduta delitiva, permitindo que não o legislador, mas a sociedade, através de seu agir comunicativo, eleja quais tipos de bens o Direito Penal deve tutelar. Para que seja aplicado de acordo com os preceitos e com a mobilidade que a teoria da imputação objetiva pressupõe, o consentimento deve ser dividido em um consentimento-atipicidade e em um consentimento-justificação, tendo o primeiro lugar nos tipos que tutelam a liberdade de disposição de bens pelo individuo e o segundo nos tipos que tutelam os bens em espécie (bens em si considerados). Mesmo nos casos de consentimento-antijuridicidade, quando o bem tiver natureza eminentemente social, o consentimento pode ser eficaz para a exclusão ou diminuição da responsabilidade do agente, quando o interesse individual superar o social. Ao contrário do que defendem os doutrinadores brasileiros, de base positivista, o consentimento do ofendido deve apresentar um amplo âmbito de eficácia, pois se encontra intimamente ligado à dignidade da pessoa humana, ampliando a própria legitimidade do Direito Penal ao permitir que ele acompanhe o desenvolvimento social, captando seus valores vigentes.

São Paulo, janeiro de 2005. 


\section{Referências}

ANDRADE, Manuel da Costa. Consentimento e Acordo em Direito Penal . Contributo para a Fundamentação de um Paradigma Dualista. Coimbra: Coimbra, 1991.

CAMARGO, Antonio Luis Chaves. Imputação Objetiva e Direito Penal Brasileiro. São Paulo: Cultural Paulista, 2001.

CANCIO, Meliá, Manuel. Reflexiones sobre la "victimodogmatica" en la teoría del delito. Revista Brasileira de (iências ('riminais, São Paulo, v. 7, n. 25, p. 23-57, jan./mar. 1999.

Conducta de la victima e imputación objetiva en Derecho penal . Estudio sobre los ámbitos de responsabilidad de victima y autor en actividades arriesgadas. Barcelona: Bosch. 2001.

CASAS BARQUFRO, Enrique. La importancia del consentimiento en la teoría general del delito. Doctrina Penal teoria e práctica en las ciencias penales, Buenos Aires, v. II, n. 42, p. 213-230, abr./jun. 1998.

HASSEMER, Winfried. Fundamentos del derecho penal. Barcelona: Bosch. 1984.

JAKOBS, Günther; STRUENSEE, Fberhard. Problemas capitales del derecho penal moderno. Buenos Aires: Hammurabi, 1998.

Estudios de derecho penal. Madrid: Civitas, 1997.

JESCHECH, Hans-Heinrich. Tratacio de derecho penal: parte general. Barcelona: Bosch. 1981.

MARTÍNEZ ESCAMILLA, Margarita. La imputación objetiva del resultado - una primera aproximación. Revista de la Facultad de Derecho de México, México, v. 44, n. 193-194, p. 63-100, ene./abr. 1994.

MOLINA ARRUBLA, Carlos Mario. El consentimiento del sujeto pasivo de la infracción a la ley penal. Revista de la Facultad de Derecho y Ciencias Politicas da Ĺniversidad Pontificia Bolivariana, Medellin, n. 75, p. 11-38, out./dez. 1986.

PIERANGEli, José Henrique, O Consentimento do Ofendido na Teoriu do Delito, São Paulo, Revista dos Tribunais. 2001.

PRADO, Luiz Regis. Curso de Direito Penal Brasileiro. São Paulo: Revista dos Tribunais, 2002.

ROXIN, C. Derecho penal: parte general. Madrid: Civitas, 2001.

Problemas Fundamentais de Direito Penal. Lisboa: Vega, 1998. 
ROXIN, C. A Teoria da Imputação Objetiva. Revista Brasileira de Ciências C'riminais, São Paulo, v. 9 , n. 38, p. 11-31, abr./jun. 2002.

ROZO ROZO, Julio F. La eficacia del consentimiento del sujeto pasivo. Revista de la Academia Colombiana de Jurisprudência, Bogotá, n. 31 I, p. 107-133, jun. 1998.

SHEC.AIRA, Sérgio Salomão. A Responsabilidade Penal da Pessoa Juridica de Acordo com a Lei n. 9.605/98. São Paulo: Revista dos Tribunais, 1998.

SILVA SÁNCHEZ, Jesús-Maria. La consideración del comportamiento de la victima en la tcoría juridica del delito -- Obscrvaciones doctrinales y jurisprudenciales sobre la "victimo-dogmática" Revista Brasileira de Ciências Criminais, v. 9, n. 34, p. 163-194, abr. jun. 2001.

TOLEDO, Francisco de Assis. Principios Básicos de Direito Penal. São Paulo: Saraiva, 2000. 